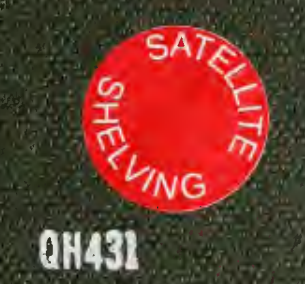




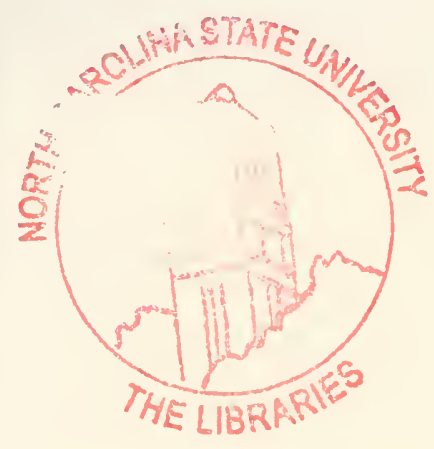

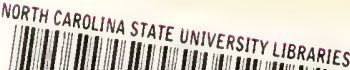


This book is due on the date indicated below and is subject to an overdue fine as posted at the circulation desk.

EXCEPTION: Date due will be earlier if this item is RECALLED. 



\section{THE GENETIC AND THE OPERATIVE EVIDENCE RELATING TO SECONDARY SEXUAL CHARACTERS}

By T. H. MoRgan

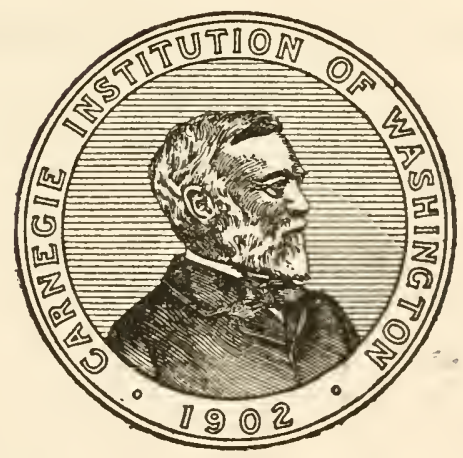

Published by the Carnegie Institution of Washington WASHINGTON, 1919 
CARNEGIE INSTITUTION OF WASHINGTON

Publication No. 285

PRESS OF GIBSON BROTHERS, INC.

WASHINGTON, D. C. 


\section{CONTENTS.}

\section{PART I.}

Introduction.

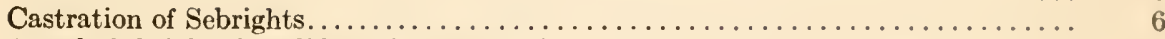

A male Sebright that did not become cock-feathered after castration.......... 10

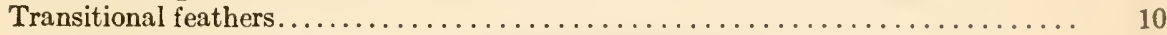

Castration of $F_{1}$ hen-feathered males from Sebright by game.............. 11

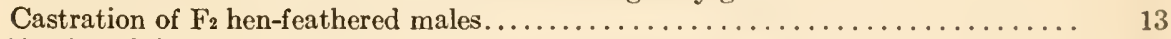

Hewitt's Sebright hen that became cock-feathered in old age............... 14

Heredity of hen-feathering. ................................... 14

Heredity of color in the cross between Sebright and Black-Breasted Game bantam. $\quad 17$

A. The $F_{1}$ birds....................................... 18

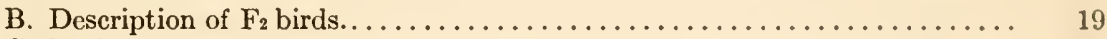

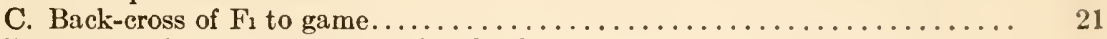

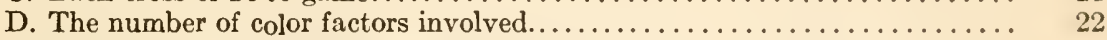

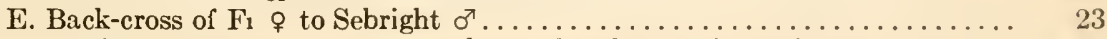

F. Review of the heredity of the color of the plumage in poultry .......... 23

Endocrine cells in ovary and testes of birds ....................... 32

Luteal-cells in the testes of the male Sebright.................... 34

Endocrine cells in the testes of mammals......................... 35

Cyclical changes in the interstitial cells in hibernating mammals............ 36

Hermaphroditism in poultry and the secondary sexual characters............ 37

\section{Part II.}

Darwin's theory of sexual selection.......................... 43

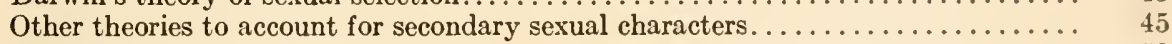

Display of the male........................................... 50

\section{Part III.}

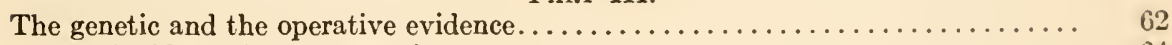

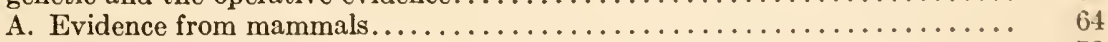

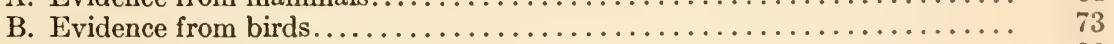

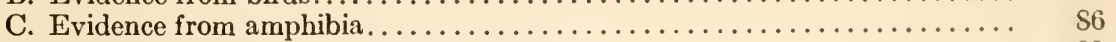

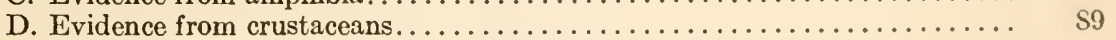

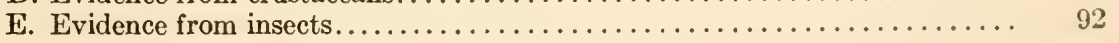

PART IV.

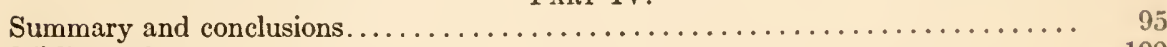

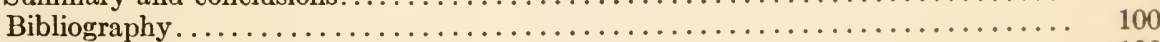

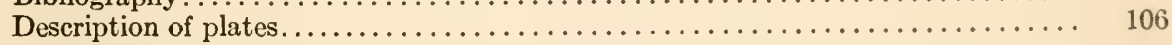





\section{THE GENETIC AND THE OPERATIVE EVIDENCE RELATING TO SECONDARY SEXUAL CHARACTERS.}

Br T. H. Morgan.

\section{PART I.}

There are a few races of poultry that have two kinds of males, one with the feathering of the ordinary cock, the other with the feathering of the hen. The Hamburgs and the Campines are perhaps the best known races of this sort. Convention amongst breeders, in certain countries, has determined that the cock-feathered bird shall be the standard, and at other times and places that the hen-feathered males shall be the show birds. In one breed, at least, viz, the Sebright bantams, the hen-feathered cock is the only known type. Cockfeathered Sebrights have never been seen, so far as I know. This breed is pure for hen-feathering. As shown in plate 1, figure 3, the male Sebright lacks the long, pointed saddle feathers at the base of the tail of the common cock, also the peculiar back and neck feathers (hackles) of the cock bird, as well as the male feathering on the bow of the wing. His feathers in these parts are almost exactly like those of the hen (plate 4, fig. 4). The long sickle feathers covering the true tail are also absent, although the two median ones sometimes occur in males of this race.

The Sebrights seemed excellent material for studying the heredity of this type of plumage in the male. In $1911 \mathrm{I}$ began to study this problem, and crossed Sebrights to Black-Breasted Game bantams. The latter race was chosen not only because the males have the typical cock-feathering, but also because the coloration of these birds resembles very closely that of the jungle-fowl, from which many, perhaps all, of our domesticated races have sprung.

In dissecting some of the $\mathrm{F}_{2}$ birds from this cross I noticed that the testis of the male was often more flattened than is the testis of the typical male bird, that it was often somewhat pear-shaped, and that frequently it was in part or entirely black. Recalling that male Sebrights are said to be often partially sterile, the idea naturally suggested itself that these birds are hen-feathered because the testes have assumed some of the characteristics of the ovary. It had long been supposed, and had been finally established by Goodale, that the presence of the ovary in the female suppresses her potential development of plumage, for when the ovaries of the hen are diseased or removed she develops the plumage of the male. This reasoning led me to try the experiment of castrating the hen-feathered males in 
order to see if they would become cock-feathered. The outcome was immediately apparent; the new feathers were those of the cock bird. While the "reasoning" that led to the experiment is open to serious question, nevertheless the "hint" furnished by the unusual condition of the testis led finally to the discovery that luteal cells were present in abundance in the testes of the male Sebright like those present only in the females of other breeds. Whether or not the shape of the testis of the Sebright, that is sometimes like that of the ovary, is connected with the unusual abundance of luteal cells in the testis I do not know. If so, then the hint that came from their shape was not so unreasonable as appears at first sight.

The birds first operated upon were adult $F_{1}$ and $F_{2}$ hen-feathered birds. The first one done by myself died, but a few, whose testes were removed by Dr. H. D. Goodale at my request, lived and changed to cock-feathered birds. Since then I have operated successfully on a number of $\mathrm{F}_{1}$ and $\mathrm{F}_{2}$ birds, as well as Sebright males. In these operations I have had throughout the assistance of Dr. A. H. Sturtevant and for two years the assistance of Dr. J. W. Gowen also. I wish to express my appreciation of their help and advice, for without it I doubt whether I could have carried out the work successfully. Since the main interest attaches to the Sebright experiments, they will be described first, although they were the last to be performed.

\section{CASTRATION OF SEBRIGHTS.}

Except for the similarities of the plumage, the male Sebright differs as much from the female as do cocks of other races. The rose comb is very large in the male, small in the female (plate 4, figs. 3, 4). The wattles also are longer in the male. The cock carries himself erect, as do the males of other breeds. His spurs are well developed and he shows the aggressive behavior of his sex. On the other hand, the shortness of the feathers on the back of the neck (the hackles), the absence of the pointed feathers on the back and rump, and the usual absence of long sickles and other tail-covert feathers make him hen-like. The detailed account of the feathers in these critical regions will be given when comparisons are made with the feathers of the castrated birds (plates 6 and 8).

Six males have been successfully operated upon and with one apparent exception have all given the same results. The birds were of somewhat different ages; they had been hatched about July, and were operated upon about November of the same year, when they were either half grown or had nearly reached maturity. At the time of the operation a few feathers were removed from different regions of the body, and the new feathers that regenerated in the course of 3 or 4 weeks showed all the characteristics of those that came in later to replace the juvenile or first adult coat. These regenerated feathers do 
not, therefore, call for special notice. All of the new feathers were in shape, pattern, and general coloration strikingly different from the original feathers, some of which were at first still present, the old feathers of course showing no change.

After completely molting, the appearance of the birds may be gathered from the photographs (plate 5) and from the colored drawings (plates 1 and 3 ). The male now has in all points the plumage of a typical cock-feathered male bird of other breeds. This is startlingly apparent in the hackle, back, rump, sickle, and tail-covert feathers. Instead of the laced feathers that are characteristic of both male and female, the whole upper surface of the bird appears reddish or yellowish, the black marginal edging of the feathers having disappeared. A detailed comparison of the feathers of the different regions will show how great a change has taken place. (See page 8.)

In plates 6 and 8 the feathers from characteristic regions of the normal Sebright and of the castrated Sebright are shown in pairs.

One of the first Sebrights that was castrated was a lighter bird than the others. Its lighter color was partly due to the narrower outer band of the laced feathers, (plate 6, figure 1,) and partly to the lighter color of the yellow-brown center of the feathers. The bird had a single comb, but as this crops up occasionally in some stocks of Sebrights, it need not be interpreted to mean that the bird was impure for color factors. After being castrated the bird changed over completely to cock-feathering and has remained in that condition for two or more years. As shown in plate 5, figure 2, the plumage is even more fully developed than in cock birds of some other breeds. The comb and wattles are, however, shrunken and pale, as in a capon. The bird is timid and scarcely or never crows. When killed (May 1919) no pieces of testes and no trace of testicular tissue at the old situs were found.

The details of the feathers are shown in plate 6 , figures 1 and $1 a$, where, in each instance, one of the old and one of the new feathers from the same region are placed side by side. The feathers on the head and hackle are yellow, even to the base. At the base of the hackle-the so-called cape-a few feathers have a small black tip. The feathers of the back are entirely yellow, except that where the fluff begins there is some dark pigment. The saddle feathers are for the most part all yellow, but a few have at the base, near the fluff, black on each side. The tail coverts are long, with a black margin at their tip. The tail feathers are long, mossy, and have a black tip. The wing-bow feathers are all yellow, except the black fluff at the base. The feathers on the crop are mostly yellow with black margin around the end. Those on the breast lower down are yellow with black tip and black fluff.

There was another Sebright operated upon at the same time that was a darker bird (as the original feathers show, plate 8 , figs. 1 to 4). It had 
a rose comb. The feathers that were plucked at the time of operation were replaced at once by new feathers of the cock-feathered type. The new feathers that came in as the old ones were molted were also cocktype, and the bird soon assumed the complete characteristic cockfeathering. The comb was shrunken as in castrated birds (plate 5,

\section{SEBRIGHT.}

Plates 6 and 8.

1. On the head (a) the feathers are small, dull black with lighter margin and reddish quill.

2. On the hackle $(b)$ the feathers are yellow bordered with black, expecially at the base, and at the tip outside of this border there is a narrow yellow border (broader at base). The border is absent at tip.

3. In the middle of the back (between the wings) the feathers are yellow with black margin at the tip. At the base there is some dark color.

4. The saddle is made up of typical laced feathers with black where the fluff begins.

5. The tail coverts are short; the upper ones, especially the short sickles, are slightly curved. The sickle feathers extend up only about half the length of the tail. They are yellow, laced, and have a black margin, tending to be lost at tip.

6. The yellow tail is short and erect.

7. The feathers on the wing bow are practically like those on the back, but shorter.

8. Over the crop and lower breast the feathers are laced.

\section{CASTRATE.}

Plates 6 and 8.

1. Feathers entirely yollow and more slender. Those on each side of the shrunken comb stand up from the head.

2. Hackles on upper part of neck have a black base with red tip. The outer edge, without barbules, is narrow, then broader than at tip. Farther down the neck the edge with barbules is yellow with a narrow black margin.

3. In the part of the feather with barbules there is a yellow center bordered by a broad black band, especially at base. In the part without barbules the feathers are yellow and more pointed. This region especially is deeper yellow than in the original Sebright.

4. Saddle consists of long, slender laced feathers, except at tip, which is red. Barbules are absent along edge of outer third of feather.

5. Tail coverts long, covering the tail as in cock birds of other breeds. The sickle feathers, especially the upper ones, are much curved, with black tips; the black margin is largely gone. The feathers are mossy, sometimes splotched (this is also sometimes noticeable in normal birds).

6. The tail feathers themselves are almost twice as long as in normal bird; the upper feathers are more curved.

7. The feathers of wing bow are like those of the back of the same bird, but shorter.

8. The crop feathers are narrower, with a wider black margin, and a few may be also entirely black. Feathers on lower breast much like those in normal, but a little more pointed.

figure 5). During the spring of 1917 it was noticed that the bird was going back towards the hen-feathered type, and by the end of the summer he was in the intermediate condition, as shown by the photograph and by the individual feathers (plate $8,1 b, 2 b, 3 b, 4 b$ ). The comb had begun to enlarge also. The bird was opened again (1918) and pieces of testis about as big as peas were found on one side. Evidently a piece of the old 
testis had been left behind and had regenerated. As it enlarged the new feathers were affected so that the plumage returned towards the normal type. The pieces of testis were removed and a few feathers plucked out. The new feathers that came in were typically cock-feathered, and, as the molting proceeded during the winter and spring, the bird became cock-feathered for a second time as shown in photograph (plate 5, figure 6) and by the feathers in plate $8,1 c, 2 c, 3 c, 4 c$. Here, then, is an excellent example of the connection between the gonad and the condition of the plumage. On opening this bird (May 1919) no pieces of testes were found. There was a very small whitish lump at the situs of the old testes, which, when sectioned, showed some glandular-like tissue, not in tubules, and no evidence of testicular tissue.

Three other younger Sebrights of the same stock were successfully castrated. They were hatched in June or July and castrated in November of the same year. They remained quite small birds, despite their elongation due to the long tail and tail coverts that they developed. One of these birds in his cock-feathered plumage is shown in plate 3, figure 1." One has died, the other two are alive and markedly cock-feathered, as shown in plate 6 , figure $2 a$. All three birds were dark red-brown, much more so than the two preceding cases, especially the first case. This color difference might be attributed to the earlier age of the three birds when operated upon, or to a more complete (or less complete) operation involving perhaps neighboring parts, or to the birds having a somewhat different genetic composition (i.e., modifying factors). . There is no special reason why the operation if performed early should have a different result on feathers that develop after the bird is of adult age. Goodale has suggested that there may be organs in the vicinity of the testis that have some influence on the kind of plumage produced, and if there are such organs they might be removed in one bird and accidentally left in another. It would not, however, be probable that the bird operated on at first had received one treatment and the later ones the other treatment. It seems to me more probable that the birds have come from different genetic strains, and that this genetic difference gives a more plausible explanation of the darker cock-feathered plumage. Goodale observed, for the first time I think, that the largest wing coverts of the castrated cock become longer. I looked, therefore, with some interest at the condition of these same feathers in the castrated Sebrights. As shown in plate 10 , figures $1,1 a$, these feathers are also longer and narrower in the castrated Sebright than in the normal bird.

The true tail feathers of the capon are said to be longer than those of the cock. This holds also for the tail feathers of all of my castrated Sebrights. Their true tail feathers are considerably longer than those of the normal male, as seen by pulling them out and comparing the two. Their length is concealed while on the bird by the excessively long coverts that appear after castration. 
In 1916 I operated on a Sebright male that lived for some months, but died in the summer of 1917. At the time of his death he had assumed a partial cock-feathering, as shown by the feathers in plate 9 , figure 3, 3a. Dissection showed that some of the testes had been left, and as is then to be expected, the change was incomplete.

\section{A MALE SEBRIGHT THAT DID NOT BECOME COCK-FEATHERED AFTER CASTRATION.}

One of the males that had been castrated with the others did not become cock-feathered even after a year. Taking for granted that the castration had been incomplete, the bird was opened, but as no pieces of the testes were to be found in the normal position he was killed and carefully dissected. There were no pieces of testes found in the normal situs. A small whitish patch of material from this region was cut into sections, but no testicular material was found in it. Then a large piece of the back from the region of the attachment of the testes was prepared, but as yet this piece has not been sectioned. Even were a small piece of tissue to be found, it would seem unlikely that it would suffice to hold back all indications of the cock-feathering, for after incomplete removal of the testis there are nearly always at first some indications of the lack of material. The most plausible view here is either that some other gland may have assumed, provisionally, the function of the missing testes, or else a detached piece has not yet been found. Glandular cells like the luteal cells of the ovary have in fact been described by some observers in other organs of the body. As yet I have not found time to make a thorough histological study of the tissues of this bird.

\section{TRANSITIONAL FEATHERS.}

In several birds new feathers had begun to develop at the time of the operation under the influence of the testicular secretion. After the removal of the testes, these feathers continued to grow and in the absence of the original conditions changed over to the other type. The outer end of these feathers shows the original or normal shape and color, while the inner end shows the new characteristics. Such feathers have been seen in nearly all of my castrated birds; a few from the Sebright will suffice by way of illustration. In plate 10 , figure $2 a$, four such transitional feathers are shown. In $a$ and $b$ two feathers from the hackle are photographed. The first $(a)$ had begun as a normal Sebright hackle feather, as seen in the condition of its tip; the rest of the feather is the same as the feather of the castrated bird. For comparison with this feather, two $(2 b)$ from the same bird are shown that began to develop after the testes were removed, $i$. e., at the same time as the change occurred in the former feather. At the time the latter 
feather $(b)$ had not yet completed its full growth. On the bow of the wing a few intermediate feathers, like the one shown in $2 a$, were present. (For comparison with normal and castrated feathers see those on plates 6 and 8.)

An intermediate feather from the back is shown in $2 a$. For comparison with the old feathers from the same region see plate 6, fig. 2 . An intermediate saddle feather is shown in $2 a$. For comparison with normal feathers from the same region see figure 2. A still later feather from the castrated bird is shown in $2 b$. The last was not yet complete when removed from the bird.

It will be noticed that the change after castration involves the color, the shape, and the presence and absence of barbules in those parts of the bird that are peouliar in the last respect. The transition in these characters is quite sharp-as sharp in fact as is compatible with the passage from one structure to that of an entirely different kind without any discontinuity of growth. Owing to the quickness of the response shown by the feather, it will be possible to study more in detail the length of time the secretion remains in the body of the bird after the testes have been removed.

\section{CASTRATION OF $F_{1}$ HEN-FEATHERED MALES FROM SEBRICHT BY GAME.}

Hen-feathering is dominant to cock-feathering. As shown in plate 2 , the $F_{1}$ male is almost as completely hen-feathered as is the male Sebright. There is a somewhat greater color difference between the $F_{1}$ male and $F_{1}$ female than between the Sebright male and female. Two $F_{1}$ birds were castrated for me by Goodale. At the time of operation, in the autumn of 1916, both birds were full grown, (plate 2, figure 1). After molting the old feathers, both birds appeared as shown in plate 2, figure 4. Each is completely cock-feathered. The plumage has also undergone a remarkable change in color. In general, the color change is from yellow and black to reddish yellow. The greatest change is over the upper surface. The sickle, covert, and tail feathers are well formed and have now become iridescent black. The breast has changed least of all. One bird died February 12, 1919. When opened there was found on the left side a small white lump; on the other side almost nothing. The lump was found to consist of testicular tubules with loose glandular cells on its walls.

The extent to which the change has taken place is best shown by comparison of individual feathers from identical regions-one before and one after the new feathers (taken out two years later) have come in (plate 7). The contrast between the old and new feathers of the hackle, saddle, back, and wing-bow are the most striking. In all of these the new feathers have become red on the exposed portion and the margin is free from barbules, as in the cock bird. The increase in size 
and change in shape of these feathers is remarkable. Equally great is the change in the tail-coverts that grade into those of the saddle at the base. The two median coverts or sickle feathers are longer than the tail and much arched. They are jet black with a purplish iridescence and with a yellow-red shaft. The tail itself has also changed; it has lost its stippling, and has become black like the coverts. The increase in length of the tail feathers is as remarkable as the increase in length of the coverts. A detailed account of these changes follows:

\section{$\mathrm{F}_{1}$.}

1. The head feathers are yellow with black base that shows through on the head.

2. The hackle feathers are yellow with black base (showing through on neck).

3. The red feathers of the back are penciled. There is a black band, especially around tip just inside of the margin.

4. The saddle feathers are much like those of the back, much stippled in center. The border is more distinct.

5. The tail coverts are similar to those of the hen.

6. The tail feathers are black, and with exception of the lower feathers they are partly stippled.

7. The wing-bow feathers are penciled like those of the back.

8. Feathers on crop yellow with black spot at tip; those lower down on breast have a bigger spot.

\section{CASTRATE.}

1. The feathers are entirely red.

2. The hackle feathers are entirely red.

3. Feathers of back are red except for black at base. Barbules absent at end and side. Tip pointed.

4. The saddle feathers are red with black base. They are long and pointed.

5. The coverts are blue-black, with brown shaft. They are long, pointed, and curved.

6. The tail feathers are black, not stippled, and have a black shaft.

7. The wing-bow feathers are red with black base.

8. Over the crop the feathers are orangebrown; on the breast they have the same color and a small black tip.

The $F_{1}$ bird from which the colored drawing (plate 2) was made and from which the normal $F_{1}$ feathers were pulled was lent to Dr. Goodale in the summer of 1917. The bird died in April 1918, and his skin was sent to me. He also had begun to change over to cockfeathering (plate 9, figures 2, 2a). Goodale recorded that the testis had dwindled to small bodies only about 10 by $5 \mathrm{~mm}$. This accounts for the change to cock-feathering. For comparison I have added a third set of feathers to the two former sets, showing the new hackle, back, saddle, wing, and bow feathers of this bird. The feathers show that the change is in the same direction as that shown by the castrated cock, but it has not gone so far in the direction of cockfeathering. The tail is still short and the feathers are black. The sickle feathers are not longer than the tail and are stippled. It is probable that this is the old tail whose feathers have not been molted since the testis dwindled. In fact, elsewhere the old and the new feathers are both present, showing that a complete molt had not taken place. The old feathers still present are practically like those of the original $F_{1}$ bird, showing that the change was of recent date, and due to the decrease in the testis which was probably caused by disease. 


\section{CASTRATION OF $F_{2}$ HEN-FEATHERED MALES.}

The $\mathrm{F}_{2}$ hen-feathered males from this cross could not be utilized until they had begun to assume the adult plumage, since before that time they were like the cock-feathered $\mathrm{F}_{2}$ males. Consequently, the operation is more difficult and more dangerous to the bird. A good many birds have died in consequence of the operation, but enough successful operations (five) were made to show what the color of certain types of hen-feathered bird would be when changed to cock-feathering.

A hen-feathered male (No. 292) that was darker than the $F_{1}$ malein fact, almost black, except for a yellow center in some of the dorsal feathers that were mossy or penciled- was castrated. The details of characteristic feathers may be gathered from the feathers in plate 7 , figure 2. A corresponding set of the new feathers after castration, $2 a$, are paired with the former. The castrated male in his new plumage is shown in plate 2, figure 3 . His dorsal surface is colored very much as is the same region in the $F_{1}$ bird, but the breast is very much darker, so that the bird as a whole presents a very different appearance from the $F_{1}$ castrated male. A very small white mass was found when the bird was killed in place of the old testis, composed, in sections, of a reticulated mass of cells that look like old broken-down follicles of testicular tubules with a few cell-layers lining the tubules. An $\mathrm{F}_{2}$ male (68) also had dark feathers (plate 3, figure 2, and plate 9 , figure 1 ). The castrated male in his new plumage is represented in plate 3, figure 3. Here again the upper surface is much like that of the last castrate, and also like that of the $F_{1}$ castrate. The breast has changed much less than the back; the centers of the feather are brown with a black margin and a black band at the tip. The exposed portion of the secondaries and the coverts are not so brown as in the last bird. The spurs of this bird were bent back, looking like the horns of a ram. When killed and examined, several small white pieces, that looked like pieces of testes, were found in the abdominal cavity near the old attachment of the testis. A histological study showed that these pieces contained tubular tissue apparently testicular, but without germ-cells.

Another $\mathrm{F}_{2}$ male (Band No. 221) was yellow in general color, the feathers being irregularly penciled. After castration (plate 3 , figure 4) the bird became red above and deep brown below; the tail and coverts were black.

A pale-yellow hen-feathered bird (No. 218) was also castrated. Here also the change was most conspicuous over the upper surface, not only in a greater depth of color than elsewhere, but in the shape, etc., of the feathers. On the breast the original yellow color remains, but is slightly deepened. When killed and opened (May 14, 1919), a few small, whitish pieces were found. When these were sectioned it was seen that they were made up, for the most part, of tubules look- 
ing like those of the epididymus and also a few testicular tubules. At the old situs there were some regenerated lumps, which in sections appeared to be loose glandular tissue. No germ-cells were present and the tissue just referred to may be old testicular tubules.

\section{HEWITT'S SEBRIGHT HEN THAT BECAME COCK-FEATHERED IN OLD AGE.}

Darwin records in Chapter XIII of Animals and Plants under Domestication a change that took place in an old female Sebright:

"Mr. Hewitt possessed an excellent Sebright gold-lace bantam hen, which, as she became old, grew diseased in her ovaria and assumed male characters. In this breed the males resemble the females in all respects except in their combs, wattles, spurs, and instincts; hence it might have been expected that the diseased hen would have assumed only those masculine characters which are proper to the breed, but she acquired, in addition, well-arched tail sicklefeathers quite a foot in length, saddle-feathers on the loins, and hackles on the neck-ornaments which, as Mr. Hewitt remarks, would be held to be abominable in this breed."

This is the only record I know of showing the change that takes place in the Sebright hen when the influence of her ovary is removed. There can be no doubt from the above description that she changes in the same way as does the castrated Sebright male.

Concerning the origin of the Sebright bantam Darwin states that the race "originated about the year 1800 from a cross between a common bantam and a Polish fowl, recrossed by a hen-tailed bantam, and carefully selected; hence there can hardly be a doubt that the sickle feathers and hackles which appeared in the old hen were derived from the Polish fowl or common bantam; and we thus see that not only certain masculine characters proper to the Sebright bantam, but other masculine characters derived from the first progenitors of the breed, removed by a period of about 60 years, were lying latent in this hen bird ready to be evolved as soon as her ovaria became diseased." To-day the problem appears to us in a somewhat different light, since the secondary sexual characters referred to by Darwin have simply been kept under for more than a hundred years by the secretion produced in the ovary of the hen (as in all breeds) and in the testis of the male Sebright.

\section{HEREDITY OF HEN-FEATHERING.}

In $1913 \mathrm{I}$ found that hen-feathering as seen in the Sebright is a dominant non-sex-linked character. A preliminary statement was given in the first edition of my book on Heredity and Sex (1913), which treated the character as a recessive one. This was a mistake due to a male having been obtained that was like the game race, which subsequent work showed must have been due to a sperm hav- 
ing been retained in the oviduct of the female during her isolation period. In the second edition published a few months later the mistake, having been found out, was corrected.

If one dominant suffices to produce hen-feathering, the $\mathrm{F}_{2}$ ratio would be 3 hen-feathered to 1 cock-feathered bird. The numbers found were 31 to 28 . This realized ratio departs too far from a $3: 1$ ratio to make it probable that the results are due to a single factor.

The $\mathrm{F}_{2}$ expectation for two dominants, both necessarily present to produce hen-feathering, is 9 hen-feathered to 7 cock-feathered birds. If the dominant factors are represented by $\mathrm{H}$ and $\mathrm{H}^{\prime}$ and their wildtype (recessive) allelomorphs by $h$ and $h^{\prime}$, the expected $F_{2}$ recombinations are given in the following table:

\begin{tabular}{|c|c|c|c|c|}
\hline & $\mathrm{HH}^{\prime}$ & $\mathrm{Hh}^{\prime}$ & $\mathrm{hH}^{\prime}$ & hh \\
\hline HH'. & $\begin{array}{l}\mathrm{HH}^{\prime} \\
\mathbf{H} \mathbf{H}^{\prime}\end{array}$ & $\begin{array}{l}\mathrm{Hh}^{\prime} \\
\mathrm{HH}^{\prime}\end{array}$ & $\begin{array}{l}h \mathrm{H}^{\prime} \\
\mathrm{HH}^{\prime}\end{array}$ & $\begin{array}{c}\mathrm{hh} \\
\mathrm{HH}\end{array}$ \\
\hline $\mathrm{Hh}^{\prime} .$. & $\begin{array}{l}\mathrm{HH}^{\prime} \\
\mathrm{Hh}^{\prime}\end{array}$ & $\begin{array}{l}\mathrm{Hh}^{\prime} \\
\mathrm{Hh}^{\prime}\end{array}$ & $\begin{array}{l}\mathrm{hH}^{\prime} \\
\mathrm{Hh}^{\prime}\end{array}$ & $\begin{array}{l}\text { hh } \\
\text { Hh' }^{\prime}\end{array}$ \\
\hline$h H^{\prime}$. & $\begin{array}{l}\mathrm{HH}^{\prime} \\
\mathrm{hH}^{\prime}\end{array}$ & $\begin{array}{l}\mathrm{Hh}^{\prime} \\
\mathrm{h} \mathrm{H}^{\prime}\end{array}$ & $\begin{array}{l}\mathrm{hH}^{\prime} \\
\mathrm{hH}^{\prime}\end{array}$ & $\begin{array}{c}\mathrm{hh} \\
\mathrm{hH} \mathbf{H}^{\prime}\end{array}$ \\
\hline hh. & $\underset{\mathrm{hh}}{\mathrm{HH}^{\prime}}$ & $\begin{array}{l}\mathrm{Hh}^{\prime} \\
\mathrm{hh}\end{array}$ & $\begin{array}{l}\mathrm{hH}^{\prime} \\
\mathrm{hh}\end{array}$ & $\begin{array}{l}\text { hh } \\
\text { hh }\end{array}$ \\
\hline
\end{tabular}

There are 9 classes containing both $\mathrm{H}$ and $\mathrm{H}^{\prime}, 6$ containing one or the other, and one containing neither $\mathrm{H}$ nor $\mathrm{H}^{\prime}$. The realized numbers, 31 to 28 , are in close approximation to $9: 7$.

In classifying the $F_{2}$ hen-feathered males, an attempt was made to divide them into two classes, viz, type 1 , hen-feathered to the same extent as the Sebright, and type 2 , intermediate between hen and cock feathering. The line between intermediate and cock-feathering is sharp, all the intermediates belonging distinctly to the hen-feathered group, but the line between the two subdivisions of hen-feathered birds is not sharp, and occasionally a bird is found that is difficult to place. These statements hold also for the $F_{1}$ birds, whose skins I now have. Five of these are classified as intermediates and one as completely hen-feathered. The difference between these two classes, then, is environmental or due to other modifying genetic factors, for which either the Sebright or the game is not pure. Under these circumstances it would not be profitable to attempt to find out (without additional evidence) what genetic differences, if any, lie behind the hen-feathered and intermediate-feathered birds in the $\mathrm{F}_{2}$ classes.

Concerning the back-cross ( $F_{1}$ by game) the expectation, for one dominant factor-difference, is 1 hen-feathered to 1 cock-feathered male. There were obtained 2 hen-feathered (intermediates) to 7 cock- 
feathered birds. The numbers are too small to be significant, taken by themselves. The expectation for 2 dominants, both essential to henfeathering, is 1 to 3 , and this is in agreement with 2 to 7 as found. It seems, then, more probable from the evidence of the $F_{2}$ and of the back-cross combined that there are two dominant factors present in the Sebright that make the male hen-feathered, and since the race breeds true to hen-feathering, both factors must be present in homozygous condition unless an undetected lethal destroys some of the classes. $^{1}$

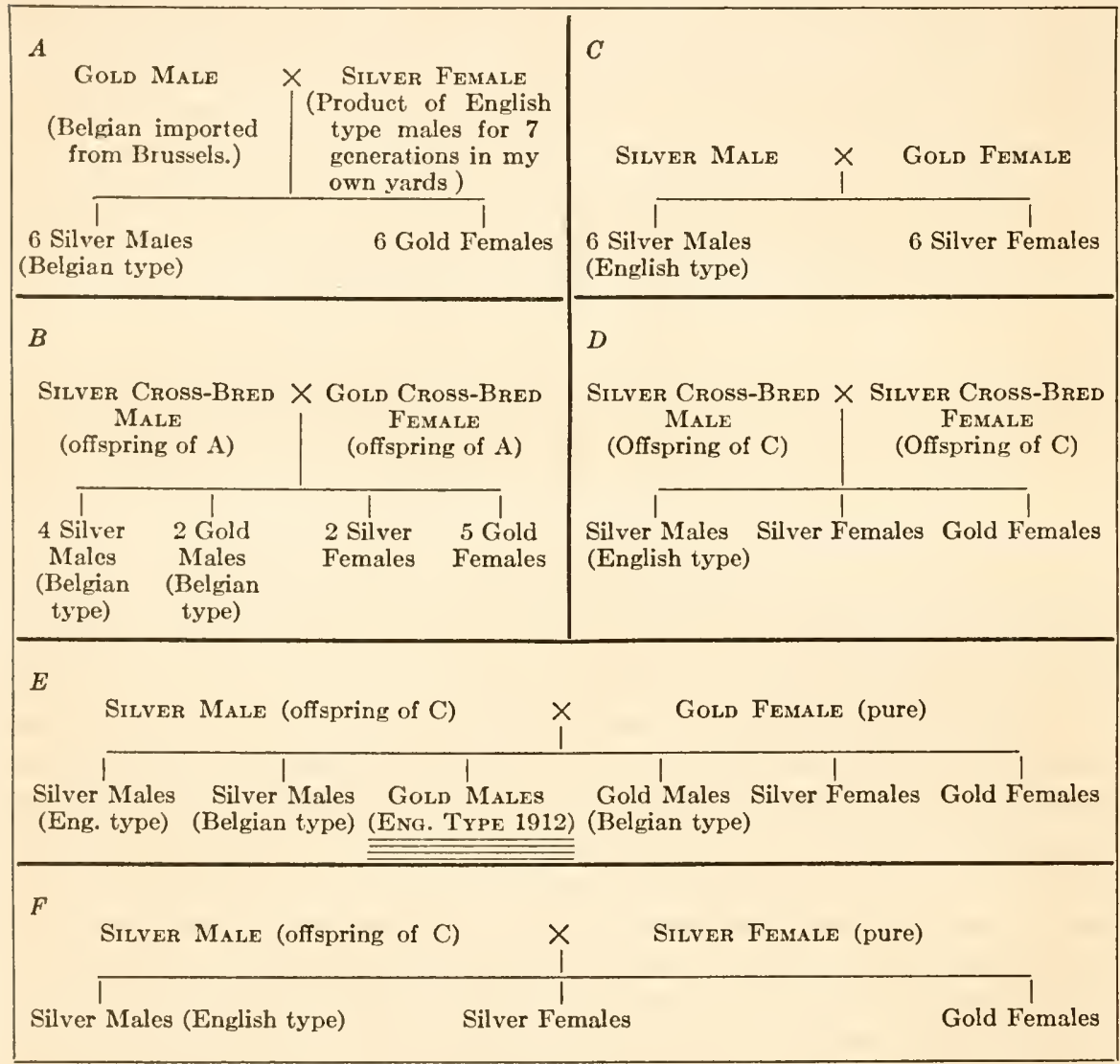

Smith and Haig have reported the following curious case of henfeathering. Smith had a breed of White Leghorns with cocks of two classes-those that assumed cock plumage at 6 months and those that are like the hens for 8 months, after which they slowly assumed the cock-feathering. The difference is hereditary and appears to segregate. Possibly this breed had one factor at least for hen-feathering that is effective for young birds, but not for older ones, or some of the

\footnotetext{
1 The expectation for 1 dominant and 1 recessive factor is so nearly the same as for 1 dominant alone that for the numbers obtained no difference between the two cases could be detected.
} 
birds pass through a stage when they produce an internal secretion that disappears later. But it is also possible, and perhaps more probable, that the young birds, not cock-feathered, have remained longer in the juvenile stage than the others, so that they might be said to be falsely hen-feathered.

The results published by the Rev. E. Lewis Jones in 1914, describing crosses between two breeds of Campines, one called Belgian (which has hen-feathered males), the other English (that has cock-feathered males), are summarized in the table on page 16 . They show the dominance of hen-feathering with some probability. The table given there is the original, to which the author has kindly added the numbers here prefixed to some of the classes. The numbers are not large enough in all cases to be satisfactory, but the dominance of the hen-feathering is, I think, apparent, as well as its non-sex-linked transmission. The golden female in $\mathrm{C}$ must have been English type, or at any rate heterozygous for English-type feathering, for if Belgian her sons would have been Belgian type.

Punnett and Bailey (1914) have published the result of a cross with hen-feathered Silver Sebrights and Hamburgs. The dominance of hen-feathering in the male is shown in the figures that illustrate their paper, but as the paper deals solely with the inheritance of weight the account of inheritance of hen-feathering was deferred to a later paper, that has not yet appeared.

\section{HEREDITY OF COLOR IN THE CROSS BETWEEN SEBRIGHT AND BLACK-BREASTED GAME BANTAM.}

The cross between the Sebright and the Black-Breasted Game bantam was undertaken primarily to study the inheritance of henfeathering. The Sebright was chosen, on the one hand, because this race is pure for hen-feathering, whereas in other races, such as the Campines, both kinds of males are known. The hen-feathered birds of such races are, I believe, frequently not pure for hen-feathering. The game race was chosen because the cock has the typical plumage of the wild bird, Gallus bankiva, and although his feathers are remarkably short, they show the characteristic cock-feathered type.

Only secondarily was the experiment concerned with color inheritance. The two breeds differ so markedly in coloration and pattern that the very complex results that appeared in $\mathrm{F}_{2}$ were to be expected. In addition to the differences involving hen-feathering versus cockfeathering, and Sebright plumage versus game plumage, the game is strongly dimorphic in the plumage, while in the Sebright the coloration of the two sexes is closely similar. But the castration experiments have shown that this difference is the result of hen-feathering in the Sebright cock, and that the race carries the same potential dimorphism as do other races of poultry. 
The game cock is shown in plate 1 , figure 1 , and plate 4 , figure 1 . The wattles and comb had been removed from the bird. The yellowred back and saddle are to be noted. The upper tail coverts and sickle feathers are black, as is the tail. These parts are shorter in the game than in other races, being one of the points selected for. The dorsoanterior edge of the wing is black, this color meeting across the middle of the back. Below this black area comes the red wing bow, followed by a double row of blue-black feathers. The exposed portions of the secondaries are brown, of the primaries black with green margin. The breast and entire lower surface is black. The legs are greenish, the bill black and yellow, the iris yellow.

The hen of the Black-Breasted game (plate 1, figure 2) is light yellowish-brown. The back, saddle, and wing coverts are golden brown, finely penciled with darker brown or black. The hackle is penciled; it has a yellow border (without barbules); the back is more brown, the forepart of the breast is salmon, the more posterior parts lighter salmon. The sides of the body under and below the wings are stippled gray.

The Sebright male is represented in plate 1, figure 3. Photographs of the male and the female are given in plate 4 figures 3 and 4 . Most of the feathers have a yellow center and a black border. Such feathers are said to be laced. The details of the different regions are shown in the feather plates, 6 and 8 .

\section{A. The $F_{1}$ Birds.}

The $F_{1}$ birds were remarkably uniform. The sexual dimorphism is slight, as a comparison of the male and female in plate 4 , figures 5,6 , will show. In the female the body feathers are penciled but very mossy, and this holds for the male too, except that in the hackle, back, and saddle, a change in color accompanies the change in shape, as seen in the individual feathers in the feather chart (plate 7, figure 1). If there are any sex-linked factors involved in the cross, we should expect different types of $F_{1}$ hens in the direct cross and its reciprocal, because in one case the $F_{1}$ hen gets her single $\mathrm{X}$ chromosome from one father, and in the other case, the reciprocal cross, from the other. Unfortunately no careful comparison can now be made, because the crosses were carried out in different years and the changes due to age may have affected the color sufficiently to obscure such slight difference that may have existed. But the effects of such factors, if present, are very small, since the birds seemed to be the same, regardless of the way in which the cross was made. In the $\mathrm{F}_{2}$ counts, although an attempt has been made to keep apart the birds obtained in the two crosses (i.e., the direct and the reciprocal crosses), it is very doubtful if the two groups show any significant differences. 


\section{B. Description of $\mathrm{F}_{2}$ Birds.}

All together there are 72 hens, 29 hen-feathered males, and 26 cockfeathered males, as shown in table 1 :

TABLE 1.

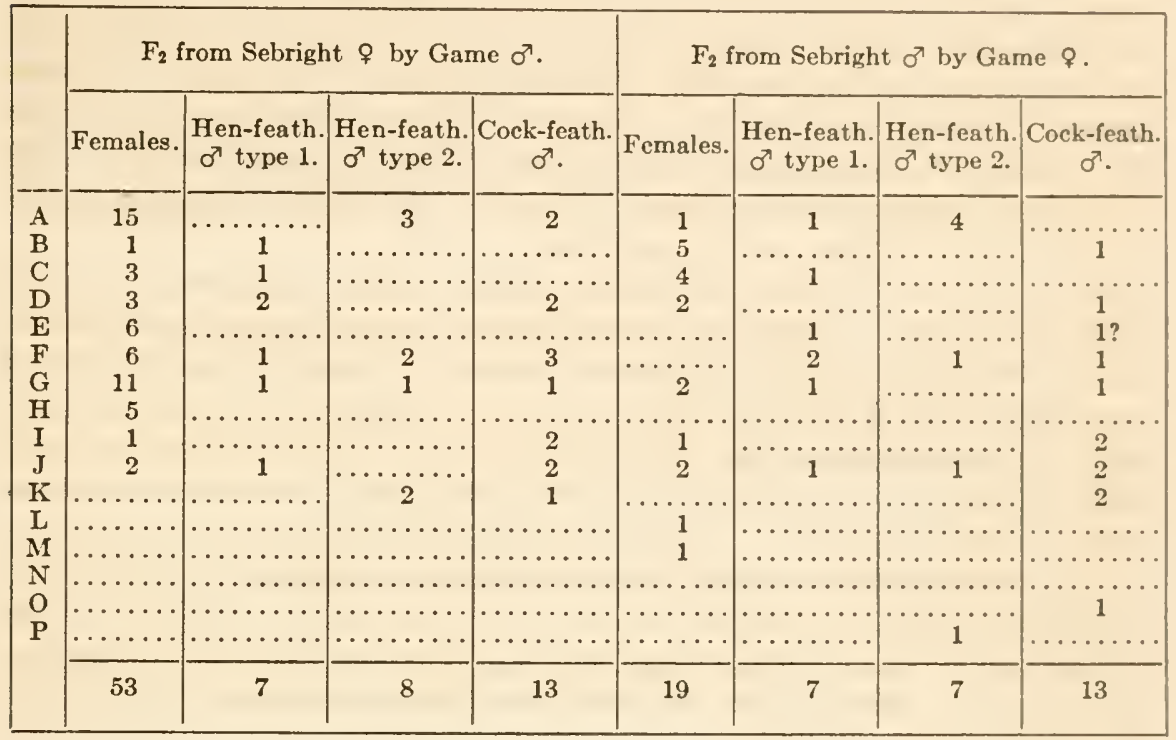

F2 Hens.

A. 8 females that are like $\mathrm{F}_{1} ; 7$ others resemble them below, but have stippled back and rump feathers ( 4 of these have yellow neeks, and 3 blaek necks like those of $F_{1}$ ). Here, then, are two or three subdivisions, or perhaps main elasses.

B. 1 female is very close to game, having the characteristic stippling above and salmon breast below. She is darker colored than the game females, therefore more like the Leghorn female.

C. 3 birds resemble the Sebright in plumage, but would not pass muster for real Sebrights.

D. 3 others have spangled breast feathers like the Sebright, but a great amount of stippling on the back.

$E$. 6 birds are yellow on breast, with stippled back.

$F$. 6 others are yellow, stippled birds with a little yellow penciling on the breast.

$G$. 11 black birds with some stippling on the back of the wing, and sometimes with traces of yellow in the hackle.

H. 6 other birds are dark, but not as black as the last. There is some stippling, especially on breast. The hackle is always striped. (4 of these have yellow necks above and below; 2 have dark necks.) The series of feathers photographed in plate 10, figure 4 , from a bird of elass $H$, show all gradations between a spangled and a barred condition. It is practieally certain that the barring seen here (as well as that under class $M$ ) is quite different from that of the Barred Plymouth Rock.

I. 1 yellow hen with a little black (as a band) on wings and tail.

$J$. 2 other yellow birds with a little black peneiling on the baek, the tail, and with long wing feathers.

\section{$\mathrm{F}_{2}$ MaLEs.}

K. 2 intermediate males with a black-splotehed red breast and blaek tail. The saddle is coarsely stippled. The corresponding male-feathered bird is red above.

L. A Sebright-like bird with black stippled feathers on back; the rest of the plumage heavily laced. Posterior part of breast and thigh black. The tail stippled. 
M. Yellow neck, the back, tail, and lower half of each secondary coarsely stippled. Posterior part of breast barred; cape and anterior breast penciled. The series of feathers photographed in plate 10 , figure 5 , from the breast of a bird in class $M$, shows all possible gradations from a penciled to a barred condition.

O. 1 cock-feathered, Red-Breasted game with somewhat stippled feathers. The lower half of each secondary is penciled (Hamburg type).

P. 1 intermediate male with yellow hackle that is black striped. He has a peculiar saddle, the general color of which is reddish brown. Each feather has a faint black edge, and is clear ycllow along shaft; the rest of the feather is finely dusted on a yellow background (plate 10, fig. 3). Breast feathers (in front part) are laced with an outer black band edged with yellow. In the posterior region of the breast the feathers are broadly laced. Wing-bow and coverts red, laced with black. The exposed edges of primaries and secondaries are red-brown, the covered parts black. The tail is black.

\section{Back-Cross Hens.}

A. Two dark $\mathrm{F}_{1}$ types. The breast is between stippled and penciled, the head is black.

C. (1) Sebright type. Very dark with much stippling. Some penciling on back. Breast dark; neck like that of Sebright.

(2) Sebright type like (1), but not such clear yellow. Secondaries and tail feathers and coverts stippled (with black tips).

(3) Yellow Sebright. Neck and breast yellow with black base and tip to feathers. Cape, breast, and wings (except bow) penciled to barred.

$C$. to $D$. (1) Pale yellow, breast spangled, back lightly penciled, tail same. Secondaries yellow and little stippled. Upper web of primaries stippled.

(2) Breast spangled, rest as in (1).

(3) Same as (2).

L. Dark Sebright. Back-feathers broadly laced and a little penciled. Neck black with yellow centers to feathers and yellow edges (reversed Sebright).

All of the preceding hens except A are in general Sebrights. The last three are pale stippled Sebrights.

\section{Back-Cross Hen-Feathered Cocks.}

$A$. One cock like $F_{1}$ male, but rather paler on back.

C. Four cocks. Light Sebrights, but spangled, in general, instead of laced. Feathers clear, not stippled.

$G$. One black.

L. Dark Sebright. Back and rump black. Feathers with narrow center, not stippled.

Q. Dark Sebright nearer to hen C (1). Thoroughly stippled with game tail. Neck and breast dark Sebright. Probably a new class nearer to (C).

$R$. Two cocks. Pale yellow instead of reddish, and much less black than are other yellows. No class of hens to match. ${ }^{1}$

In regard to color inheritance the preceding 19 birds are too few to add anything of significance to the other results, except that they serve to emphasize the dominance of the factors making for Sebright coloration. The hen-feathered cocks confirm the other results as to the dominance of the factor or factors in question.

There can be little doubt that some of these classes are complex. They almost merge into each other and in one part of the body individ-

\footnotetext{
1 There is one other bird, not given in the above list, that is pure Sebright except that his legs are yellow. Until I find out by further breeding of the Sebright stock whether yellow legs are present in it, this case must remain doubtful. On the basis of a two factor color-difference one Sebright (as to color) is expected in 16 birds, and one in 64 on a three factor basis. Some Sebrights had been raised along with the back cross, hence the possibility of contamination.
} 
uals may grade off into one class, in other parts into other classes. An almost continuous series of types might be arranged from black to pale yellow.

The difficulty of matehing the hen-feathered males to their genetic mates is almost insuperable. In table 1 an attempt was made to put these males with their respective females. The difficulty is, of course, greater for the cock-feathered birds, even with the castration evidence (that is too meager at present for the purpose), but a few of the males may be placed with certainty, and the rest guessed at.

One bird appears to be a hen-feathered game male resembling in many respects the female game, but darker and redder. There is more shafting on cape and wing-bow. The breast is unusually dark-salmon. The hackle is darker than is the game female. Upper wing-coverts broadly laced with black. (Plate 10, fig. 3.)

The occurrence of this hen-feathered jungle-fowl is so unique and the coloration of the bird so interesting that I have added to the plates three feathers of such a bird, viz., a stippled saddle feather, a feather from the back, a hackle feather, and a wing covert with stippled center and a black border. The neck hackle departs somewhat from the hackle of the jungle-fowl hen, but in the same direction as does the neck hackle of the Sebright cock from his hen.

Looking over the $\mathrm{F}_{2}$ group, the most noticeable thing is the large number of blacks ( $\mathrm{E}$ and $\mathrm{G}$ ), all of which are stippled. Probably the factor came from the game, because group $\mathrm{E}$ was present in the backcross as well as in $\mathrm{F}_{2}$, and because these black birds are always stippled. The yellow color (I and J) may have come from both, each breed having then a black factor that, as a pattern, covers over most of the yellow. It is difficult to distinguish penciling from stippling in the $\mathrm{F}_{2}$ yellows. Without figuring each of these types, their description in detail is not of much value. The skins will be deposited for reference in the Zoological Laboratory of Columbia University.

\section{Back-Cross of $\mathrm{F}_{1}$ to Game.}

As the back-cross of the $\mathrm{F}_{1}$ to the game might appear more likely to reveal the kinds of germ-cells present in the individual, the results from such a cross may be given before discussing the genetic data. If it were eertain that the "game" contained all of the recessive factors that are involved in the experiment, this method of testing the result would be ideal, but there is no way of determining a priori whether this is the case. The question will be taken up later. The presence of two kinds of males with corresponding but largely uncorrelated differences in their plumage makes their classification as a group impossible. It is simpler, therefore, to put the females into their classes first, after which the hen-feathered males may be expected to fall into the same groups (or nearly so), while the identity of the cock- 
feathered males, i. e., their class relationship can only be determined for the classes that resemble the $F_{1}$ and the $P_{1}$ birds. The $F_{2}$ henfeathered males can in part be further identified by means of the evidence that castration of these types affords.

Two of the $\mathrm{F}_{2}$ classes of hens can be identified in this back-cross, viz, (a) 4 hens like the $\mathrm{F}_{1}$ birds, (b) 3 hens like the game; (c) there were 3 other hens with plain yellow, $i$. e., not stippled backs. The upper surface was like that of the game female, but much lighter. The first two classes $(a),(b)$ might be again split into two types. There were only two hen-feathered males, one nearly like the $F_{1}$ male, the other blacker; they probably belong to different classes.

Of the 7 cock-feathered males, one was like the $F_{1}$ castrated males; another had a similar back, but a darker and differently marked breast; 2 were game-cock type; 3 were odd birds much like the game cock above except for absence of black, with reddish heads without any black. The males may be approximately classified as follows:

\begin{tabular}{|c|c|c|c|}
\hline & \multicolumn{3}{|c|}{ Back-cross $F_{1}$ ㅇ by game $o^{x}$. } \\
\hline & $\begin{array}{l}\text { Hen-feath- } \\
\text { ered } \sigma^{\top} \text {. }\end{array}$ & $\begin{array}{l}\text { Interme- } \\
\text { diate } \sigma^{\prime} \text {. }\end{array}$ & $\begin{array}{c}\text { Cock-feath- } \\
\text { ered } \sigma^{\top} \text {. }\end{array}$ \\
\hline \multirow{5}{*}{$\begin{array}{l}F(\text { or K) } . \\
(C) \ldots \ldots \\
B \ldots \ldots \\
\text { A......... }\end{array}$} & \multirow{5}{*}{ 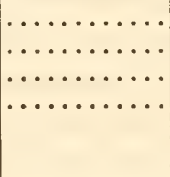 } & \multirow{5}{*}{\begin{tabular}{c}
\multicolumn{1}{c}{1} \\
1 \\
$\ldots \ldots \ldots \cdots \cdots$ \\
$\cdots \cdots \cdots \cdots \cdots$
\end{tabular}} & 1 \\
\hline & & & 2 \\
\hline & & & 2 \\
\hline & & & 2 \\
\hline & & & 7 \\
\hline
\end{tabular}

Four or five types may then be recognized in this rough grouping. None of the groups seem uniform and probably might be split again.

\section{The Number of Color Factors Involved.}

The theoretical expectation for two pairs of factors calls for 4 classes in the back-cross, but this assumes that the parent type used for backcrossing contains all (here 2) recessives. But this simple assumption can not be true in this case, for the $F_{1}$ bird would have been like the Sebright. On the 3 -factor assumption the expectation for the backcross is 8 classes, but this would apply only if the game were the triplerecessive form, which, again, it is not, as shown by the $F_{1}$ cross. But if the dominance of one or more of the Sebright color factors is incomplete, then either a 2 or 3 factor assumption might apply to the back-cross.

If only 2 pairs of factors are present we should expect to recover the game type once in 16 cases in $\mathrm{F}_{2}$. But, as will be shown, only 1 game was recovered out of the $49 \mathrm{~F}_{2}$ females. This result fits better with a 3 -factor assumption, for even with the small number in the back-cross the indications are that more than 4 classes are present. 
In the $\mathrm{F}_{2}$ birds at least 11 classes may be distinguished, and some of these appear composite. For 3 factors the maximum number of possible classes (including heterozygotes) is 27 . We can recognize at least $11 \mathrm{~F}_{2}$ classes amongst the females alone, and a few others are doubtfully present in the males.

In favor of the view that the heterozygous classes are here different from the homozygous, the following evidence may be utilized:

(1) The $F_{1}$ birds are entirely different from either parent and they are heterozygous for all the factor differences between the two types. The only alternative explanation for the intermediate condition of $F_{1}$ would be that each race carries one or more completely dominant factors. But the latter view is improbable because more of each parent type would then be expected in the $\mathrm{F}_{2}$ generation.

(2) In the $\mathrm{F}_{2}$ generation the $\mathrm{F}_{1}$ type is not as frequent as would be expected on the view that the heterozygotes could not be distinguished.

\section{E. Back-Cross of $F_{1}$ \& to Sebright $\sigma^{7}$.}

It is possible to add, now, while this paper is passing through the press (June 1919), the results of a back-cross of $4 F_{1}$ females to a Sebright male carried out during the summer of 1918. The birds being now mature their permanent colors are evident. Making the back-cross in this direction is much less advantageous than the reciprocal described above, because the Sebright contains most of the dominant color factors. The group of birds obtained appeared to be less variable in color than those from the other back-cross, and one can see at a glance that more of them approach the Sebright type; some quite closely.

All of the males are hen feathered, as expected. No evidence was found that two types of males exist, which would have been expected if the two types noted in $\mathrm{F}_{2}$ had any hereditary significance. If, then, as the $F_{2}$ results suggest, two factors for hen-feathering are present both are dominant, and no genetic distinction is found between individuals in which one or both of the dominaut factors are duplex or simplex.

There were 9 adult hens and 10 hen-feathered cocks. An attempt is made below to refer them to their corresponding $\mathrm{F}_{2}$ classes.

\section{F. Review of the Heredity of tile Color of the Plumage of Poultry.}

In poultry there are perhaps more different colors and color-patterns than in any other species of domesticated animals. The genetic work has advanced far enough to show that many of the differences depend on Mendelian factors. It is probable that, in addition to the main factors, there are many contributory, minor, or modifying factors that give the finer details to "show birds." 
It is generally supposed that the wild bird from which some at least of the domesticated races have come is Gallus bankiva of India and Indo-China, or else one or another of its subspecies. In any case, the wild type of coloration is approximately known, since the known wild races are colored alike in all essential respects. Even were the color of the wild type not known, the original plumage could be deduced with some degree of probability from the atavism that appears when some of the races are hybridized. It is interesting to find that many of the new plumage characters are dominant to the wild type. The same relation also holds rather generally for other characters of poultry, such as the comb, etc.

Amongst the uniform or single-colored races, the whites, blacks, reds, and buffs have been studied. Bateson and Punnett were the first to show that the white of the White Leghorn is dominant. They also showed that the white of the White Rose Comb bantams is recessive. Another white, that of the White Silky, is also recessive, but due to a different factor from the white factor of the Rose Comb bantams; for, when these two whites are bred together they give colored birds in the first generation. Hurst showed later that the white of the Leghorn is dominant over the black of the Hamburg and the buff of the Cochin. The dominance is often not complete, since tints of black or of buff or even patches of these colors may occur. The latter may be confined to the head, neck, and breast. The black plumage of the Hamburg is dominant over the buff of the Cochins, but incompletely so, as the black background may be marked and shaded with brown. Whether we are dealing here with one pair of factors, or two pairs, could only be determined by an $\mathrm{F}_{2}$ ratio; whether it is $3: 1$ or $9: 3: 3: 1$.

The blue color of the Andalusian is known not to be a simple color, but to be a fine mosaic of splashed white and black. The color is produced in birds that are heterozygous for splashed white and black, or at least for certain kinds of white and black. This relation was first demonstrated by Bateson and Punnett (1902 and 1905) and later Saunders (1906). It appears also from certain crosses made by Davenport that some of the whites (such as that of the Leghorn) and black (such as that of the Minorca) may at times also give some blue birds when crossed. Whether there are also other races with dominant white color different from that of the Andalusian white (and the same holds for black races also) or whether a special (recessive) white was present in this cross when the blue appeared, was not made out by Davenport.

Lippincott has recently studied the Andalusian cross and obtained essentially the same results as his predecessors. He calls attention to an interesting fact in the splashed whites, namely, that the color splashes are blue when thay are found in those parts of the body where the color is blue in the Andalusian. Although the Andalusian is always 
spoken of as a blue bird, the hen only is entirely blue, while the male is black above and blue below. The splashes on a white male correspond to the black and blue of the Andalusian male, and are black if above and blue if below.

Lippincott found also that the blue birds differ from the black in two characteristies, viz, in the blues the pigment is in larger masses, $i$. $e$., it is more clumped, leaving more white between the clumps than in the blacks, and in the blues the pigment is absent in the extremities of the barbules. If the clumping and the condition of the barbules are treated as separate entities, each gives a 3:1 ratio. Lippincott concludes, therefore, that the Andalusian cross is a 2 -factor case. If each of these characteristics was independent of the other in the sense that some birds had clumped pigment and others deficiencies in the barbules, then one might conclude that he was dealing with a 2 -factor case; but if these two characters are only different aspects of the same gene, and when one is present the other is also, the situation is not different from those that are very common, viz, two or more effects produced by the same genetic factor.

Davenport has recorded results of crossing several breeds of different colors (1906 and 1909). The white of the Leghorn was found dominant to the black of the Minorca breed, although the hybrids, "at least the females," had some black feathers. This white was also found to be dominant to the mottled Houdan and to the "Red-backed game." On the other hand, a male Tosa with wild-type plumage by recessive White Cochin female gave "barred" males in $F_{1}$; the barring coming in, no doubt, from the Cochin and although not at the time recognized by Davenport as sex-linked inheritance, the statement that barring is "associated with maleness" (as already pointed out by Darwin) indicated that the barring that appeared within the cross was probably the sex-linked barring shown by other breeds.

In Davenport's cross of White Leghorn by Minorca two blues appeared (as stated above), indicating that the same factors were here present that in the Andulusian white and black strain gives the same result, ${ }^{1}$ but why only some of the $F_{1}$ appear as blue, while others are not blue, is not yet made clear, unless two factors for white were present. White of the Leghorn breed was found not to be as completely dominant over buff as over black. Black was found dominant over the wild-type (Black-Breasted game), but red is present in $F_{1}$ birds also to some extent in those places where red is found in the game. Lacing, as shown by the Dark Brahma, is dominant to the plumage of the Tosa. Penciling also is said to be dominant, as shown in females of the cross between the Dark Brahma and 'Tosa fowl.

In his later paper (1909) Davenport gives fuller information in regard to some of the $F_{1}$ cases reported in his first paper, as well as the

1 Provided that the blue classification was based on the adult plumage and not on down color. 
$\mathrm{F}_{2}$ results. Thus, in the cross of Silky to Minorca, that gives black $\mathrm{F}_{1}$ birds, the $\mathrm{F}_{2}$ count gave 210 black, 57 game, and 95 white-approximately the expectation for two pairs of factors, one of them giving white $(9: 3: 4)$. Silky by White Leghorn gave white $F_{1}$ 's, but the males developed red on the wing bow and saddle when they became mature, and the female a faint blush of salmon ("red") on the breast. In $\mathrm{F}_{2}$ there were whites, games, and blacks, approximating to expectation for three pairs of factors, one being a dominant white (52:9:3). Silky by Buff Cochin gave a washed-out buff, but with the jungle coloration partly developed in the tail (black) and hackles and wing bow (redder buff). Davenport represents the Buff Cochin as having lost the jungle patterns and coloration, while the Silky retains it. The heterozygous condition of the genes for the wild-type color in $F_{1}$ is made responsible for the part development of color. The White Silky is represented as carrying the factor for black $(\mathrm{N})$, hence in $\mathrm{F}_{2}$ both black and gamecolored birds are expected and they were obtained. When Black Cochin is crossed to Buff Cochin, the $F_{1}$ males are in general like the game (black and red) while the females are black (except for some red on the hackle). In this case Davenport represents the Black Cochin as showing a factor for jungle-fowl pattern, but lacking the color that is assumed in his other formulæ to go with this pattern. What is meant by this change is not quite clear to me, unless Davenport supposes there is an independent factor for the jungle-fowl pattern which may be filled in by other colors determined by other factors. But were there enough $F_{1}$ birds to exclude the possibility that jungle-fowl birds would not appear in this cross?

Davenport has reported a cross between a female White Cochin and a male Tosa (wild type) from which the daughters were Tosa, except that the shafting was broadened, and the saddle feathers and proximal secondaries were obscurely barred (black and buff); the sons were also like the Tosa, but every feather was repeatedly barred (see above). In $\mathrm{F}_{2}$ there were 15 white, 25 game, and 16 barred birds. Davenport concludes that "barring is clearly heterozygous and confined to the male sex," and in a footnote he adds that the sex-linked barring factor of the Plymouth Rock is different from that of this Cochin-Tosa cross, but Goodale informs me that the barring that appeared in this cross is probably the same as that in Barred Rocks.

As pointed out, an interesting feature of color inheritance in poultry is the large number of cases of sex-linked inheritance. It might seem probable here, as in the case of Drosophila, that this is due to a wellrecognized difference between sex-linked and autosomal characters, namely, that a recessive mutation in one of the sex chromosomes of a sperm-cell of the male bird will have a chance of showing its effect immediately if that sperm-cell unites with an egg without a $\mathrm{Z}$ to form a daughter, whereas it would not immediately show up in the offspring 
if the mutation were autosomal. ${ }^{1}$ In consequence the recessive mutant would have a greater chance of being observed and selected if it appeared in a sex chromosome. But dominant sex-linked characters, however, have the same chance as dominant autosomal ones and the question turns therefore on the kinds of characters shown in the cross.

The first indication of sex-linkage in fowls was furnished by evidence that Spillman published in 1903 on information supplied by poultrymen-information that has been proven subsequently to have been accurate. Spillman pointed out clearly the similarity between the facts he quoted and the then known cases of sex-linkage in the canary and in the currant moth. The case referred to by Spillman was a cross between Barred Plymouth Rock and Black Langshan. Goodale and I repeated the cross, using both Plymouth Rock and American Dominques, publishing the results in 1912. In addition to the $F_{1}$ results evidence was obtained for the $\mathrm{F}_{2}$ generation. The theory was also tested by back-crossing. The results of such a cross that are typical for all cases of the sort are briefly as follows: Plymouth Rock cock by Langshan hen gives $F_{1}$ barred sons and barred daughters. These inbred give $\mathrm{F}_{2}$ barred cocks and barred and black hens $(2: 1: 1)$.

In the following schemes the sex chromosomes are represented by $\mathrm{Z}$ and $\mathrm{W}$, while the exponents stand for the factors involved, viz, B for barred and b for not-barred, which here means a black bird.

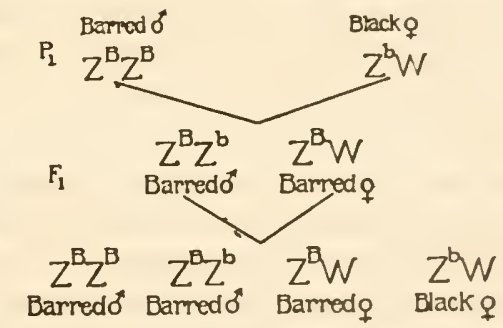

In the reciprocal cross, a black cock was mated to a barred hen. The sons were barred, the daughters black $\left(\mathrm{F}_{1}\right)$. These inbred gave $\left(\mathrm{F}_{2}\right)$ barred males and females, black males and females in the ratio of $1: 1: 1: 1$. The chromosome scheme of inheritance is as follows:

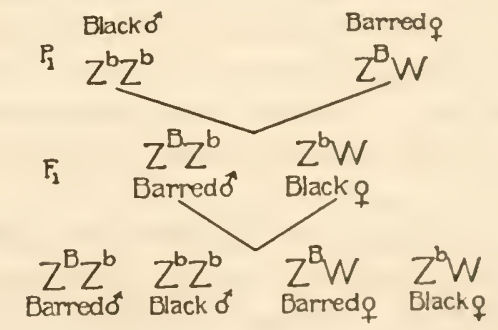

\footnotetext{
${ }^{1}$ If the recessive mutation occurs first in the $\mathrm{Z}$ chromosome of an egg of the female it will not appear in the next generation; then if it has passed into a male, half his daughters will show it. The single factor-pair involved is carried by the sex chromosomes Z Z.
} 
One back-cross test consists in mating the $F_{1}$ barred males $Z^{\mathrm{B}} \mathrm{Z}^{\mathrm{b}}$ (from both crosses) to a pure black female. The expectation is for equal numbers of barred and black males and females, and the result was realized. The $\mathrm{F}_{1}$ barred hen of the first cross $\left(\mathrm{Z}^{\mathrm{B}} \mathrm{W}\right)$ back-crossed to a black cock is expected to give only barred males and black females, and this result also was obtained. The explanation of the last cross, based on the sex chromosomes, is as follows:

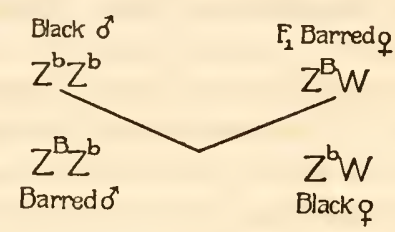

Before these experiments were finished Goodale had made other crosses involving the barring factor, and had obtained results that showed the sex-linked inheritance of this factor (1909). For example, he crossed Buff Rock male (not barred) to white Plymouth Rock females. The sons were barred and the daughters not barred. The reciprocal cross gave barred sons and daughters. A White Rock male (carrying barring) mated to a Brown Leghorn female gave barred sons and daughters. Reciprocally, the chicks were of two kinds as to their down, viz, black chicks and chicks with the down pattern of the barred rock. All these results with Barred Plymouth Rocks show that they carry a sex-linked dominant factor for barring. Its wild-type allelomorph would be game-color (jungle-fowl), but since, when the dominant barring is absent in some of the individuals in these crosses, they are black, it would seem to follow that another dominant factor, one for black, that is not sex-linked, is also present.

Pearl and Surface have also carried out crosses with Plymouth Rocks on a much larger scale. Their results conformed in every way to the foregoing. They crossed Barred Plymouth Rocks and Cornish Indian games. The plumage of the male of the latter race is black with dark red on the back and wing-bows; the females are also black laced with mahogany ground-color on back, breast,wing, and tail coverts. When the male game is mated to the barred hen the sons are barred and the daughters are black. In the reciprocal cross both sons and daughters are barred. The back-cross tests conformed to expectation. The results were the same as those already stated above for the Langshan-Rock cross.

Sturtevant crossed Columbian Wyandottes and Brown Leghorns. The $\mathrm{F}_{1}$ sons were alike, whichever way the cross was made. They were fairly typical Wyandottes, which race carries therefore more of the dominant plumage characters (two or three?). There were two types of daughters, depending on the direction in which the cross was made. 
When the father is Wyandotte, the daughters are like him (except for stippling of the Leghorn type). When the father is Brown Leghorn the daughters are somewhat stippled red birds. In the former case the daughters getting their $\mathrm{Z}$ chromosome from their Wyandotte father resemble him; in the latter case the daughters getting their $\mathrm{Z}$ chromosome from their Leghorn father look more like him. Their failure to look exactly like him must be due to autosomal factors derived from the Wyandotte mother that dominate other autosomal factors from the father.

Hagedoorn crossed Black Breasted Game bantams (like those used in my Sebright crosses) to Brown-Breasted bantams. In the latter the black breast feathers of the male are bordered by lemon; the hens are nearly black. Black-breasted male to "brown-red" female gave both black-breasted sons and daughters. In the reciprocal cross all the sons were black-breasted (like the mother) and all the daughters were brown red like the father. Evidently the factor here for Brown Breasted game is sex-linked and recessive. In this case the new mutant sex-linked character is recessive to the wild type.

Davenport (1912) crossed Brown Leghorns to Dark Brahmas. In the cross and its reciprocal all the sons are alike. Two dominant sexlinked factors were found, ${ }^{1}$ viz, the white background characteristic of the Dark Brahmas and the red upper wing-coverts (and back) characteristic of the Brown Leghorns. On the other hand, the daughters differ in the two crosses, in each case resembling their father in their hackle color.

When two sex-linked characters are involved in a cross it is possible to determine by suitable matings whether an interchange between the chromosomes that bear them has taken place. In the case of the sex chromosomes only one sex, the male, has both like chromosomes, viz, ZZ, and we expect from analogy with the Drosophila work that crossing-over would be found between the sex chromosomes only in the male. Goodale has recently (1917) made the important discovery that in poultry crossing-over takes place between the sex chromosomes (ZZ) in the male, but not in the female (ZW or ZO). This relation, therefore, is the reverse in birds and flies, for, in the one, crossingover takes place in the female and in the other in the male. Whether this difference extends also to the other chromosomes in birds as it does in flies is as yet not known.

Several years ago some crosses between gold and silver Campines were reported by Rev. E. Lewis Jones. The results are consistent with the view that a sex-linked factor pair is responsible for this difference in color, although the author does not apply this view to his results. The results may be seen in the table on page 16, to which Jones has

1 One may be either sex-linked or sex-limited so far as the evidence goes. 
prefixed the number of individuals. The cross also involved henfeathering versus cock-feathering, which appears here (as in other cases) to be a non-sex-linked dominant factor. As stated above there are in the results a few apparent inconsistencies with this interpretation, due possibly to heterozygous females having been used in the crosses.

Lefevre crossed Silver Spangled Hamburgs and Brown Leghorns. The spangling was found to be a sex-linked dominant factor. A spangled cock bred to a Leghorn hen gives spangled sons and daughters; a spangled hen by a Leghorn male gave spangled sons and not spangled daughters. The daughters do not transmit spangling. Other factors may obscure the results, especially factors for black, or the localization of the pattern. Lefevre says "it would seem probable that multiple factors for black, introduced by the Brown Leghorns, are present, and that these factors may have a cumulative effect, with the result that pigmentation is developed to varying degrees of extension." Whether the factors for black spoken of as coming from the Leghorns are dominant wild-type factors that have mutant allelomorphs in the Silver Spangled Hamburg is not entirely clear from the quotation.

Baur gives in his Introduction to the Study of Heredity (1914, pp. 202-203) some results (unpublished) that Hagedoorn had obtained by crossing gold and silver races of Assendelver birds. The factor is sex-linked and is no doubt the same factor reported by Jones for gold and silver Campines and by Sturtevant for Columbian Wyandottes. Silver dominates gold and the sex relations are the same as those already reported by others for poultry, viz, the male is $\mathrm{ZZ}$, the female ZW. Gold hens by a heterozygous silver ${ }^{1}$ gave 162 silver cocks, 163 silver hens, 168 gold cocks, 160 gold hens, expressed graphically ( $g$ for gold, $s$ for silver):

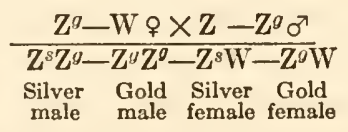

When a silver hen was united to a gold cock there were 246 silver cocks and 243 gold hens-crisscross inheritance.

\section{Summary.}

From the standpoint of the Brown Leghorn type representing the wild type, the following colors and patterns represent dominant mutations from that type:

White of White Leghorn.

Silver of Dark Brahma.

Black of Minorca.

Lacing of Brahma.

\section{Dominants.}

Barring of Plymouth Rock. Black (?) of Plymouth Rock. Buff (or red).

\footnotetext{
I No mention is made by Baur that a heterozygous male instead of a pure silver male was used, although the male is made heterozygous in the formulæ.
} 
Each of these (in heterozygous condition of course) is dominant; in some cases completely so, in others incompletely dominant. At three different loci in the sex chromosome a dominant mutation has occurred; at three loci in other chromosomes dominant mutant changes have also occurred.

Recessives.
White of Rose Comb bantam.
White of Silky.

Whether the recessive white that is sometimes found in dominant White Rock stock is different from both of the other recessive whites is not known. There are, then, 5 or 6 recessive characters that are not sex-linked and 1 recessive sex-linked character.

Owing to the relatively large number of color dominants in poultry, some unnecessary confusion has arisen concerning the relation of the dominants to the wild type, and especially to other mutant characters to which they are said to be dominant, in the sense, however, of being epistatic. An imaginary example will illustrate this. For example, if at some locus in the wild type a mutation occurred that gave a dominant black ( $i$.e., a black that shows up when one gene for it is present) and at the same time this black also showed up even when other recessive mutant characters were present in homozygous form, then $F_{1}$ birds would be black when black is crossed to such pure recessive stocks. Such cases have indeed been described as dominant, but a knowledge of $\mathrm{F}_{2}$ would have shown at once the error of such a system. For, if black had been a real dominant, the $\mathrm{F}_{2}$ would have given 3 blacks to 1 of the other type (such as the wild type), but if the case were one of epistasis, then there would have been $9: 3: 3: 1$ classes in $\mathrm{F}_{2}$ (or some modification of that ratio). In this sense, then, epistasis may be defined as a result that appears when one member of the pair of genes produces its effect regardless of the constitution of the individual with respect to another gene (or other pairs of genes). It is curious at least to note that in the case of dominant white the term epistatic has been much less often used than in the case of black. Theoretically the two situations are exactly alike, but because black could so obviously conceal things beneath it, while white is not thought of as doing so, it seemed "natural" to make such a distinction. In reality it is not a question of covering up at all, but a ease of a dominant character (white or black) preventing other colors from appearing.

In the case of recessive white the situation is somewhat different and no one, so far as I know, has gone so far as to speak of such a white as epistatic, although when the animal is white it certainly hides, when completely effective, all the other effects of color-producing factors, but allows them, to "show through" in some of the cases. This means not that they do "show through," but that they only develop 
to a "lower" degree. The difference between dominant and recessive whites rests on the fact that in one case one member of a pair of factors gives white and in the other both members are necessary. But obviously such a distinction is not important, and if it were worth while the case might be argued for recessive whites being also epistatic. The whole tangle goes back to a false interpretation of presence and absence of characters and presence and absence of factors. As I have gone over this ground recently in my paper on the Theory of the Gene, I need not repeat here what I tried to make clear there.

\section{ENDOCRINE CELLS IN OVARY AND TESTES OF BIRDS.}

The occurence of gland-like cells with an internal secretion in the ovary and testes of fowls has been described by a number of writers and denied, at least for the testes, by others. The work of Boring and Pearl has done much to bring this question to a satisfactory solution, for they have tested out and made use of the best reagents that their predecessors had discovered and have used a much greater amount of material. As they have reviewed very fully the literature of the subject, it will not be necessary to go over the ground again in detail.

In the follicles of the ovary there are present, according to Boring and Pearl, groups or nests of cells lying among the connective tissue of the inner theca. The cells are about three times as large as the ordinary connective-tissue cells of the ovary. The cytoplasm is clear and vacuolated, "only occasionally containing a few acidophile granules which stain with the fuchsin in Mallory's stain or the eosin of Mann's stain, while the real interstitial cells are crowded with granules."

When the egg is set free from its follicle, the latter collapses and the rupture becomes closed. A mass of cells collects in the center of the collapsed structure which develop yellow pigment. The cells, lying in the puckered edge of the follicle, may also develop such yellow color. The cells that produce the yellow pigment come from the nests of cells that lay originally mainly in the theca interna. Either by migration or by division they come to fill up the central cavity. The yellow substance in the cells is not fat, since it does not dissolve in the clearing oils, nor can it be protein, for it does not take acid stains as normal secretion granules of protein. It does not dissolve in $\mathrm{HCl}, \mathrm{HNO}_{3}$, or $\mathrm{H}_{2} \mathrm{SO}_{4}$, nor in strong $\mathrm{KOH}$, although the latter turns the pigment a bright red color. Many other substances were also tried by Boring and Pearl, but none of them dissolved the yellow pigment, which reacts in this respect in the same way as does the yellow pigment in the luteal cells of the mammal. The similarity in the nature of the pigments in the two cases is an argument in favor of the view that the cells that produce the pigment are the same in both groups. In the 
mammal the yellow corpus luteum is a large, gland-like organ that develops after the ovum is discharged; in the bird there is also a yellow spot on the ovary, due to the pigment in the collapsed follicle, but it is smaller and much less conspicuous than in the mammal. The evidence concerning luteal cells in the testes of the bird is conflicting. One of the difficulties in the situation is the identification of the cells, which are sometimes regarded merely as the general connective-tissue stroma of the testis that is undoubtedly present; at other times special secretory cells are discerned embedded in the connective tissuc, as individual cells or in islands. Boring states (1912) that in newly hatched chicks about half of the tissue of the testes is interstitial connective tissue; the other half consists of tubes or cords whose principal function is the development of the germ-cells. In the paper of 1912 Boring reached the conclusion that there are no "interstitial cells in the testes of the domesticated chicken in the sense that this term has been previously used," and states that no evidence has been found that an internal secretion of any kind is formed by any cells of the interstitial tissue.

It is not necessary to discuss whether or not connective-tissue cells are present in the testes of birds, for is it generally conceded that they are found at least in certain stages, but it is important to look into the question as to whether among these interstitial cells there are others that have an endocrine function. Mazzetti gives pictures of such gland-cells between the seminal tubules of the cock bird, but says that they are rare, "even though this bird has very marked secondary sexual characters" (Boring and Pearl). It may be remarked parenthetically that if they had been more abundant the bird might have had no secondary sexual plumage since it will be pointed out below that such glandular cells may have as their special function the suppression of these characters.

According to Des Cilleuls, interstitial cells are first found in males about 30 days old and at this time the secondary sexual characters put in their appearance. If, as will be shown in the sequel, he means by interstitial cells the endocrine cells that suppress the development of the male plumage in the female, the appearance of these cells at this time would be significant; but if he implies that their occurrence in the male incites the development of the secondary sexual characters, his interpretation is open to serious doubt. Reeves found interstitial cells in testes of cocks $3,5 \frac{1}{2}, 9$, and 18 months-more in the earlier stages.

In a later communication by Boring and Pearl the whole question is taken up again with improved methods, etc. Previously 21 male birds had been studied, just hatched to 12 months old. More sections of this same material were made which were stained according 
to Mann's and Mallory's methods. In addition, a whole new series of preparations was made. A few interstitial cells, $i$. e., granule containing-cells were found in newly hatched chicks, but not in any of the 60 mature birds examined.

\section{LUTEAL-CELLS IN THE TESTES OF THE MALE SEBRIGHT.}

Finding that the testes of $\mathrm{F}_{2}$ hen-feathered birds were often flat and pear-shaped instead of rounded and cylindrical, as in ordinary cocks, and that they were often black in color, suggested, as already stated, that the testes of the Sebright might be hermaphrodite in some element. It seemed not impossible that egg-cells might be found. I made a considerable number of sections of the testes of these birds and examined them under the microscope; not finding any egg or egg-like bodies, the slides were laid aside, but the idea that in some other way the Sebright's testes might correspond to the ovary of the female next recurred to my mind. Consequently, when in the summer of 1918 I had some new material derived from a castrated Sebright male that had partly regenerated its testes and was again going back to henfeathering, and pieces from one of the old testes of a castrated bird, I asked Miss Boring, who was then in Woods Hole, to make some preparations and examine them to see if she could detect any such elements in them as she had found in the female. Miss Boring reported the occurrence of luteal cells in the testes from hen-feathered males, and the results have been published in a brief preliminary paper (1918). The abundance of these clear cells, supposedly gland-cells with endocrine influences, in the testes of hen-feathered birds is in sharp contrast to their absence in the normal adult cock birds. It seems to follow, therefore, that the hen-feathering in the Sebrights is due to the presence of these cells, whose function is the same as of the similar cells in the female, $i$. e., the suppression in both of cock-feathering. Castrating the Sebright produces its effect by the removal of these cells that are responsible for the suppression of cock-feathering.

The occurrence of luteal cells in young stages of other races of poultry raises the question as to whether in these races the first or juvenile plumage, that resembles that of the hen rather than that of the cock, may not also be due to an internal secretion from these cells, or whether this juvenile plumage is only the plumage of a characteristic stage in development. Castration of young chicks ought to settle this point. Such castration experiments have been made by Goodale. The absence of any reference to any effect on the juvenile plumage in these early castrated birds probably meant that they did not develop precociously cock-feathering, and he writes me that he examined them carefully and that their plumage is like that of the normal chicks. Geoffrey Smith has reported the occurrence of two kinds of males 
in a race of Leghorns, the males of one of which become cock-feathered before the other. May not this difference depend on the length of time endocrine cells remain or begin to develop? A histological study of the two types would be of the greatest interest.

\section{ENDOCRINE CELLS IN THE TESTES OF MAMMALS.}

In man and other mammals it has long been recognized that in addition to the germinal cells of the testis there are also present other cells, sometimes called interstitial cells, that, so far as known, have no immediate function in connection with the germ-cells, or at least that have other important funetions outside the relation to the reproductive organ. That some internal secretion from these eells has an important influence on the secondary sexual characters rather than anything done by or produced by the germinal cells has been very clearly shown by evidence derived from three separate sources, namely, from the operation known as vasectomy, from an exceptional condition known as cryptorchidism, and more indirectly from $\mathrm{X}$-ray treatment. Vaseetomy involves either cutting the vasa deferentia in such a way that the cut ends do not reunite. In consequence of the closure of the outlet of the testis the germinal cells slowly degenerate, and finally completely disappear. How such an effect is produced we do not know. That this result does take place is borne out by the unanimous testimony of all those who have successfully performed the operation. Ancel and Bouin showed (1903) that breaking the continuity of the vas deferens suppressed spermatogenesis in 8 to 12 months. Both the Sertoli cells (the nourishing cells of the germinal epithelium) and the interstitial cells persist. Such animals remain sexually active and their secondary sexual characters are not affected. Marshall states that in the hedgehog the remarkable periodic enlargement of the testis takes place even after vasectomy, although the germ-cells have disappeared.

In mammals the testes fail at times to pass through the inguinal canal, and, in consequence of their retention in the body-carity, the germ-cells fail to develop. On the other hand, the interstitial cells of the testis develop normally. Cryptorchid individuals show the normal secondary sexual characters of their species. How retention of the sperm should give rise to the same result as cutting the duct, viz, absorption of the germinal cells, is not known. A possible solution may be found in the pressure exerted on the testes, both when retained in the abdomen and when their outlets are stopped by tying or cutting the ducts.

Finally, it has been long known that continued or repeated exposure to X-rays or to radium causes the destruction of the germ-cells, but leaves the interstitial cells intact and presumably functional. Destruc- 
tion of the germ-cell by X-rays has no effect on the secondary sexual characters.

This threefold evidence demonstrates that in the male of the mammalia most, perhaps all, of the secondary sexual characters that are affected by castration are not affected by the destruction of the germcells. This conclusion supports very strongly the view that the interstitial cells are the cellular element in the testes that influence through internal secretion the development of the secondary sexual characters of the male.

Equally important are the results that relate to the accessory organs of reproduction, such as the glands that open into the vas deferens (prostate, Cowper's gland, etc.) and the copulatory organs also. In the castrated mammals these organs diminish in size. On the other hand, after destruction of the germ-cells in the testes (or even when they fail to develop as in cryptorchid individuals) these accessory parts are unaffected. In birds, as will be shown, the situation is entirely different.

\section{CYCLICAL CHANGES IN THE INTERSTITIAL CELLS IN HIBERNATING MAMMALS.}

The changes that take place in the interstitial cells in mammals that hibernate and in which there is a definite rutting season following hibernation have been examined by several workers. The mole has been studied by Regaud (1904), Lécaillon (1909), Tandler and Grosz (1911); the marmot by Hauseman (1895) and Gaugini (1903); the hedgehog by Marshall (1911); and the woodchuck by Rasmussan (1917). In the mole the interstitial cells are most abundant when the tubules in which the spermatogenesis is taking place are least developed, and vice versa. In the hedgehog the increase in both tissues takes place at the same time. In the woodchuck both tissues increase rapidly after hibernation (during March and April), after which the spermatogenesis continues actively for the two following months (May and June), while the interstitial cells retrograde rapidly during April and remain at a low level for the rest of the year. Retrogression in the germinal epithelium begins in July, after the rutting season is past. It appears from this evidence that the activity of the two tissues does not always run the same course. Since the secondary sexual characters of the male, which are not well developed in these animals, are not so far as known affected by the condition of the testes, the evidence does not have any very direct bearing on our present topic. How far the sexual behavior of these mammals is determined by the quantity or by the activity of the interstitial cells is not very clear from the evidence, although there is a very noticeable increase in the amount of this tissue just before and during the rutting season. In the mole also the 
interstitial cells begin to inerease just before the mating season, and the increase continues for several months after mating has taken place. It is difficult to judge how great or how little the change amounts to unless the whole organ is considered, for the relative volumes of the seminal tubes and the interstitial tissues does not give a measure of the total volume of these tissues, since the testes may decrease greatly in size when the seminal tubes retrograde, and the apparent increase of the interstitial cells at the time may not increase the total amount of that tissue present.

Probably more important than the ratio of interstitial tissue to tubules is the activity of the former. Rasmussan states that in the woodchuck the interstitial cells not only increase in number immediately after hibernation, but the increase in amount of this tissue is largely due to increase in the cytoplasm, in which there appears an accumulation of fatty globules in the more peripheral parts of the cells. In the central cytoplasm an abundance of fine lipoid granules develops.

Marshall has made some interesting experiments on the hedgehog at different seasons. Castration in March prior to the breedingseason has an influence on the accessory generative organs (vesiculie seminales, prostates, and Cowper's glands). They remain in the same undeveloped stage in which they were at the time of operation. If castration is carried out very early in the breeding-season, when the accessory reproductive organs are about half developed, their further enlargement is prevented. In so far as the accessory organs rank as secondary sexual organs, their complete development is thus shown to depend on the testes. Transection of the vasa deferentia before the beginning of the breeding-season affects somewhat the enlargement of the testes, but produces no effect on the accessory organs.

\section{HERMAPHRODITISM IN POULTRY AND THE SECONDARY SEXUAL CHARACTERS.}

Several hermaphrodite birds have been described (Brandt, 1Ss9; Shattock and Seligman, 1906; Pearl and Curtis, 1909; Smith and Thomas, 1913; Bond, 1914; ete.). The most recent and complete account of such birds is that by Boring and Pearl. They examined in all 8 hermaphrodites, or at least 8 birds that showed in their plumage, or other secondary sexual characters, peculiarities of both sexes. Five of the birds eame from Herr Houwink in Meppel, Holland, who had a stock in which there appeared, in 1911, two hermaphrodites out of 80 birds, and in 1912, three out of $S 0$ birds. These were the birds studied by Boring and Pearl. In addition, when Pearl saw Herr Houwink's birds in 1910, "there were then on hand a eonsiderable number of these supposed hermaphrodite birds." An anatomical study of the Holland birds showed that one of them was nearly a normal female; three, the 
authors say, were "evidently undeveloped females. They have infantile oviducts and embryonic ovaries." It should be added that there was a tumor more than twice the size of the ovary attached to or part of the ovary. If the ovary itself was affected by the tumor, or the tumor was a part of the ovary, the slightly unusual condition of the birds might be accounted for. Of the other 3 birds, 2 are also suspected to have ovarian tumors, while in the third bird streaks of a secretion which resembles the substance of the tumor of the other two were found. The change towards male plumage in these 5 birds is probably due either to the incomplete development of ovary or to the effect of the tumor on the ovary. Although luteal cells are described as present, it seems probable that their total number might be less than in a normal bird, and hence their insufficient secretion would fail to suppress the development of male plumage. From this point of view these birds are no more hermaphrodites than is a hen with her ovary taken out.

The remaining Holland birds were entirely different. On the left side there was an ovary in an inactive condition; on the right side there was a testis, producing spermatozoa. Sections of the testis show that it is normal, consisting of a mass of tubules with very little connective tissue between them. In both ovary and testis there are "a few nests of luteal cells near the surface. The ovary contains eggs, but is abnormal to some extent." The authors state:

"In external appearance it is more like a male than the others, which fact correlates well with the active condition of the testis and inactive diseased ovary, with only one corpus luteum scar. The interstitial cells can scarcely be held accountable for the male secondary sex characters, as the only ones in an active secreting condition are a few in the ovary."

It is not quite clear what is meant in this quotation by the statement that the interstitial cells can scarcely be held accountable for the male secondary characters unless to suggest that they cause the development of these characters in the male, as they are supposed to do in mammalsa view that the authors do not seem at other times to hold.

Another hermaphrodite (Atwood's black) had an infantile oviduct and an ovotestis. A second bird, too, had an ovotestis-mostly testis-as well as a rather large oviduct. Collections of luteal cells are described between the tubules of the testicular portion. If, as suggested by the Sebright cases, these cells tend to suppress the female plumage, their presence here in excess might at least be made to account for the female part of the plumage of this bird. Comparing the last two birds (that showed active sex-behavior as males) with the best of the Holland birds, Boring and Pearl point out that the active sex behavior of the two former can not be due to "interstitial cells that are absent in these but present to a slight extent in the former." They then add". . . though the differences can not be laid to the lutear cells, 
as they are present in all three." That the relative amounts of the latter or their activity might still be accountable for the difference would not seem entirely excluded from the evidenee so far as it is given.

A fourth hermaphrodite (Dexter's) laid $12 \mathrm{eggs}$ and had a large coiled oviduct. There was present "a large, lobulated reproductive organ on the left," which proved to be an ovotestis. Several ovarian tumors were present and there was testicular tissue.

It is fairly evident, then, that four of these birds deseribed by Boring and Pearl were females with abnormal ovaries. The incomplete development of the latter, or their abnormal condition due to tumors, may sufficiently explain the occurrence of male secondary sexual characters. That these tumors affect, to different degrees, such characters is expected from what is shown by imperfectly spayed females of normal breeds.

There are a few statements in the summary of this paper that eall for comment. The statement that the "development of comb, spurs, and wattles does not stand in direct quantitative relation to the sex of the gonad," appears to be only intended as a statement of fact based on the author's observation. But in what sense is there an expectation that they should stand in such relation beyond the obvious fact that in the cock the comb and wattles are larger than in the hen, and that spurs are generally present only on the eock. But if the expression "sex of the gonad" implies the germ-cells it is not at all certain that there is any expectation of a quantitative relation, and there is some probability at least that other cells than the sex-cells are involved in the development of combs, wattles, and possibly spurs. A castrated cock has a small comb resembling that of the female bird. On the other hand, removal of the ovary sometimes leads to an increase in the comb and wattles. Here we have, to say the least, a paradoxical situation, for the result looks superficially as though something in the ovary keeps down the hen's comb, while something in the testes keeps up the cock's comb, yet when the ovary is removed the hen develops a cock's comb; when the testes are removed the cock develops a hen's comb. The real meaning is, I think, that the genetic complex for femaleness (one Z or else ZW) stands in itself for a full-sized comb, while the genetic complex for maleness (two Z's) stands in itself for small comb.

Boring and Pearl state that "body-shape and earriage have a genetic relation to the sex of the gonad." This statement means, I think, that the amount of testicular matter present stands in some direct relation to the shape of the body and earriage of the male. Castration, both of the normal cock and the Sebright, seems to change the carriage somewhat and perhaps the shape. Both lose something of the peculiar attitude of the male, but I have not been able to my own 
satisfaction to analyze what this means. As has been pointed out, and as the pictures show, the castrated Sebright changes his attitude, but whether this is a change due to his new contour, or to a new balance resulting from a large tail, or to a let-down resulting principally from effects on the nervous system, is difficult to determine. The same statements apply in part to the castrated cock of ordinary breeds, but not to the same degree, since the change after castration, in feathering and in carriage at least, is slight.

The conclusions that the "amount of lutear cells or pigment (?) is in precise correlation with the degree of external somatic femaleness exhibited by the individual" is of especial interest in connection with the Sebright evidence. It is difficult, however, to gather from the body of the paper what the absolute amount of luteal cells is that is present, for even in some of the more male-like birds with an ovotestis the description leads one to suppose that there may be as much luteal material present as in some of the more female birds with infantile ovaries or cystic tumors.

Pearl and Curtis (1909) described "a case of incomplete hermaphroditism" in a Barred Plymouth Rock fowl. Externally the bird looked like a hen, but "the head and neck resembled these parts in the cockerel," especially the comb and wattles. The bird was never seen to tread a hen, nor did it ever crow normally. An ovary and oviduct were found on the left side, the former no larger than that of a laying hen after removal of the large yolks. No eggs were visible on its surface. On the right side a testis $(9 \mathrm{~mm}$. by $6 \mathrm{~mm}$.) and vas deferens were present. No eggs were found in the ovary, and it gave every indication of being in a degenerating condition, with no eggs or egg follicles in it. The testis had no "normal seminiferous tubules," but indications of cellular rods were present. The organ is in all probability a degenerating testis.

A Leghorn 2 years old has been described by Shattuck and Seligmann (1906) that had the full-developed comb and wattles of the cock, but the former drooped slightly to one side as in the hen. Welldeveloped spurs were present. The plumage was mainly female, with neck-hackles moderately developed, and with "saddle-hackles" practically absent. The tail, though not typically female, lacks sickle feathers. The bird excited no notice from other birds of either sex. A large left oviduct and the distal end of a right oviduct were present. Two vasa deferentia were also present. In the left side a flattened sexgland $(3 \mathrm{~cm}$. high) was found, made up of testicular tubules. Two small ova were found in its posterior end. The right gonad was also tubular (testis).

The occurrence of real testicular tissue in one of the Holland birds and in three others described by Boring and Pearl, as well as in one 
described by Pearl and Curtis, and in another by Shattuck and Seligmann calls for special comment, since the presence of both testieular and ovarian tissue in the same bird is the essence of hermaphroditism. In general there are two ways of looking at such a result. Either the sex-determining factors have been changed so that in one part of the body, where the reproductive organs are laid down, one condition can prevail, in other parts other conditions; or a mixup of the sex chromosomes has taken place. Until we get some more evidence concerning such cases it is useless to speculate, although the former view might seem the most probable of the two if the Holland birds of Herr Houwink's flock were in a high degree true hermaphrodites.

But in fact three of the four deseribed by Boring and Pearl were due to tumors of the ovary, which, if they suppress the normal development of this organ, would be expected to call forth the appearance of the secondary sexual characters of the cock. If the likelihood of developing a tumor were inherited, the frequent occurrence of henfeathered birds in this flock would be explained. However, one true hermaphrodite in 4 birds is surprisingly high for a chance result, since hermaphrodite birds are very rare.

The second interpretation suggested above is one that has been advanced and established by genetic evidence in Drosophila, viz, dislocation of the sex chromosomes. In the case of birds the male is supposed to be duplex for the sex factors (ZZ), the female simplex (ZW), and consequently the chromosome-dislocation hypothesis must be worked out contrawise in birds and insects. We should have to suppose that such birds start as males (ZZ), and that at some division of the cells of the embroyo one of the Z's became lost (left at the cellwall for example). All the cells that got $\mathrm{ZZ}$ would be male; all that got $\mathrm{Z}$ would be female. If the reproductive region included cells of these two kinds, an ovotestis would result. The rest of the body should be the same, or nearly so, since the soma of male and female birds is alike whether ZZ or Z, except in so far as it is affected by the secretions from the ovaries (in most races of poultry), or from the testes if the race be Sebright, Campines, or Hamburgs. Birds with ovotestis might, nevertheless, be expected, on this view, to show at times an intermediate condition of the secondary sexual characters, according to how much internal secretion is produced in the ovotestis. In other words, the chromosome loss might involve much more extensive regions than the reproduction organs, but show its effects first in that organ and then indirectly other parts of the body be affected by the luteal cells of the testis. There is one rather good piece of evidenee that seems opposed to this interpretation. In the hermophrodites the oviduct is present in all cases. Its conspicuous presence in the four hermaphrodites would seem, therefore, to indieate that the birds 
started as females (ZW), which is inconsistent with the dislocation hypothesis. The alternate would be that in all these cases the $\mathrm{Z}$ part always included the region of the oviduct, which seems improbable.

There is another possibility, viz, that in birds a sex-factor is carried by the $\mathrm{W}$ chromosome, and $\mathrm{ZW}$ is a female not because of one $\mathrm{Z}$, but due to the presence of $W$. If so, then one $Z$ or two Z's might give the same result, viz, female. If a bird started as female, (ZW) and chromosomal dislocation occurred, then the $Z$ parts would be female and the male part W. Until we get evidence on this point it is not worth elaborating. Without genetic evidence from hybrids, the interpretation of hermaphrodites in birds can have at present only a speculative interest. We may hope some day to get the same kind of evidence as in the case of Drosophila. Hermophrodite hybrid pheasants that have been often described might seem to furnish a hopeful field, for they appear to be quite common and to show characteristics of both races. As yet, however, no one has, I think, succeeded in finding a simple interpretation of the results. It is also not unlikely that many of the pheasant cases are not true hermaphrodites, but due to failure of normal development of the reproductive gland, which gives an intermediate or mixed type of secondary sexual characters. 


\section{PART II.}

\section{DARWIN'S THEORY OF SEXUAL SELECTION.}

Darwin seems to have felt the necessity of giving some other explanation for the secondary sexual differences between the male and female than that such differences were only a by-product or concomitant of sex itself. His reason for searching further was probably a part of the general point of view he had reached in regard to the utility of special structures of animals, namely, that their presence finds its explanation on the basis of utility. Believing as he did that most of the adaptations of plants and animals have been built up by the accumulation of small steps, it must have appeared to Darwin inconceivable that the highly developed ornamentation exhibited in the secondary sexual characters could have been simply the by-product of sex itself, especially when the ornamentation may have been entirely absent in males of closely related species. To-day we are not, I think, so oppressed with the difficulties of the situation, for we have become familiar with the fact that very slight genetic differences may cause very great differences in the end-product. In a -word, the problem seems less formidable to us than it did to Darwin.

Darwin appealed to three processes to account for the facts: (1) to natural selection between the members of the same sex; (2) to choice on the part of the "other" sex; (3) to the "inheritance of use." Since each of these appeals to a different procedure, let us take them up separately.

Competition of the males with each other for the female would, Darwin said, lead to the survival of those males best endowed with organs of offense and defense. The spurs of the cock are weapons dangerous for other birds; the horns of the bull and those of deer are used for offense and defense; the mane of the lion is a protection against the teeth of other lions. It is true that these same weapons and shields serve for attack and defense outside the species; but since the female lacks them or has them less developed, they would not scem necessary for survival of the individual against aggression from without. They have developed, then, through competition within the species.

Several objections of greater or less weight have been urged against Darwin's interpretation. It has been pointed out that the combats within the species are seldom fatal and that the defeated rival finds another mate. If, as a rule, there are as many females as males within the species and monogamy is the rule, all males will find partners sooner or later, all may have offspring, and the offspring have equally good chances of survival. Under these circumstances it is not to be expected that the combat would be likely to lead to the production of males with longer spurs or larger horns. 
Darwin realized this difficulty and tried to meet it by another assumption, viz, that the better endowed males would also be more likely to have more offspring. How could this be made probable? Darwin suggested that the strongest males would be in position to mate with the first females to reach maturity, and if these were more likely to have offspring, either because of maternal endowments that made them also more prolific or because the earlier broods would have a better chance of getting food, etc., then the successful competitor would sooner or later impress his advantages on the race.

At other times Darwin suggested that the exceptional vigor that led to the greater development of the character in question would itself be of value and through transmission to the offspring lead to advance in the development of the other character in question. But here the argument shifts to another field of inquiry and survival is ascribed to greater vigor, while the secondary sexual character is carried along in its wake as a sort of correlated effect.

It will be conceded, I think, that such pleading does not help the argument, but exposes rather its inherent weaknesses. There is, however, a line of defense that is permissible. If monogamy is not the rule, if the male captures or attracts several females and keeps a harem, as do the fur seals and walruses, or rules a herd as does the bull, or has a flock as does the cock, or mates more frequently with random females than do some other males, then the advantage of his more developed weapon might lead to more offspring. If it could be shown that such intraspecific weapons prevail more frequently within polygamous species, a fair argument for natural selection might be made. I do not know whether such a census has been taken as yet, but it is true, I think, that in most polygamous groups we find weapons of offense very highly developed. The fur seal has a harem and the male is greater in size, in strength, and in the development of his tusks than is the female. Similarly for the walrus. The bull drives away rival bulls from the herd until through age or injury, or through the development of a better fighter, he is replaced. If the better endowment is due to a genetic factor, we should expect natural selection to keep the race at the highest possible level that variation supplies material for. If, then, we confine the application of natural selection to cases of this sort, the explanation is as valid as is the theory in other fields. Such a conclusion becomes weakened when an attempt is made to apply it to other groups of animals in which it appears improbable that the secondary sexual characters of the male have any obvious value as organs of offense. There are families of beetles, for example, in which the development of the horns of the male are as striking as are those of the ram or the stag. The males of these beetles are not known to fight with each other, nor are they polygamous. It may seem that we must look here for some other explanation, which, if found, might suffice to 
cover also the case of birds and mammals. In answer to this criticism it may be argued that it is also possible that the other explanation when found need not necessarily apply to the higher animals, where the laws of combat may still give the true explanation. On the whole, I think that, for our present purpose, it will suffice to state it is consistent with the theory of natural selection to accept proirsionally this part of Darwin's theory for those species in the higher groups in which polygamy holds, conceding, however, that even here it may have to be altered when fuller knowledge is gained.

We are more concerned with that special feature of Darwin's theory of sexual selection that is applied to those cases where the characters are supposed to owe their special development to selection by the individuals of the opposite sex. It is assumed that the female chooses the better endowed males, because of the strong appeal he makes to her sense-organs. Here we must employ perforce or for brevity's sake the terms used in human psychology, and run the risk at every turn of imputing to other animals the emotions and acquired associations which man himself utilizes. Even granting that other animals possess somewhat similar emotions to ours, there still remains always the danger, in the absence of real evidence, of imputing to them the particular emotion that we call "feeling for beauty"; and the greater danger of imputing an esthetic sense so highly developed that the choice falls in the long run on the suitor better ornamented than his rivals.

\section{OTHER THEORIES TO ACCOUNT FOR SECONDARY SEXUAL CHARACTERS.}

Wallace has always been an opponent of Darwin's theory of sexual selection in so far as it is based on female choice. As already stated, he believes that the difference between the plumage of the male and female in birds is due to natural selection keeping down the ornamentation and high coloration in the female, because these would be expected to expose the female while sitting on the nest to the attacks of enemies, more especially of hawks. In support of this view he points to a long series of species which build exposed nests and in them the female is plainly and inconspicuously colored, while he also points out that in such birds as parrots, toucans, woodpeckers, hangnests, and starlings, which nest in holes or have covered nests, the female is often as highly colored as the male. It can not be denied that he makes out rather a strong case in support of this view, despite the fact that there are other birds, like the Baltimore oriole, that have covered nests and in which the sexes are very markedly different.

Wallace tries to meet eases like the last one by assuming that the covering keeps off the rain; but, if so, why are the sexes still so different? In the case of other highly colored birds, such as jays, magpies, hawks, and crows, Wallace believes that these birds are all aggressive, hence 
can protect their nests if attacked. As a further support of his view, Wallace points out that in the few cases where the female is more highly colored than the male (as the dotterel, species of phalarope, an Australian creeper) the male incubates the eggs.

Wallace's suggestion still leaves unexplained the ornamentation of the male, which he tries to account for as the direct result of the greater vitality of the male. He tries to show that excessive ornaments and high coloration develop especially in those parts of the body to which there is an unusual supply of blood or where nerves and blood-vessels emerge to go to the skin or to the muscles.

"If we have found a vera causa for the origin of ornamental appendages of birds and other animals in a surplus of vital energy, leading to abnormal growths in those parts of the integument where muscular and nervous action are greatest, the continuous development of these appendages will result from the ordinary action of natural selection in preserving the most healthy and vigorous individuals, and the still further selective agency of sexual struggle in giving to the very strongest and most energetic the parentage of the next generation. And, as all the evidence goes to show that, so far as female birds exercise any choice, it is for ' the most vigorous, defiant, and mettlesome male,' this form of sexual selection will act in the same direction, and help to carry on the process of plume development to its culmination. That culmination will be reached when the excessive length or abundance of the plumes begins to be injurious to the bearer of them; and it may be this check to the further lengthening of the peacock's train that has led to the broadening of the feathers at the ends, and the consequent production of the magnificent eyespots which now form its crowning ornament.

"The display of these plumes will result from the same causes which led to their production. Just in proportion as the feathers themselves increased in length and abundance, the skin-muscles which serve to elevate them would increase also; and the nervous development as well as the supply of blood to these parts being at a maximum, the erection of the plumes would become a habit at all periods of nervous or sexual excitement. The display of the plumes, like the existence of the plumes themselves, would be the chief external indication of the maturity and vigor of the male, and would, therefore, be necessarily attractive to the female. We have, thus, no reason for imputing to her any of those esthetic emotions which are excited in us, by the beauty of form, color, and pattern of these plumes; or the still more improbable esthetic tastes, which would cause her to choose her mate on account of minute differences in their forms, colors, or patterns."

Wallace says, referring to the immense tuft of golden plumage in the best known birds of paradise (Paradisea apoda and P. minor) that springs from a very small area on the side of the breast, that Mr. Frank E. Beddard, who has kindly examined a specimen, says that "this area lies upon the pectoral muscles, and near to the point where the fibers of the muscle converge towards their attachment to the humerus. The plumes arise, therefore, close to the most powerful muscle of the body, and near to where the activities of that muscle would be at a maximum. Furthermore, the area of attachment of the plumes is just 
above the point where the arteries and nerves for the supply of the pectoral muscles, and neighboring regions, leave the interior of the body. The area of attachment of the plume is, also, as you say in your letter, just above the junction of the coracoid and sternum." "Ornamental plumes of considerable size rise from the same part in many other species of paradise birds, sometimes extending laterally in front, so as to form breast shields. They also occur in many hummingbirds, and in some sun birds and honey-suckers; and in all these cases there is a wonderful amount of activity and rapid movement, indicating a surplus of vitality, which is able to manifest itself in the development of these accessory plumes."

There are two serious defects in such an attempt to explain the facts. In the first place, it has been shown in several cases that have been studied that it is not the lessened "vitality" of the female but the suppression caused by the ovary that keeps down the development of the full plumage in that sex. In the second place, the anatomical influences appealed to are imaginary rather than real, for it is by no means apparent that the local exits of blood-vessels and nerves to muscles are at all correlated with the location of the ornamental parts, in the skin. Even when larger blood-vessels run to the region of excessive development of feather ornaments it may well be that they go there because the ornaments in question use them for their nourishment; in other words, Wallace puts the cart before the horse. The top of the head, where crests so often develop, the throat coloration and throat shields of hummingbirds and birds of paradise, the two long tail feathers of several species of hummingbirds, etc., do not arise, so far as known, from regions which are conspicuous for a rich supply of blood and nerves. Wallace's appeal to underlying organs such as muscles that supposedly influence the special development of the feathers in the skin above does not strike one as a fortunate appeal to physiological principles.

Hudson, in his interesting book, "The Naturalist in La Plata," has also criticized Darwin's theory of sexual selection. He has brought together a considerable number of interesting observations that go to show that the displays - dancing, singing, and combats - of males and females have no relation to mating. Many of them involve birds already mated, sometimes several males participating, sometimes males and females together. Some of the tourneys he describes are more elaborate than the mating instincts themselves, yet are not concerned with mating. He attempts to explain them as overflow phenomena, $i . e$., as expressions of the high vitality of the males, especially at this time. If he is right, then elaborate exhibitions of these kinds have evolved that have no special connection with mating. Are we

1 For activity and pugnacity in hummingbirds, sce Tropical Niature, pp. 130, 213. 
called upon for a different explanation for other differences that distinguish the sexes? One example will suffice to bring out a curious emotional (?) display that, elaborate as it is, has no apparent connection with mating (p. 269):

"The lapwing display, called by the natives its 'dance' or 'serious dance'by which they mean square dance-requires three birds for its performance, and is, so far as I know, unique in this respect. The birds are so fond of it that they indulge in it all the year round, and at frequent intervals during the day, also on moonlight nights. If a person watches any two birds for some time-for they live in pairs - he will see another lapwing, one of a neighboring couple, rise up and fly to them, leaving his own mate to guard their chosen ground; and instead of resenting this visit as an unwarranted intrusion on their domain, as they would certainly resent the approach of almost any other bird, they welcome it with notes and signs of pleasure. Advancing to the visitor, they place themselves behind it; then all three, keeping step, begin a rapid march, uttering resonant drumming notes in time with their movements; the notes of the pair behind being emitted in a stream, like a drumroll, while the leader utters loud single notes at regular intervals. The march ceases; the leader elevates his wings and stands erect and motionless, still uttering loud notes; while the other two, with puffed-out plumage and standing exactly abreast, stoop forward and downward until the tips of their beaks touch the ground, and sinking their rythmical voices to a murmur remain for some time in this posture. The performance is then over and the visitor goes back to his own ground and mate, to receive a visitor himself later on."1

Cunningham, who has brought together many interesting cases of secondary sexual differences in his book on "Sexual Dimorphism in the Animal Kingdom," attempts to show that the development of the secondary sexual characters of the males are due directly to the use of certain parts of the body during courtship-the use of the parts leading to the enlargement and excessive growth of the parts. The effects are believed by him to be inherited, and he tries, furthermore, to show the way in which such acquired characters could be inherited. He makes use of the modern idea of hormones-substances that are elaborated in many organs of the body, whose effects are often most conspicuously produced in other parts of the body. He imagines these hormones to be collected in the germ-cells and transmitted to the next generation, where their presence contributes to the further development of the special region (when it develops) that corresponds to the region in its parent in which the hormone was made. His speculation meets in the first place with the general objections inherent in Lamarck's theory-objections so well recognized to-day that I need not go over them here. His special appeal to the hormone theory makes use of that theory in a way to which it was never intended to be put, by assuming that an internal secretion formed in one organ can be stored up in another organ, eggs and sperm-an assumption not only unsupported by any evidence, but, as I have stated, one quite foreign to the hor-

${ }^{1}$ The Naturalist in La Plata, W. H. Hudson, London, 1892, pp. 269-270. 
mone theory. In fact, Cunningham's suggestion is nothing more than Darwin's old idea of pangens, which, being imaginary, could be endowed with all desirable properties. But one can not invoke a chemical substance, even a hormone, and then at the critical moment endow it with special virtues.

A rather unique explanation of the origin of secondary sexual characters is made by Stolzmann. His argument runs as follows: (1) There is a great excess of males in birds; (2) the males left over after mating are useless to the species, since they can not propagate and they consume food needed by the reproducing part of the population; (3) the conspicuous coloration of the male has been evolved in order that he could be seen more readily by birds of prey and the objectionable excess of males removed; the comb of the cock has developed in order that he may be the more easily killed by other cocks.

Stolzmann's account of the origin of the plumes of the birds of paradise should be immortalized in the literature of the subject:

"Nous comprendrons aussi facilement la présence de longues plumes chez les males de nombreuses espèces, comme p. e. chez les oiseaux de paradis, chez les veuves (Vidua) et chez l'engoulevent africain (Cosmetornis). Telles plumes ont probablement pour but de relantir le vol des males. J'ai constate chez la Loddigesia mirabilis (oiseaumouche péruvien), que le vieux male posséde l'aile quelques millimetres plus courte que le jeune male ou la femelle. Cet avortement des remiges provient assurément a cause de développement extraordinaire de retrices externes chez le vieux male de cet oiseaumouche. Si donc d'une part les retrices allongees rendent le vol plus difficile et d'hautre les ailes plus petites diminuent sa vélocité, le vol du male doit ètre plus lent que celui de la femelle, le poids du corps restant la même. Le développement extraordinaire soit des remiges soit des rectrices, en relantissant le vol des males, rend leur rôle plus difficile, en facilitant en mème temps celui des femelles. Nous pouvons prendre comme exemple le Cosmetornis, qui, comme tous les engoulevents, se nourrit d'insectes, qu'il attrape au vol. Chez cet oiseau quelques plumes des ailes se developpent extraordinairement pendant l'époque de reproduction, en retardant visiblement son vol. Il est done facile a remarquer, qu'alors le male, ayant les mouvements plus lourds, n'est pas en ètat de se proeurer la même quantité d'insectes qu'auparavant; ainsi donc la femelle a plus de chances de trouver une nourriture plus abondante." \&

Equally worthy of perpetuation is Stolzmann's explanation of dancing and singing birds:

"Toutes les réunions des males, leurs danses bizarres, leur chant, enfin, ne servent pas probablement a séduire les femelles, mais pour distraire les males, ce qui rend plus faciles les besognes maternelles des femelles et au surplus les protege contre l'assiduite nuisible des célibataires. Darwin lui-mème constate le fait, qu'ordinairement pendant les réunions des males, quand ces derniers sont trop occupes par le combat ou la danse, la femelle s'echappe avec un d'eux pour copuler. Ainsi done dans ce cas c'est bien la selection naturelle et non la selection sexuelle, qui agit pour la conservation d'équilibre sexuel." '

\footnotetext{
${ }^{1}$ Proceedings of the Zoological Society of London, 1885, p. 431, Quelques remarques sur Io dimorphisme sexuel. Jean Stolzmann.
} 


\section{DISPLAY OF THE MALE.}

The antics of male birds at the mating season, their courtship so-called, has played an important rôle in Darwin's theory of sexual selection. The behavior of many birds at this time is of such a kind as to suggest that the male is exhibiting his plumage before the female for the "purpose" of influencing her choice. The whole paraphernalia of human psychology is imported into the situation and both the consciousness of the male, his intentions so to speak, and the supposed esthetic response or choice of the female is invoked. Even though it be granted that the words that we must make use of, borrowed from human behavior, are such as to imply much more in the direction of consciousness and purpose than is desirable, and that most of the behavior of animals should be stated in a more roundabout and objective way, yet the theory will only work out on the assumption that the female chooses in some sense the more brilliant or ornamental (or effective) male, whether she is "conscious" or unconscious of intention. I doubt if anyone to-day would care to defend seriously the theory on the grounds of consciousness or esthetic value of the exhibition, despite the fact that Darwin's language often takes this turn and the less-guarded statements of some of his disciples, such as Romanes, show little hesitation in anthropo-morphologizing the entire situation. It is, however, not necessary for the working out of the theory that this complication be introduced into it, for if the female is more likely to mate with a more brilliantly colored than a less brilliantly colored male, the theory may be made to apply regardless of whether she is "conscious" or not of the difference to which she responds.

But there are weighty arguments against such an interpretation of the behavior of the male and female during courtship. In the first place, there is almost no direct evidence to show that the female mates with the more ornamental male. As this is the all-essential requirement of the theory, the almost complete absence of facts in its support leaves the theory resting on a theoretical assumption. It can scarcely pass unnoticed that while there exists a large mass of data describing the secondary sexual characters, there is practically nothing in this accumulation to show that the female makes her selection on differences in coloration or ornamentation. And on the other hand, there is some evidence showing that the female is ready to succumb to the aggressiveness of the male rather than that she "chooses" him.

The behavior of the male under sexual excitement is often described to be of a kind to exhibit before the female his peculiar adornments. That the "purpose" of his exhibition is to show himself off before the female may be conceded, with reservations as to what is meant here by "purpose." That the male is conscious of the probable results of his conduct is scarcely probable the first time he courted; but that he may 
have found out the most probable result after the first attempt through "associative memory" is in accord with what the study of "animal behavior" has shown to be possible. In this sense purpose would mean a line of conduct that experience had shown to lead to a certain end. Anticipation or far-sightedness would henceforth characterize such a reaction. Here, however, we venture on very dubious grounds. But the display of the male may be purposeful in a much simpler sense. His activity may be an inborn reflex to visual or other sensory stimuli that is a part of his attack on the female, or possibly a series of reflexes that we may register under the old unanalyzed terms of "desire and fear." The action calls forth a responsive reflex in the female, for the sexual act is not entirely active on one side, passive on the other, but consists of a series of interreactions on the part of each sex, which, if they pursue a given course, leads to the final mating. The mutual responses appear to follow an automatic course in many cases if the individuals are sexually ready to mate and the environment is propitious. Types of behavior of this kind must be familiar to anyone who has observed domesticated and semi-domesticated animals. The purpose of the display may mean no more than a reaction that leads to a result propitious to the perpetuation of the species if the situation is ripe for such an outcome.

This conclusion still leaves open the question as to whether the display is more likely to be successful, if certain special characters possessed by the species are exhibited. In the absence of any sufficient evidence to show that this is so, and in the light of the very great danger of projecting "our human standards" into the world of other animals, and in view of the fact that related species without such marks are as successful in maintaining themselves, I can not but think that at present we have a good deal to lose in the way of seientific procedure and nothing to gain of scientific value in accepting Darwin's interpretation of sexual selection based on the display of the male as furnishing an opportunity to the female to make the "best" selection amongst her suitors on the basis of his adornment.

An excellent opportunity to study the problem as to "choosing" by the female is furnished by the mutant races of Drosophila, some of which, differing in a single mutant gene, have wings as different in coloration as black, yellow, or gray, and eyes as differently colored as white, vermilion, or red. Sturtevant put a yellow female with a gray (wild-type) male and a yellow male. The male that first mated was noted and the trio discarded. The female "chose" the gray males 25 times and the yellow only 8 times. In the control combination, where a gray female "chose" between the same two kinds of males, she took the gray male 60 times and the yellow male 12 times. In both cases it "appears" that the female "prefers" the gray male, but this deduction may give an entirely wrong impression as to what is taking place, for 
the result would be the same in kind if the gray male were more active and mated quicker. This was tested by putting a gray and a yellow female with a gray male and then for control a gray and a yellow female with a yellow male. The result was as follows:

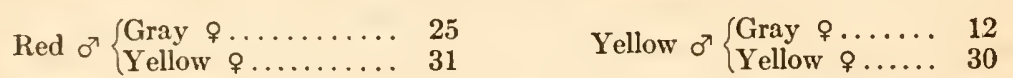

Here the gray male mated slightly oftener with the yellow female than with the other, whereas the yellow male mated much oftener with the yellow female than with the gray one. Both results are explicable on the view that the yellow female, being less active, is more easily captured by the yellow male than is the gray female. This view fits in also with the former experiment, where the yellow male is much less successful than the more active gray male. Such a conclusion gives a more consistent explanation of all the facts than does the theory of female choice, for on the latter we must suppose that the yellow females prefer the gray males and the yellow male prefers the yellow females, etc.

The following results were obtained by Sturtevant when red and white eyed flies were competing:

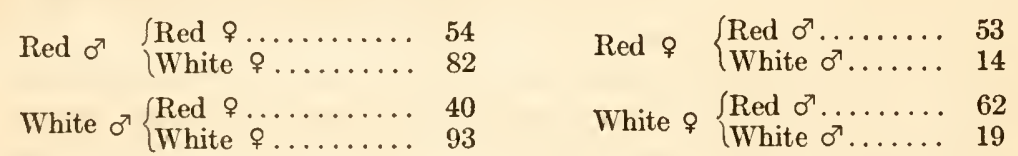

The outcome can be interpreted in the same way as the yellow-gray competition. The red male wins by virtue of his greater activity, while the white female is chosen more often, especially by the white male, because of her passivity (or weaker resistance). It may be claimed that these results do not show that the female does not choose, for such choice, if made, would be swamped by another condition of the experiment, viz, the greater aggressiveness of one kind of male and greater passivity of the other kind of female. This, of course, is true, but the experiment still shows that in these flies other influences are so much greater than "choice" by the female, if it exists, that the postulated effect of the latter practically disappears from the situation.

Mayer's experiments with the large moth Callosamia promethea furnish important information as to the factors involved in mating. The results are all the more significant from our present point of view because the colors of male and female are in this species markedly different. The wings of the male are black, those of the female reddish brown; the antennæ of the male are large and bushy, those of the female small and slender. Mayer found that the males are attracted by the female from some distance when the latter are put into a glass jar covered by only coarse mosquito-netting, but if the same jars are turned upside down the males are unable to find the female. Females 
concealed in loose cotton attracted males. Females were put into a box with an open chimney at one end, the other open end being covered by mosquito-netting. A current of air blew into the open end and out of the chimney. The males flew to the end of the chimney from which the air came and fluttered about in the neighborhood. Males are attracted to places where a female has been kept even several hours after her removal. The male finds the female through the sense-organs in his antennæ, for a male whose abdomen has been cut off and the sides of whose thorax are covered with shellac will still fly to the female, but if his antennæ be coated with any substance he no longer seeks the female. If the eyes of the males are blackened they will mate with females "in the normal manner."

Mayer cut off the wings of females and glued male wings in their places, so that the female looked like a male. Males readily mated with these females. The wings of males were cut off and female wings glued in their place. Mating occurred "with normal frequency, and I was unable to detect that the female displayed any unusual aversion" to such males. Males with female wings pass unnoticed by other males.

In a later paper (1901) Mayer and Soule describe how, when the wings of the male were painted scarlet or green, the males were accepted as readily as normals in competition with them. Experiments were also made by them with the gipsy moth. Wingless males met with more "resistance" from the female than do normal males, but when the eyes were covered the wingless males succeeded as often as the normal males, but the number of observations on which this statement is were far too few to be of any value, and there are several other observations that make any such conclusion from the evidence highly uncertain.

That it is the odor of the females that attracts the male can not be doubted. It might still be claimed that the female chooses amongst her suitors the darkest males, but the evidence gives no grounds for inferring such a choice, and since she will even accept males with female wings when they attempt to mate with her, it does not appar probable that the color of the male is a factor in the result, or at least if it is, then it must be entirely subordinate to the sense of smell in finding the female and of touch after he arrives. These is little or nothing in the behavior of these moths, or in that of the silkworm moth, according to Kellogg, to suggest that vision plays any significant rôle in courtship.

Concerning the genetic situation in insects, there are only a few cases that have been studied. The most instruetive are those in which more than a single kind of male exists (two or three), one of which may be like the female, the other quite different. The best worked out cases are Papilio memnon and $P$. polytes. De Meijere and Punnett have 
shown from the breeding data that it is possible to frame an explanation of such a sort that the aberrant female differs from the female resembling the male in only a single genetic factor-one not sex-linked (i. e., not carried by an $\mathrm{X}$ chromosome), but autosomal. The gene would be of such a sort that it affects the female only-producing no visible effect on the male. Such a conclusion, if established, helps, theoretically at least, toward simplifying the situation in other species, for it shows that genetic factors occur whose influence is on one sex alone; hence the difference between the male and one type of female does in such cases result from a single gene present in both but causing them to be differently colored. There would be no need, then, to assume that the difference had been slowly built up by selection, but rather that the difference arose at some time by a single mutant step. The incorporation of the step in the species would then follow if the effect of the gene were useful in mating or if it had some other primary significance for the welfare of the species, the different effect produced on the male and female being only an unimportant by-product of its action. On the other hand, it should be emphasized that because a single factor difference between the two kinds of females will explain the genetic results, it does not necessarily follow that the difference did arise as a single mutation. The foregoing argument does no more than imply that the difference in question may have arisen in this way, and if so, that the situation, as it exists, would be the more easily comprehended.

In insects and spiders, where dimorphism is as marked as in birds, the mating habits have been studied by a number of naturalists. Here alou there are numervus accounts of the display of the male during courtship. The account given by Dr. and Mrs. Peckham are particularly detailed and call for careful consideration on account of their well-recognized accuracy in observational work. Moreover, as a result of their observations, along with those of Montgomery, Petrunkewitsch, and others, we have really fuller information concerning the courtship of spiders than of birds and of mammals.

In the great majority of species where the sexes are different the male is more brightly colored or more ornamental. For example, in a group such as the Attidæ of France, where both sexes are known, the Peckhams state that in 26 cases the male is more conspicuous than the female; in 55 cases the sexes are alike, or if they differ the male is more conspicuous. It appears that in other genera there are cases where the female is more conspicuous than the male. The Peckhams state that possibly as many as 250 species are in this condition. Those females with brighter colors than the males are usually well armed by strong spines. When very young they are like the males and begin to assume the adult form and color when they are a quarter to a third grown. Whether the change depends on changes in the ovary is not known. 


\section{The mating behavior of Saitis pulex, a species in which the males} and females are much alike, is described by the Peckhams as follows:

"On May 24th we found a mature female and placed her in one of the larger boxes, and the next day we put a male in with her. He saw her as she stood perfectly still, twelve inches away; the glance seemed to excite him and he at once moved toward her; when some four inches from her he stood still and then began the most remarkable performances that an amorous male could offer to an admiring female. She eyed him eagerly, changing her position from time to time so that he might be always in view. He, raising his whole body on one side by straightening out the legs, and lowering it on the other by folding the first two pairs of legs up and under, leaned so far over as to be in danger of losing his balance, which he only maintained by sidling rapidly toward the lowered side. The palpus, too, on this side was turned back to correspond to the direction of the legs nearest it. (Fig. 13.) He moved in a semi-circle for about two inches and then instantly reversed the position of the legs and circled in the opposite direction, gradually approaching nearer and nearer to the female. Now she dashes toward him, while he, raising his first pair of legs, extends them upward and forward as if to hold her off, but withal slowly retreats. Again and again he circles from side to side, she gazing toward him in a softer mood, evidently admiring the grace of his antics. This is repeated until we have counted 111 circles made by the ardent little male. Now he approaches nearer and nearer and when almost within reach whirls madly around and around her, she joining and whirling with him in a giddy maze. Again he falls back and resumes his semi-circular motions, with his body tilted over; she, all excitement, lowers her head and raises her body so that it is almost vertical; both draw nearer; she moves slowly under him, he crawling over her head, and the mating is accomplished.

"After they have paired once, the preliminary courtship is not so long. When this same pair mated a second time, there was no whirling movement, nor did the female lift her body, as at first." (pp. 37-38). ${ }^{1}$

The courtship of another species, Dendryphantes capitatus, in which the sexes are entirely different, is described as follows:

"The males of capitatus are very quarrelsome, sparring whenever they meet, chasing each other about, and sometimes clinching. It is a very abundant spider with us, so that we often put eight or ten males into a box to see them fight. It seemed cruel sport at first, but it was soon apparent that they were very prudent little fellows, and were fully conscious that 'he who fights and runs away will live to fight another day.' In fact, after two weeks of hard fighting we were unable to discover one wounded warrior. When the males are approaching each other, they hold the first legs up in a vertical direction. Sometimes they drop the body on to one side as they jump about each other. These movement are very quick, and they are always ready for a passage at arms. When courting the females they have another movement. They approach her rapidly until within two to five inches, when they stop and extend the first legs direetly forward, close to the ground, the legs being slightly curved with the tips turned up. (Fig. 18). Whether it be intentional or not, this position serves admirably to expose the whole of the bronze and white face to the attentive female, who watches him closely from a little distance. (Fig. 19.) The males also give their palpi a circular movement, mueb as a person does when washing his hands. As he grows more excited, he lies down

1 George W. and Elizabeth G. Peckham. Observations on Sexual Selection in Spiders of the Family Attidæ. Nat. Hist. Soc. of Wisconsin, Vol. I, 1859, pp. 46, 47. 
on one side with his legs still extended. These antics are repeated for a very long time, of ten for hours, when at last the female, either won by his beauty or worn out by his persistence, accepts his addresses." (Pp. 45, 46.)

In another species, Dendryphantes elegans, both sexes are brilliantly colored.

"The male is covered with iridescent scales, his general color being green; in the female the coloring is dark, but iridescent, and in certain lights has lovely rosy tints. In the sunlight both shine with the metallic splendor of hummingbirds. The male alone has a superciliary fringe of hairs on either side of his head, his first legs being also longer and more adorned than those of his mate. The female is much larger, and her loveliness is accompanied by an extreme irritability of temper which the male seems to regard as a constant menace to his safety, but his eagerness being great, and his manners devoted and tender, he gradually overcomes her opposition. Her change of mood is only brought about after much patient courting on his part. While from three to five inches distant from her he begins to wave his plumy first legs in a way that reminds one of a wind-mill. She eyes him fiercely and he keeps at a proper distance for a long time. If he comes close she dashes at him and he quickly retreats. Sometimes he becomes bolder and when within an inch, pauses, with the first legs outstretched before him, not raised as is common in other species; the palpi also are held stiffly out in front with the points together. Again she drives him off, and so the play continues. Now the male grows excited as he approaches her, and while still several inches away whirls completely around and around; pausing, he runs closer and begins to make his abdomen quiver as he stands on tip-toe in front of her. Prancing from side to side, he grows bolder and bolder, while she seems less fierce, and yielding to the excitement lifts up her magnificently iridescent abdomen, holding it at one time vertically and at another sideways to him. She no longer rushes at him, but retreats a little as he approaches. At last he comes close to her, lying flat, with his first legs stretched out and quivering. With the tips of his front legs he gently pats her; this seems to arouse the old demon of resistance, and she drives him back. Again and again he pats her with a caressing movement, gradually creeping nearer and nearer, which she now permits without resistance until he crawls over her head to her abdomen, far enough to reach the epigynum with his palpus". (Pp. 46-47.)

If we lay no emphasis on the implied emotional elements in the behavior of the spiders in this description-terms of emotion borrowed direct from human psychology-there still remain the several types of apparently significant reactions associated with courtship. The statements leave no room for doubt that vision plays an important rôle in the complex reflexes that lead gradually to successful mating. The Peckhams insist that the display of the male is always of a kind to bring before the female the special adornments of the male in whatever part of the body they may lie. The chance of subjective interpretation here is so great that unless the results are carefully checked up by studies of the attitudes assumed by males in species in which the males are without ornament, their interpretation must be taken with the greatest reserve. Assigning, as our authors do, so much by gratuitous implication to the emotional side of the picture prejudices 
one, perhaps too greatly, against accepting a special (even an implied intentional) exhibition of the specially ornamented parts. On the other hand, if it be conceded that the conspicuousness of the male is an element in the reaction, the very special adornments visible from the front might be supposed to enhance the effect produced in the female. Similar displays of special ornamentation in the male have been described both for birds and insects, but here, too, the question has been raised as to whether such exhibitions are more than an accidental accompaniment of the posturing of the male, for the same kind of behavior is known to occur in other cases where the male is unornamented and resembles the female. Had such a male special ornamentation it would no doubt appear to us that his behavior was "calculated" to display his ornaments.

Dr. and Mrs. Peckham point out that their observations are entirely inconsistent with Wallace's interpretation of the origin of secondary sexual characters. They find no evidence in favor of his view that the male possesses greater "vital activity." On the contrary, the female is the more active and pugnacious of the two. They also object to Wallace's statement of a total absence of any evidence that the female notices the display of the male. In spiders the females "observe" the males with close attention during their courtship. They point out also that, in spiders at least, as the female gradually becomes adult, a male if preferred will have a chance of mating with several females, "and as the mating season lasts for two or three weeks the more brilliant males may easily be selected again and again." In regard to Wallace's argument as to the distribution of accessory plumes in humming birds, the Peckhams point out that-

"The pectoral museles reach their highest development in the hummingbirds, the diurnal birds of prey, and the swallows, and we may, therefore, fairly use these groups to test Mr. Wallace's explanation of breast plumes. In the swallows and birds of prey we find no such appendages, in spite of their further claim to them, on the ground of great vigor and activity. As to the humming-birds, we find in the genus Aglacactis six species with more or less developed breast-plumes, which are also found in nine other species, scattered through different genera-in all, only fifteen species out of four hundred and twenty-six; while we find in fifty-six species the lengthened and modified tailfeathers, which, according to Mr. Wallace's view, should be peculiar to the Gallinacex.

"Again, there are elongated feathers from the throat or from the side of the neck in thirty-five species, while seventeen have crests from the top of the head, and seventeen, downy puffs from the tarsi." 1

From this brief survey of the family we see that, contrary to what we should expect from Mr. Wallace's theory, although the breast muscles are the seat of the highest activity, breast plumes are the least frequent of all the forms of ornamental plumage.

\footnotetext{
${ }^{1}$ Loddigesia mirabilis has the tail about three times as long as the body. Similar modifications are found in the genera Sappho, Cynanthus, Lesbia, Stegnura, Discura, Gouldia, ct al.
} 
"We may fairly say, then, that the humming-birds completely refute the proposition that there is any relation between the development of color and accessory plumes and 'surfaces where muscular and nervous development is considerable.' "1

What is true for birds is even more obvious for spiders where the special ornaments are not confined to parts of the body with high muscular development, etc. The writers make the very pertinent criticism that while Wallace objects to assuming the emotional states in females, he is less careful in regard to the males' emotions when he speaks of the display "under the influence of jealousy or sexual excitement .... The males, in their rivalry with each other, would see what plumes were most effective; and each would endeavor to excel his enemy as far as voluntary exertion would enable him." 2

"If the males have so complex an emotion as jealousy, and further, if they are conscious of the value of the plumes, may it not be asked why the female is unable to 'see what plumes are most effective?' The mental state in the male is without meaning unless we suppose the female to be affected and pleased." (Peckham, loc. cit., p. 144.)

In regard to another interpretation of the courtship, the Peckhams point out:

"Mr. Pocock has suggested that the attitude of observant interest on the part of the female spider might be taken to indicate that she was preparing to spring upon her mate and devour him; or that it might simply mean that she was warily guarding herself from his approach. Neither of these suppositions is admissible. In some species the male is not attacked by the female, and when she does wish, as frequently happens, either to avoid or to destroy him, her attitude is totally different. In the former case she turns about and runs rapidly away, or suspends herself by a thread of web. In the second, there is a contraction of all the muscles, the legs are drawn together, and in this crouching position she creeps slowly toward him, as she might if he were a fly, only with something more malignant in her aspect. When she takes this stand the male incontinently flees. When, on the contrary, the female is interested in the male display, she seems perfectly absorbed in watching him, the muscles are all relaxed, unconscious of herself she directs her glance now here, now there, as he moves about; as he continues his mad antics, her appearance gives every indication of pleasurable excitement, and as he comes closer and closer, she yields herself to the impulses which he has awakened in her, and, as in pulex, joins in his dance and whirls around and around as though intoxicated. We claim, then, to have completely answered Mr. Wallace's first objection." (Peckham, loc. cit., pp. 145, 146.)

Finally, in regard to the specific character of the display of the males, the Peckhams make the following significant statement:

1 Among the most remarkable of this wonderful family are the nine species of coquettes (Lophornis), which have elongated feathers, with metallic tips, springing from the sides of the neck; some have also beautiful crests. (George W. and Elizabeth G. Peckham., Additional Observations on Sexual Selection in Spiders of the Family Attidæ., Nat. Hist. Soc. of Wisconsin, 1889, vol. I, pp. 141, 142.)

${ }^{2}$ Tropical Nature, p. 210 . The italics are ours. 
"The spider has four pairs of legs, and all are equally available for display or locomotion, and since all the movements are slow and on the ground they are entirely open to observation and study, and we are thus in a position to deeide by facts whether their aetivity is simply an outlet for superfluous energy, and therefore meaningless, or whether there is a purpose in it. If the purpose of the antics is only to let off energy, then we should expeet one pair to be flourished around quite as often as another, and that the pair flourished should as frequently be one that was not ornamented as one that was; and, moreover, their movements ought not to be of such a nature as to clisplay the color or ornament more frequently than the law of chance would explain. If the spider almost always moves the ornamented legs, and in such a way, too, as to bring out their beauty, it would seem to us, to say the least, highly improbable that the dance of the spider was merely a meaningless overflow of surplus energy. Such an explanation leaves much that needs explanation. The facts are, that the best foot is put forward; and this is just what Darwin's theory requires and explains. Under Mr. Wallace's view the facts are inexplieable. The better to show that these movements are not simply meaningless outlets of high vigor, we illustrate the several positions by figures taken from nature (figs. 7-12). The figures would seem to prove that the legs that are ornamented or contrasted in color are also the legs that are usually flourished; that where none of the legs have special ornament, then all are used; or, as sometimes happens, when an unornamented leg is used the movements are of such a character as to display some ornament that would otherwise have been more or less hidden from the female." (Peckham, loc. cit., p. 147.)

In the tarantula, Petrunkewitsch finds that sight plays no rôle in mating - that it is due entirely to accidental contact between the male and female. Here the sexes are closely alike, except for a pair of hooks on the front legs of the male, by means of which he grasps the mandibles of the female, holding them during the elaborate process of transference to her genital opening the sperm that he has already collected in the genital spoon on his palpi. The hooks serve to guard the male against injury or death, while at the same time they aid him in the act of coitus.

In a common spider, Mavia villata, two kinds of males exist. Both have been seen to mate with the same female. No preference is given to either type. The difference between them, according to Painter, is connected with or caused by an additional pair of chromosomes in the gray male. The two types may therefore have no connection with sexual selection, but be directly due to a difference in the chromosome group.

Montgomery, who made observations on the courting habits of several species of spiders, states that his "general theoretical conclusions were quite different from those of the Peckhams." It turns out, however, that his objection to their view is based entirely on their assumption that the male is conscious of his display and that the female is guided by an esthetic sense in selecting the more beautiful male. It should be pointed out that even after the removal of these 
gratuitous assumptions as to the cause of the evolution of the male and female, enough still remains in Montgomery's own observations to include his results on courtship under Darwin's theory of sexual selection. For example, Montgomery says:

"The adult male is excited simultaneously by fear of and desire for the female, and his courtship motions are for the most part exaggerations of ordinary motions of fear and timidity. By such motions he advertises himself to the female as a male, but there is no proof that he consciously seeks to arouse her eagerness by esthetic display - there seems to be no good reason to hold that the female is actuated in her choice by sensations of beauty. . . . Thus my opinion was opposed to Darwin's theory."

Now, it is obvious that if a more brightly colored male has a better chance of "advertising himself" to the female all the essential requirements of Darwin's theory are fulfilled, regardless of whether the male is conscious of his ornamentation or the female makes use of an "esthetic sense." In another passage (p. 173) Montgomery concedes all that any modern critical advocate of Darwin's theory is likely to ask:

"We have previously seen that conscious aesthetic choice by the female probably does not account for such male characters [secondary sexual characters with their 'conspicuous color markings']; that they are accordingly, probably not due to sexual selection. These characters of the males may be most readily explained as being conceived by simple natural selection. Peculiar ornamentation would be selected because unusually greater sex recognition therefore prompted mating."

It is evident that Montgomery has only shifted the situation, although to advantage, I think, but is essentially in accord with Darwin's theory of sexual selection, despite his protest to the contrary. The difference lies in Darwin's and especially in the Peckhams' use of the term "choice," "aesthetic sense," etc., to stand for the fact that the female more promptly mates (as Montgomery prefers to put it) with a male peculiarly ornamental.

The most critical observations on sexual selection that have been made in the group of insects are those by Sturtevant on the pomace fly. The courtship is described as follows:

"The first and most noticeable act in courtship occurs when the male, being near the female, extends one wing at about right angles to his body, and vibrates it for a few seconds. The wing is then returned to the normal position and the process is repeated, usually with the other wing. But between times there is a scissors-like movement of the wings repeated several times. This vibrating of the wings is often repeated many times, and may be done in any position relative to the female, though the male always faces her. Usually, in fact, he swings quickly around her in a semicircle once, or oftener, during the process. Soon the male begins to protrude his genitalia and, if the female remains quiet, to lick her posterior end. Some white matter now protrudes from her ovipositor, and other males in the same vial are usually observed to become excited now and begin courting, indicating odor as a cause of sexual excitement. If the female runs or flies away the male is excited, moves his 
wings jerkily, and walks around rapidly, but seems unable to follow the fernale accurately or to locate her quickly. The penis is direeted forward by bending up the abdomen underneath, towards the thorax, and is jerked toward the female (the male always standing facing her at this stage), but not always toward her genitalia, as I have seen it strike her in the eye. (The male in this case, however, had white eyes, and so was perhaps blind. Normally the aim is accurate.) If it does strike the mark the male mounts on the female's back, between her wings. Mounting never takes place until after the actual copulation has occurred, in which respect Drosophila differs from some related flies (e. g., Muscidæ, Anthomyidæ, Sepsidæ, Borboridæ, and Ephydridæ, so far as my observations go). In these forms the male flies and lights on the female, after which copulation may or may not take place, probably depending upon the way the female responds." 1

To test whether the wings have any significance in courtship, the wings of a male were clipped off and he was put into competition with a normal male of the same stock, age, and size. A virgin female sexually mature was given to these two males. The normal male mated 72 times before the other, the clipped male 53 times. It might appear that the female selected the normal male in preference to the clipped one, or possibly that the male with normal wings drove the other male away. That the operation on the wings may have an influence on the male himself is shown in McEwen's results. He found that clipped males lost their heliotropism. It was also possible that the courtship of the normal male might make the female ready to copulate and then she would mate with either male. Sturtevant tested the last supposition by placing single pairs in vials, testing each day an equal number of normal and clipped males. The length of time before copulation was noted. The clipped male began to court as soon as the normal, but a larger number of normal males mated in the first 12 minutes than clipped males (59 to 25). Had the females discriminated against the clipped males to an equal extent we would have expected a much greater excess than 72 to 53 when they were in competition. It appears, then, that the wings are useful in shortening the time between the meeting of the individuals and copulation. The display acts, however, almost as favorably for the other male as for the exhibitor himself. The results show, therefore, that here an esthetic sense of the female need not be postulated, for she actually shows little preference when she has been brought to the point of mating between the male that aroused her and the other male that did not. This critical test puts the problem in a different relation from that which Darwin's theory of female choice was meant to throw light upon.

The reverse experiment-a elipped and a normal female of the same age, size, etc. - showed that the male did not discriminate between them, for in 52 first trials the normal female was paired with 25 times, the clipped 27 times.

\footnotetext{
A. H. Sturtevant. Experiments on Sex Reconnition and the Problem of Sexual Selection in Drosophila. Journ. Animal Behavior, Sept.-Oct. 1915, vol. 5, No. 5, pp. 352, 353.
} 


\section{PART III. \\ THE GENETIC AND THE OPERATIVE EVIDENCE.}

The genetic and operative evidence shows that there has been included under the general term "secondary sexual characters" a complex of cases that are the outcome of diverse physiological processes. Sex-linked and sex-limited characters have often been confused; some characters depend on the gonad; some of these involve the ovary, others the testes. Still other characters fall under none of these groups, but are the direct product of the male or female genetic constitution. It is not surprising, therefore, that theories proposed on the information derived from certain of these data are controverted by information derived from other data. The theory of sexual selection, in its attempt to bring all the facts under one point of view, has not escaped these difficulties, even although it may be said that neither natural selection nor sexual selection is concerned with the origin or even the kind of variations with which it works. Nevertheless, the latter theory, by ignoring the origin or the physiological process concerned in the production of secondary sexual characters, may make assumptions that are difficult to harmonize with the facts in the case, and we shall find several instances of this sort. For example, if the hen had selected the cock for his fine plumage (which, as we have seen, depends in part on autosomal genes producing their effect without the cooperation of the testes), she would be expected to endow herself with the same adornments (if her selection worked), unless her ovary were already producing some substance inimical to those that she is "calling forth" by selection of the male. The problem is evidently, then, more complex than appears on the surface, and is not so simple as it seemed when these essential facts were unknown or ignored.

In the case of other theories, such as those of Wallace and of Cunningham (that appeal more directly to the causes that are producing the variation out of which the secondary sexual characters are built up), the absence of information, physiological or genetic, has only too often given these writers the opportunity to speculate without the restraints which a more recent knowledge of the facts has imposed on us.

It is obvious from what we have learned that we shall have to proceed with more caution in disentangling the evidence before we can hope to "explain" it. Despite the meagerness of our present information, enough has been found out to indicate that we must be content for a while with tentative and partial explanations even in the bestknown cases, and we must, I think, be prepared to admit that no one theory may be able to account for all of the secondary sexual differences that exist between the sexes.

The genetic evidence shows, in the case of cock-feathering versus hen-feathering in birds, that only one or two Mendelian factor differ- 
ences are involved. The result may seem to mean that the secondary sexual characters themselves have been acquired historically by a single evolutionary step, and that in consequence the opportunity for selection to have accomplished such a result has been enormously facilitated. Such an argument rests, however, as we know to-day, on a false interpretation of Mendelian heredity. What the evidence really shows is that one or two genes if present cause the testes to produce some substance that prevents the cock-feathering from developing. The genetic complex may require a hundred or a thousand or more special factors that are directly and indirectly concerned with the development of the cock-feathering, but one or two other factors may suffice to block this machinery; or, to change the metaphor, these dominant factors may be no more than so much sand poured into the clock. The clock may have been slowly built up historically by many contributory "factors," but a little sand may spoil its activity. Similarly in the hen something produced by the ovary prevents the fullest possible genetic action from taking place. Here at present we do not know whether a single factor or a hundred "special" factors are necessary to produce such an inhibition, but if, as one would like to suppose, it is the same or partly the same genes involved in the ovary, and in the testes of henfeathered males, then a relatively few, one or two, factors will suffice to bar cock-feathering from the female.

In a case like the clover butterfly, where the genetic relations work out on the theory of one pair of factors that produce two types of females and one type of male, it seems more reasonable to infer that such a difference has not been slowly acquired by many smaller mutational changes, because the two types are not adapted to live under two different environments for which their differences fit them respectively, but to live in the same environment. It has never been claimed, so far as I know, that these two types of females have arisen through some males preferring one, some another kind of female, so that even although it may seem probable that the genetic situation is simple, the simplicity can not be turned to the advantage of the theory of sexual selection. It is unnecessary to discuss further the origin of the factor or factors suppressing the development of one type in the male or the probability of the multiplicity of such factors. In the case of such species as Papilio memnon and $P$. polytes, with three types of females, the situation is the same as above, with the addition of the theory of mimicry, that "explains" some advantage accruing to each type of female. Since the latter is only a form of natural selection, we are not further concerned with the change here. Punnett's excellent. treatment of the problems involved in his recent book on mimicry brings the subject down to date.

Meager as is the genetic and surgical evidence at present, it is enough to show that only by further work along these lines can we hope to lay 
a firm foundation for a scientific study of the subject. It is equally important that critical evidence be obtained in regard to the effect on the female of males of different types in competition. The instinctive reactions of animals in these respects, their first reaction, the associations that may or may not result, are practically an open field for investigation. The entire equipment of human psychology of the introspective school, that has been appealed to for help in a situation itself little understood, reads often more like fiction than like science.

So far as one branch of the subject goes - the possible interpretation of ornamentation in the male-there seem to be two ways at least in which the subject calls for immediate investigation: First, if it can be shown that, other things being equal, a more adorned male rouses the female to prompter mating, it may be inferred with some probability that in the long run such conduct would lead to the establishment of the more effective individual, but this would not be true unless the males mate, as a rule, more than once, for any advantage that might accrue to a more ornamented male would not affect the course of evolution of the species if every other male found a mate too. Second, if it could be shown that the special ornamentation of the male is only one of several effects of a gene whose main effect is in some other direction, then the advantage gained through natural selection in this other direction would carry in its wake the advance in ornamentation, and if the change affects one sex more than the other, owing to the difference in the genetic complex of the two sexes, it would be called a secondary sexual character.

\section{A. Evidence from Mammals.}

Owing to the differences in the secondary sexual characters of different breeds of sheep, we have more genetic information about such characters in this group than in other groups of mammals. Fortunately, also, in some of the breeds both castration and ovariotomy have been performed, and consequencely we are in position to utilize both sources of information for interpreting the situation. In certain breeds both males and females have horns (Dorsets), in which case the horns of the male are larger than those of the female. In other breeds neither males nor females have horns (Suffolks). In still other breeds the males have horns and the females are hornless (Merinos and Herdwicks). The clearest evidence that we have, both genetic and operative, is that obtained by Woods, as reported by Bateson, in which horned (Dorsets) and hornless (Suffolks) breeds were crossed. In the Dorsets, where both sexes have horns, those of the male are larger than those in the female. When the young male is castrated the horns develop, but only as far as in the female. It appears, therefore, that the presence of the testis, probably through some secretion from it, 
contributes to the development of the horns. The other race, the Suffolks, have no horns in either sex. Castration produces no change in their hornless condition.

When a Dorset ram is crossed to a Suffolk ewe the sons have horns, the daughters lack them. The reciprocal cross gives the same results. The factor or factors involved are therefore not sex-linked. When the $F_{1}$ 's from the cross or from its reciproeal are inbred, four classes of offspring are produced, namely: Horned male, 3 ; hornless male, 1 ; horned female, 1 ; hornless female, 3 . The ratios, as above, are approximately $3: 1: 1: 3$.

A simple Mendelian explanation covers the results. If we assume that the Dorsets, both male and female, are homozygous in a factor for horns, $\mathrm{H}$, that is not in the sex chromosome, and that the Suffolks "lack this factor," $i$. e., that they have an allelemorphic factor for hornlessness, the germ-cells are $\mathrm{H}-\mathrm{H}$ and $\mathrm{h}-\mathrm{h}$, respectively. Only one kind of individual, $\mathrm{Hh}$, results in $\mathrm{F}_{1}$. Since the male with this formula develops horns, we must conclude that the presence of the testis (through its secretions) causes horns to develop, while in the female of this same composition horns are not produced because of the absence of the testes. The sex-cells in these $\mathrm{F}_{1}$ individuals are $\mathrm{H}-\mathrm{h}$ and $\mathrm{H}-\mathrm{h}$. Chance meeting of these gametes will give 3 classes of individuals, irrespective of sex, namely, (1) HH, (2) Hh, (1) hh. The expectation for the males is that those of the composition (1) $\mathrm{HH}$ and (2) Hh will develop horns, while those of the composition hh will not develop horns. There should be 3 horned to 1 hornless male. In the females we expect those with the composition (1) HH to develop horns, since they have the same formula as the pure Dorset; those with the formula $\mathrm{Hh}$ are not expected to develophorns, because the $\mathrm{F}_{1}$ females of this composition do not have horns; those with the formula hh are not expected to develop horns, because they have the same composition as have the pure Suffolk. There should be 3 hornless to 1 horned female. Combining both sexes, the expectation for $\mathrm{F}_{2}$ is 4 horned to 4 hornless. Arranged according to sex, these give the classes realized: Horned male, 3 ; hornless male, 1 ; horned female, 1 ; hornless female, 3. That this is the correct explanation is borne out by back-crossing the hornless $F_{1}$ female to a hornless Suffolk ram. The former has two kinds of gametes, $\mathrm{H}$ and $\mathrm{h}$, the latter only gametes that bear the $\mathrm{h}$ factor. Half the sons should be horned, half hornless, because half of them are $\mathrm{Hh}$ and half $\mathrm{hh}$. But none of the daughters should have horns, because neither the Hh nor the hh females produce horns. This is the result realized, viz, 3 hornless offspring to 1 horned.

The preceding account of the inheritance of the factor for horns is based on the combination of Dorsets and Suffolks used by Wood. That other conditions may exist in other breeds and even in races of 
the same breed is claimed by Arkell as a result of a large number of crosses that he has carried out. He states, for instance, that in the great Merino class, with its various sub-breeds, there are flocks in which the males only are horned, but even here there may be individual males that are hornless "and at times the females may also show some signs of horn growth." In America, Arkell states, there are three types of Merinos-the American, the Delaine, and the Rambouillet. He quotes Plumb (Types and Breeds of Farm Animals, Boston, 1906) as stating that "the American Merino ram carries heavy, spirally twisted horns, but the ewes are hornless; . . . . that the rams of the National Standard or Victor-Beald Delaines may or may not have horns; that the Dickinson Delaines may have small horns, but a polled head is preferred," etc. These conditions suggest that there may be more than a single factor for horns in sheep or that there may be modifying factors in certain breeds. In fact, Arkell and Davenport attempt to cover the results of Arkell's experiments by assuming that there is an inhibiting factor for horns that is carried by the sex chromosome. Such an inhibitor (I) would be double in the XX female and single in the $\mathrm{X}$ male. It is assumed to be incapable of preventing the development of horns in the heterozygous $\mathrm{Hh}$ male, the inhibitor being there simplex (i.e., one I), while the double inhibitor is capable of preventing the horns in the heterozygous $(\mathrm{Hh})$ condition, but not of preventing the development of horns when the homozygous $(\mathrm{HH})$ condition occurs. There are several objections to this scheme: first, that there is no evidence that a sex-linked inhibitor is present that affects the hornless breeds, for the evidence indicates rather that there is no factor for horns present in them, at least in the Suffolks; second, the peculiar balance between the factors for horns and the inhibitor seems an extremely artificial statement. Arkell and Davenport intimate that races with horned males and hornless females do not exist in a pure state. That breeds impure in these respects may exist need not be denied, but that pure races for such a dimorphic condition do exist seems probable. Castle states, for instance, that he knows at first hand of such races of Merinos. Castle also states that castrated Merino rams in this race do not develop horns, and this result is in accordance with statements made by Marshall for Herdwicks (a race with horned males and hornless females). Under the circumstances it is certain that the presence of the testes is one of the factors in determining whether horns develop at all (as in Merinos), or in determining the extent to which they develop (as in the Dorsets), rather than that the difference between the sexes is due only to an inhibiting genetic factor. Nevertheless, it may be well to keep open the possibility that there may be different factors for horns in different races (allelomorphs or others), or conversely, that the genetic composition of the races is different, the factor for horns remaining the same, but producing a different effect. 
It may be pointed out in passing that if, as Arkell assumes, the hornless races are due to the presence in them of an inhibitor for horns, the results can be worked out without postulating that the inhibitor is sex-linked. For example, if the hornless male and female be HHII and the horned male and female HHii, the $\mathrm{F}_{1}$ horned males and hornless females will be HHIi. The germ-cells will be $\mathrm{HI}$ and $\mathrm{Hi}$ in each sex, which, by chance meeting, as shown below, gives the results obtained by Wood. Thus:

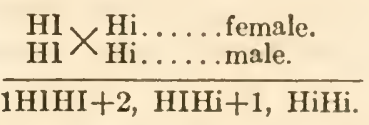

These formulæ give 3 horned males, 1 hornless male, 1 horned female, 3 hornless females. This formulation, while appealing apparently to a different set of factors from those used by Arkell, is in reality the same in principle, since the heterozygous condition is here represented by $\mathrm{Ii}$ (instead of $\mathrm{Hh}$ ) and sex determines that the heterozygous male is horned and the female hornless.

The genetic relations of the Merino with horned males and hornless females to the Dorsets, in which both sexes are horned (but in the male the horns are larger), must be different from the genetic relation in the other cross. There are two theoretical possibilities, viz, that a different factor for horns is present that is either an allelomorph or another different factor; or second, that a modifier is present in the Merino that keeps down the development of the horns in the female. An answer could be obtained by breeding Merinos to horned and to hornless and getting $\mathrm{F}_{2}$ from both crosses. Arkell's data is not sufficient to settle the question, because his numbers are often too small, but chiefly because it appears that there were two genetic types present in his flock of Merinos, one of which is characterized by scurs (very short horns) in the females, the other by hornlessness in the female. He found in a cross between a hornless father and Merino mother (that had knobs or scab-like growths) that the daughters had horns or scurs and carried a determiner for horns (as subsequent generations showed). On the other hand, in other cases where the Merino mother was without horns, her $F_{1}$ daughters had no horns. In both cases the $\mathrm{F}_{1}$ sons had horns. Arkell cites this cross as "proving" that the knobs of Merino ewes depend for their development upon two horn determiners $\left(\mathrm{H}^{\prime} \mathrm{H}^{\prime}\right)$. It is not at all evident that the results lead to such a conclusion, as other explanations will cover the case as well.

Arkell's mating between Dorsets and Merinos (tables $I x$ and $x v r$ ) corroborates his view "that the knob of the Merino female is represented in the germ-plasm by the double determiner." The $5 F_{1}$ sons had long horns, $3 \mathrm{~F}_{1}$ daughters had horns present, and 2 had them absent (table xvI). If some of the Merino mothers used were homozygous for a factor that inhibits the development of horns in the female 
we can account for the hornless daughters, and if other mothers did not have this factor (or were heterozygous for it) we can account for the horned daughters. Evidently more evidence is needed. Arkell himself assigns a corresponding difference to the mothers in these cases, based on the observed fact that the mother that had knobs or scurs were the ones that gave birth to the horned daughters. If the above suggestion proves true, it shows that the Merino condition dominates the Dorset condition. The result is in harmony with the view that both have a common factor for horns, but that in addition the Merinos have a non-sex-linked modifier that holds down the development of the horns in the ewe.

What bearing have these results on the theory of sexual selection? Clearly the Merino male, as constituted at present, develops horns because he is a male, but only in the sense that his testes secrete some substance that makes his horns grow. That maleness does not in itself necessarily produce horn is shown by the absence of horns in the Suffolk breed. Is it the same factor, present in the Merino, that produces horns in both sexes of Dorsets when homozygous and in the male only when heterozygous? If originally the ancestral race had no horns, the appearance of factors for horns would, even in a heterozygous condition, have sufficed in the males for the development of horns. If this gave them any advantage either over the enemies of the race or in the eyes of the female, such factors might be perpetuated, and through transferrence to the females ultimately become homozygous in both sexes. Both would then have horns, whether horns were or were not of any advantage to the female, which would have them because they have an advantage to the other sex.

Because the genetic evidence shows that a single factor difference between the breeds with and without horns accounts for the horned condition in one of them, it by no means follows that horns as they exist arose as a single mutant factor change. True, they may have arisen as a new single factor difference, but the Mendelian evidence can not be claimed as evidence for this view. The a priori argument based on the relation of horns in an adaptive sense to the rest of the body would appear rather to indicate that they could not have arisen at a single mutational step.

Concerning the still broader bearing of this evidence on the theory of sexual selection, two distinct questions are involved: first, how has the present racial difference in horns arisen in domesticated sheep, and secondly, what was the original condition of sheep. Reversing the order of these questions, we find that sheep were domesticated in Asia and Europe before the dawn of history. "Whether our well-known and useful animal is derived from any one of the existing wild species, or from the crossing of several, or from some now extinct species, is quite a matter of conjecture" (Flower and Lydekker's "Mammals"). 
Most of the wild species of the genus (of which about 12 are recognized) have horns in both sexes, but larger in the male. There are 3 wild species in which the horns are lacking in the female, according to Flower and Lydekker. If these have been crossed into the domesticated breeds the condition shown by the Merino may go back to the wild state. The third condition found in domesticated races, viz, hornlessness, may have appeared under domestication. Such a change might have arisen in either of the two other types and would be comparable to well-known losses of characters shown by domesticated animals and plants. These losses of characters are usually ascribed to actual losses of genes; any lost gene in the complex of factors necessary for the production of horns might cause such a change. But there is no advantage, in fact, in ascribing the loss in the character to a loss in one of the factors producing that character, for any change of any kind in the factor complex might bring about the same result and the evidence from multiple allelomorphs should put us on our guard against the all too easy assumption that a loss in a character involves necessarily loss of a factor in the real sense in which loss is used in ordinary speech.

The operative and genetic evidence for sheep shows that if the horns in the male were developed through natural or sexual selection we should expect them to develop also in the female. The greater development in the male seems to be due to secretions from the testes which probably are due to special factors that call them forth, but whether such factors were also acquired to reinforce the effects being produced through selection or were already present (reinforcement for horns being only a by-product of their activity) can not of course be known. We can suppose that special factors that suppress the development of horns in the female may have arisen in the wild or in the domesticated races and have been perpetuated because of some imagined benefit conferred; or that in certain races factors were already present that kept down the development of horns in the female. In any ease such factors do not cause their effects through secretions from the ovary, because after ovariotomy horns do not develop; nor are they sexlinked factors. Any speculation as to how natural or sexual selection has brought about the evolution of the horns in sheep must reckon with the conditions imposed on such speculation by the preceding information. So far as I can see, it leaves the situation in this respect neither better nor worse off than before.

In deer the effects of castration are well known, but there is no genetic evidence to show the kind of factors involved, since no crosses have been made between species with differences in their horns. If the young male deer is castrated before the antlers have appeared, no horns develop. If castrated at the time when the antlers have begun to develop, incomplete or imperfect development follows. The antlers 
remain covered with the velvet, and are said not to be thrown off periodically as in the normal male. If the adult stag with antlers is castrated, the horns are precociously dropped, and, if replaced at all, the new antlers are imperfect and are not renewed. I do not know of any cases in which females have been spayed, but no doubt the ovaries must sometimes become diseased. There are, however, a few records of horns developing in this sex in old age, or presumably after disease of the ovaries. Both male and female reindeer are horned. Castration produces no effect on the development of the horns.

In the case of deer it is evident that the presence of the testes in the male causes the horns to develop. The genetic factor, or factors, for horns may be supposed to be carried by both sexes, but the effects of the factor can be seen only when the testes are present. In the reindeer and eland, on the other hand, the genetic factor for sex can produce horns without the need of the environment produced by the testes. ${ }^{1}$ Whether we are dealing here with the same factor or whether the rest of the hereditary complex makes the result different can not be known without breeding experiments.

There is apparently a connection between the stage of development of the horns and the age of the animal, as the following statement by Yarrell $^{2}$ (1858) indicates:

"The fallow-buck is at his best in his sixth, or at most in his seventh year; after which, though the carcass may increase, the horns become smaller, and irregularly going back annually through something like their former stages of increase, a very old buck has from the state of his horns been mistaken for a young one. In the osteological department of the Museum at Paris there was, and may be now, the skeleton of a female reindeer in which the horns were reduced to little more than a rudiment of the beam and the brow-antler; this animal was so old that the molar teeth were worn down to the edges of the alveolar cavities."

At first sight these results in the fallow deer appear to be only an age condition, but since in old age a reverse process sets in, it may appear more probable that the amount of secretion by the testes or other glands may be the conditioning agent. In the case of the reindeer one may hesitate to ascribe the change to the ovary without further evidence.

In cattle the effects of castration as seen in oxen have been studied. There is little here that is useful for our present purpose. The horns are not inhibited and may even be larger than in the bull. The absence of horns in certain races of cattle is apparently a dominant character, but as the character is neither sex-limited nor sex-linked, the evidence has no further bearing on the present topic.

\footnotetext{
${ }^{1}$ In the eland as well as in the reindeer, in which both sexes have horns that begin in the latter at least to develop before the gonads ripen, it is stated that castration does not prevent the development of the horns in the male, but whether they are as large as in the normal male is apparently not definitely stated.

2 Yarrell also states that after the fallow buck has reached the height of its maturity and has 6 prongs in its antler, removal of one testis causes the next antler to have but 5 prongs.
} 
The effect of removal of the ovary from female calves has been studied by Tandler and Keller. The height of the ovariotomized female is less than that of the cow. The same difference is found between bull and ox. Tandler and Keller call attention to the similarity of the head in male and female lacking the gonads. They conclude that the ovariotomized female does not come to resemble the male, but that removal of the gonad causes both sexes to converge to a common type.

Castration is frequently performed in horses, dogs, and cats, but as the secondary sexual differences, aside from size and behavior, are not very well marked in these animals, the results need not be here considered.

Steinach's experiments with rats are important, because by grafting ovarian tissue into the castrated male, the male was caused to assume certain characteristics peculiar to the female. The mammary glands that are rudimentary in the male became much enlarged-not only the glandular tissue increased in amount, but the mammæ themselves were greatly developed. The hair of the male is coarser than that of the female. In the feminized male the hair was soft like that of the female. The size was smaller than that of the male. The skeleton also was affected, and Steinach thinks that it changed in the direction of a female skeleton. Even more striking was the sexual behavior of the feminized rat. The individual no longer reacted as male, but showed some of the reflexes peculiar to the female. These results, that stand almost alone, appear to show that several of the secondary sexual characters of the female rat are due directly to the presence of the ovary.

One of the most striking and definite results shown by castrated rats (Steinach), guinea-pigs (Pirsche, Steinach), rabbits (Pauncet), hedgehog (Marshall), and man is to be seen in the effect on the accessory glands connected with the male ducts as well as on the penis. These remain small and infantile. Some substances produced by the testes are essential for the development of these parts. Natural selection rather than sexual selection would be the agency that here comes into play.

In man the effects of castration have been often described. Eunuchs have had a commercial value in some countries, as in Turkey and China, and castration has been deliberately practiced on young children. Certain religious sects, such as the Skops of Russia, have advocated and carried out the operation. Disease has also at times necessitated the removal of the testis, more often in adults than in the young. The full effects are shown only when the operation has been carried out before the secondary sexual characters have developed. The more striking difference between the sexes involve the beard, and the hair on other parts of the body, the voice, the shape of the pelvis, and the mammary glands. For a detailed account of the results, the publications of Tandler and Grosz and Marshall's book on the "Physiology of Reproduction" should be consulted. 
The two most obvious changes in the eunuch are the absence of the beard and mustache and the small larynx, which produces a highpitched voice. In both these respects man differs from woman; in both, however, the eunuch is like the boy as much as he is like the woman. It is not evident, therefore, whether the eunuch has retained the juvenile condition or has become more like the female. Moreover, there is the possibility that there is no difference in the present case between these two conditions. The distribution of hair on the pubis of the eunuch is often said to be more like that in the woman than that in the man, but there is apparently no sufficient evidence to show that this is more than the juvenile condition or an undeveloped condition of the male. As to the voice, there is no way of determining whether the voice of the eunuch is feminine or juvenile. The development of the mammæ in the eunuch would be a better test, but it does not appear from theliterature on the subject that the mammary glands and the nipples of the eunuch are changed toward the female type. On the contary, it appears rather that there is no such change. It is true that the tendency toward the accumulation of fat may give the eunuch a somewhat feminine appearance (since one of the foci of fat accumulation is in the region of the breasts), but this in itself can scarcely be claimed to be feminization, but due rather to the more slothful habit of the eunuch that tends to obesity.

A more suggestive resemblance is found in the narrowness of the shoulder girdle and broadness of the hips in the eunuch, but even these rsemblances to the female should be regarded skeptically, since other changes in the bones that result from castration are certainly not a development toward the female type, but a peculiar specific effect of the absence of testes on the growth of the bones. For instance, the bones of the arms and legs are much longer in the eunuch than in either the normal man or woman, in fact, more in the direction of the male, who has longer legs than the female. The explanation usually given is that the ossification at the ends of the bones and of the epiphyses does not take place so soon as in normal men and women. The condition here is that characteristic of the juvenile state that is carried over into the adult, but whether the narrowness of the chest and shoulder girdle of the eunuch is correlated in some way with the more prolonged growth of the other bones has not, so far as I know, been determined. That there is no apparent connection between the shortness of the one and the greater length of the other does not necessarily lead to the conclusion that there is no such connection. For the present I think we must hold this point in reserve.

Steinach's evidence for the feminized rats, if it may be extended to man, indicates that some of the female characteristics are due to the presence of the ovary holding in check the genetic possibilities of the female, as well as leading to the development of such characteristic 
traits as the mammæ, etc. In the case of the pelvis the female departs from the juvenile type of both sexes, and here one might look for a better criterion. It is stated that the pelvis of the ox is more like that of the female than it is like that of the male, and it has been said that this is true for the castrated rat and guinea-pig, but whether a simple enlargement of the juvenile pelvis would make it resemble the female type more than that of the male has not, so far as I know, been carefully examined. Should it prove here that this is the case, the evidence on this point would be no stronger than that for other character differences. As has been stated, Tandler and Grosz think that the changes in the skeleton of the ox, as well as those in the castrated cow (skull, pelvis, and limb bones), are due directly to loss of the gonads and are much the same in both. But their resemblance may possibly be due more to an enlarged juvenile condition rather than that either of them changes toward the normal skeleton of the other sex.

The statements that have been published concerning the effects of removal of the ovaries in woman are, on the whole, unsatisfactory and often contradictory. That the uterus and oviducts become smaller is expected from what is known to occur in other mammals, and is definitely recorded in the human female. That the breasts become smaller is stated to be the case, but whether because of an actual decrease in the glandular portion has not, so far as I know, been shown. That hair is likely to develop on the upper lip of woman without ovaries is also claimed as likely to occur, and this, too, is sometimes seen in old women, but if it is interpreted to mean an approach to the bearded condition of man it should be admitted that the development is hardly sufficient to invite such a comparison. Finally, it has been stated that the voice becomes decper, more, therefore, like the male, but this has also been denied. If it could be established that the voice changes and that it was brought about by an enlargement of the larynx, similar to that which takes place when the larynx of the boy changes to that of the man, it might seem not improbable that the change was toward that of the opposite sex. This would mean that the ovary produces some substance that prevents the enlargement of the larynx in the female. But since it has been shown that the enlargement in the male is caused by the development of the testes, and that this enlargement is prevented by castration, a paradoxical situation would present itself, viz, that the testes eause the larynx to enlarge in the male and the ovary prevents the enlargement in the female. Until convincing evidence is fortheoming, the question is better left undecided.

B. Evidence from Birds.

Probably a greater difference in the secondary sexual characters is shown in birds than in any other group. It is true that there are 
species, such as the doves and pigeons, in which the plumage of the male is much like that of the female, but this is the exception rather than the rule. At the other extreme are species like birds of paradise, hummingbirds, fowls, pheasants, ducks, and many passerines, in which the plumage of the two sexes is entirely different. Our knowledge as to the relation between the nuptial plumage of the male and the condition of the sex-organs rests largely on information gained by castration in poultry and ducks and on the assumption of the nuptial plumage in several species only at the mating season.

John Hunter in 1780 described a pheasant with male plumage. His account of a similar change in a pea fowl is so complete that I venture to quote it in full:

"Lady Tynte had a favorite pyed pea-hen, which had produced chickens eight several times; having moulted when she was about eleven years old, she astonished the lady and her family by showing the feathers peculiar to the other sex, and appearing like a pyed peacock. In this process the tail, which was similar to that of a cock, first appeared after moulting. In the following year she moulted again, and produced the same feathers. In the third year she did the same; at the same time she had spurs similar to those of a cock. She died in the following winter during the hard frost, namely, in the winter 1775-6. She never bred after this change in her plumage. This bird is now preserved in the Museum of Sir Ashton Lever." 1

"From what has been related of these two birds, may it not reasonably be inferred that it seems probable that all those wild pheasants of the female sex, which are found with the feathers of the cock, had changed the nature of their feathers, particularly at a certain age?

"If this idea be just, it shews that there is a disposition in the female to come nearer and nearer to the male, at least in the secondary properties; or it may rather be said that the female is later in producing this change than the male is; for it has already been observed that both sexes when young differ not from each other in these respects, but that the male appears to be the one that by degrees separates from the female in its secondary properties."

Statements in regard to the effect of castration on poultry go back, it appears, to Aristotle. Yarrel in 1811 and again in 1850 has given an excellent account of many of the effects produced. His account of the effects on the cock seem to be based partly on hearsay, and while they contain much accurate information, yet the statement that the plumage of the capon is intermediate between that of the cock and hen is incorrect. The further statement that by cutting the oviduct the hen assumes the plumage of the capon has been shown by Sellheim to be erroneous. The operation referred to by Yarrel must have been one in which the ovary was removed.

\footnotetext{
${ }^{1}$ It might be supposed that this bird was really a cock which had been changed for a hen; but the following facts put this matter beyond a doubt: First, there was no other pyed pea-fowl in the country. Secondly, the hen had knobs on her toes, which were the same after her change. Thirdly, she was as small after the change as before, therefore too small for a cock. Fourthly, she was a favorite bird, and was generally fed by the lady, and used to come for her meat, which she still continued to do after the change in the feathers.
} 
Yarrel described a female pheasant that had assumed some of the characteristic colors of the male. On dissection he found that the ovary was diseased as well as the oviduct. He correctly assigns the change in plumage to the condition of the ovary. He states furthermore that most of the female pheasants that he had examined that had male plumage had not assumed the complete coloration of the male. In one case, however, a complete change had taken place. The change in pheasants he thought was due to old age accompanied by partial or complete loss of function of the ovary. For poultry he states:

"In the imperfect female the comb increases; a short spur or spurs appear; the plumage undergoes an alteration, getting what is usually called "foulfeathered;' she ceases to produce any eggs, and makes an imperfect attempt to imitate the crow of the cock. Being profitless in this state, she is usually made away with. The proverb says:

A whistling woman and a crowing hen

Are neither good for gods nor men.

Our neighbors and allies the French, who seem to take a wider range in their prejudice against habits which they consider irregular, have the following proverb, which says:

Poule qui chante, Prêtre qui danse

Et Femme qui parle latin,

N'arrivent jamais a belle fin.

"I have seen two instances in which females of the wild duck have assumed to a considerable extent the appearance of the plumage of the mallard, even to the curled feathers of the tail. One of these birds, in my own collection, was given me when alive by my kind friend the late John Morgan, esq. When this bird was examined after death, the sexual organs were found to be diseased, as in the case of the hen pheasants referred to, and figured in the $2 \mathrm{~d}$ volume of the History of our British Birds. In the published illustrations to his Fauna of Seandinavia, M. Nilsson has given a colored figure of a duck in this state of plumage (plate 163), which is called a barren female, and in which the curled tail-feathers are made very conspicuous.

"From the general similarity in these females to the appearance assumed for a time by healthy males in July, I am disposed to refer this seasonal change in males, in this and in other species of ducks, to a temporary exhausted state of the male generative organs, and their consequent diminished constitutional influence on the plumage.

"A male shut up by himself from early spring to the end of July undergoes no change in his plumage; but if he is allowed to associate with females till their season of incubation commecnes, he then goes through the change, and this appears to indicate the eause of the partial summer moulting.

"The appearance is somewhat different, but yet very interesting in insects and crustacea. In these classes the sexual organs are double and distinet, arranged one on each side of the elongated mesial line. It sometimes happens, that a species in which the sexes are of a different color, or markings, or form has one sexual organ of each sort, male and female, in which case each half of the same insect is developed under the exelusive influence of the sexual organ on its own side. Instances are preserved among our collections of butterflies, mothes and beetles; and I have seen it twice in the common lobster. 
"Nor is the human race exempt from the operation of the law which prevails in the Mammalia. In women, at an advanced age, hair appears on the chin and upper lip, and the voice alters, becoming deep in its tone. The beard in old men becomes thin and soft, and our own inimitable Shakespeare has told us,

$* * *$ his big manly voice

Turning again toward childish treble, pipes

And whistles in his sound.

Gurney (1888) has recorded several cases in which female birds have assumed male plumage. For instance, he describes a female merganser, Mergus serrator, assuming male plumage that showed no signs of disease in the ovary. Mr. Cecil Smith had a female widgeon (Mareca penelope) on his ponds near Trenton, which assumed the male plumage some years ago, and which, so far as he knew, had not had young nor laid eggs.

"On May 16th, 1887, a chaffinch (Fringilla colebs) in full male plumage was shot at Chapel Town, near Leeds, in Yorkshire, by the son of Mr. W. L. Jackson, M. P.; it was skinned by G. R. Grassham, assistant to Mr. W. E. Clarke at the Museum, who, much to his surprise, found that it was a female, and contained an egg, ready for laying, of a pale blue, without markings, and another egg in a less forward state. This chaffinch is in every way in perfect male plumage, and I am indebted to Mr. Clarke for his kindness in sending these particulars with the specimen, which he received from Grassham a few hours after the latter had dissected the bird.

"In the 'Norwich Nat. 'Trans.,' an enumeration was given of female Redstarts (Ruticilla phoenicurus) assuming male plumage $(l . c$. $)$ to which the following may be added: a hen $R$. phoenicurus assuming male plumage, and very like Mr. Millais' described in the 'Norwich Nat. Trans.' iv., p. 182, was caught by Mr. W. E. Clarke sitting upon her eggs, at Wike, near Leeds, in June, 1886; at the same time Mr. Clarke saw the cock close by, which appeared to be in the ordinary male plumage. The late Mr. Henry Doubleday's collection contained a hen Redstart ( $R$. phoenicurus) in male plumage, which had the ovaries 'quite perfect and full of eggs' ( $c f$. B. of Norf., i, p. 370, note), probably one of those alluded to by Yarrell (Brit. B. 1st ed. i, p. 240) in the remarks made by him on the plumage of this species. I have some recollection of this Redstart at the dispersal of Mr. Doubleday's collection, but do not know who was the purchaser of it. There can be no doubt that more would soon turn up if looked for; and now that attention has been drawn to the subject, and the practice of dissection is getting more general among bird stuffers, it is certain to be the case, not only in Ruticilla, but in other genera besides. Why it should happen in Ruticilla phoenicurus of tener than in other Passerine birds is hard to explain, but such is evidently the case."

"The same is recorded to have happened five or six times with the female Red-backed Shrike (Lanius colluria); see 'the Field,' June 17, 1871, and April 25, 1885; Mag. N. H., iv, p. 344; 'B. of Suffolk,' p. 45; 'Ibis,' 1863, p. 292; but the number of hen Redstarts which have donned masculine attire is greater.

"The following is a list of the species in which one or more instances of females assuming male plumage are ascertained to have occurred:

Falco aesalon, fide Scully. (Cf. Sharpe, 'Cat. Birds Brit. Mus.,' i, p. 407).

Tinnunculus alaudarius, fide Sharpe; col. fig. P. Z. S., 1874, p. 580.

Lanius collurio, fide Hoy.

Lanius vittatus, fide Blyth.

Ruticilla phœnicurus, fide Millais, Clarke and others. 
Fringilla colebs, fide Clarke.

Linota cannabina, fide Blyth.

Linota rufescens, fide Blyth.

Nectarinia asiatica, fide Blyth.

Gallus (domestic fowl), fide Yarrell and others; col. fig. "B. of Sherwood," p. 183.

Pavo (peahen), fide Latham; fig. "Synopsis," ii, pl. 60.

Meleagris (Turkey), fide Bechstein.

Phasianus colchicus, fide Edwards and others. Of common occurrence in a semidomesticated state.

Thaumalea picta, fide Edwards.

Euplocamus nycthemerus, fide Yarrell.

Pucrasia nipalensis, fide Blyth.

Tetrao tetrix, fide Bond; col. fig. Dresser, "B. of Eur.," vi, 205.

Tetrao urogallus, fide Nilsson; col. fig. "Unser Auer-, Rackel- und Birkwild und seine Abarten," by A. B. Meyer.

Otis tarda, fide Tiedmann.

Anas (domestic duck), fide Rowley; col. fig. "Orn. Misc.," i, p. 118.

Anas boschas, fide Hancock; fig. col. "Scandinavisk Fauna," pl. 163.

Fuligula marila, fide Blyth; sec also P. Z. S., 1885, p. 246.

Mergus serrator, fide Gurney.

Mareca penelope, fide Cecil Smith.

"Perhaps the Kestrel (Tinnunculus alaudarius) ought not to be included in this catalogue, for so many have been seen with the lower part of the back blue or bluish, as to leave little doubt that the female generally becomes so if she lives long enough.

"It is said that the females in Oriolus generally become as bright as males in time ('Ibis,' 1864, p. 412; 'Field,' June 24th and July 8th, 1871)."

"P. S.-Mr. W. Tegetmeier tells me he has known a barnyard cock moult into hen's plumage, which is the converse of the instances narrated in this paper, and rather resembles the annual change which takes place in Anas boschas and others of that tribe."

\section{In a later notice Gurney makes the following statement:}

"The bearded tit (Panurus biarmicus) may be added to the list of female birds which are known to occasionally assume male plumage. In the summer of 1882 a bearded tit, two years old, in Mr. J. G. Keulemans' aviary, hatched five eggs and moulted, during which operation she suffered much from cold and stiffness, and when she recovered her plumage it was partly that of the male (cf. 'The Field,' Sept. 14, 1872)."

Brandt, who has reviewed the literature very thoroughly, cites the following cases:

"Galeinacei: Gallus bankiva domest., Phasianus pictus, torquatus, colchicus, mongolicus and nycthemerus, Pavo cristatus domest., Meleagris gallopave domest., Perdix einerea, Tetrao urogallus, tetrix und bonasia.

"Passeres: Fringilla coelebs, Pyrrhula vulgaris, coccinea, Loxia chloris, Turdus merula, Ruticilla phoenicurus, ochrura, chrysogastra, Cyanecula Wolfii, Sturnus vulgaris, Ampelis cotinga.

"Scansores: Cuculus canorus, Edolius glandarius.

"Grallatores: Machetes pugnax.

"Natatores: Anas boschas domest.

"Es ware denkbar, dass die Hahnenfedrigkeit, wemn auch in verkapptem Grade, allen Vögeln, selbst denjenigen zukomme, deren Gefieder uns geschlechtlich uniform zu sein scheint. Wie dem auch sei, einzelne Genera und Species scheinen mehr, andere weniger zur Arrhenoidie prädisponirt. So 
bemerkt J. Geoffroy St. Hilaire (p. 511), dass Fasanen häufiger selbst als die Hühner hahnenfedrig werden, während für den Pfau, den man doch stets eines natürlichen 'Todes sterben lässt, ihm nur ein einziger Fall (der von Hunter) bekannt geworden. Während Lorenz (vide Tichomirow) auf dem Moskauer Markt häufiger hahnenfedrige Weibchen von Phasianus colchicus und mongolicus aufgefunden, ist ihm dieses fur Ph. chrysomelas bisher kein einziges Mal gelungen, obgleich die Zahl der jährlich in Moskau feilgebotenen Exemplare dieser Art sich auf 8000 Stück belaufen möchte."

The preceding cases relate to exceptional changes in the plumage as observed in nature, or in birds kept under domestication. We may next examine the cases where the ovary or the testis has been removed.

The earlier observations of Berthold, Wagner, Hanau, Samuel, Sellheim, Pirsche, Foges, Shattock, and Seligman are sufficiently covered by later work quoted below. Sellheim's work, however, is especially to be noted, since he gives some measurements covering the weight of the brain, heart, and body of the cock and capon, as well as observations on the skull and skeleton. The weight of the brain is slightly less in the capon, but the body-weight is greater. He questions whether the ovary has ever been successfully removed, and he shows that the operation of resecting the oviduct does not, as was supposed, lead to the degeneration of the ovary. On the contrary, he found that after the effects of the operation had been removed the ovary began again its functions.

From Goodale's careful summing up of the effects of castration only the following points need be recalled: The feathers are little changed; some of them, the hackles especially, become longer. The lowermost tier of wing coverts are elongated as compared with those of the cock. The spurs are practically the same in the capon and cock. The capon is disinclined to give voice, but at times he crows. The molting is not affected. The size of the capon is larger. He pays little attention to the hens. He is not pugnacious, and if attacked will not often fight. As a rule he does not pursue the hens, but if a hen squats down as the capon approaches he will mount and go through the characteristic mating reaction. The comb is extremely small, much smaller than that of the female of the same race; it is infantile rather than feminine.

Comparing these results with those that I have observed in the castrated Sebright, we find that aside from the assumption of the full plumage of the cock-feathered bird the Sebright shows all of the characteristic features of the capon. The spurs develop, perhaps even more fully'than in the normal Sebright cock. He seldom crows, and then weakly. The birds appear large, but the excessive development of the feathers produces the effect. I have not weighed them to show whether an actual increase in size takes place. Two of my birds are notably large for Sebrights, but the others are smaller. Both large and small cocks occur in the strain that I have used. My Sebright and other capons neglect the hens, but I have seen them tread the hens 
on occasion. They will fight each other, if two strangers meet, but the attacks are not violent or prolonged. A normal male beats them easily, and afterwards they run away from such birds. The combs and wattles are very small and pale. If a piece of the testis is left in, the comb is a fair index of its size. In the birds that changed back toward a Sebright the comb slowly enlarged. After the second operation it decreased again as the plumage once more changed to that of the eock.

Goodale's results with ovariotomized females are especially noteworthy, since here for the first time we have definite information as to the effects of the operation. By using a well-established breed, the brown Leghorn, in which the dimorphism of the sexes is very striking, the results are made all the more convincing. Goodale found that it was possible to completely remove the ovary of young birds, for at an early age the ovary is sufficiently compact to make its entire removal possible. Later the ovary becomes more diffuse, and complete removal is almost impossible. In a few successful cases, in which the ovary had been completely removed, the bird assumed the full plumage of the Leghorn cock, with red back, black breast, and long, pointed hackle and saddle feathers. Spurs developed in all the operated females, even when the ovary was not entirely removed. There can be little doubt that the ovary holds back the development of the spurs, but as some hens sometimes develop spurs, especially in certain breeds, it is not entirely certain that in these cases the loss of the ovary is the cause of the appearance. The comb (and wattles) developed to different degrees; in some birds it was as large as in the cocks, in others no larger than in the normal hen, but in all cases it was larger than in the capon. What to conclude is doubtful. Tentatively it may be suggested that the genetic complex that gives the female $(\mathrm{ZW})$ produces a comb as large as that shown by the female independently of the ovary, but beyond this point the ovary inhibits the further development of the comb, presumably by means of the same internal secretion that holds down the cock plumage in the hen. In the male, on the other hand, the genetic complex (ZZ) produces a comb much smaller than that of the female (no more than that of the capon), and the testes produce a substance that eauses this comb to grow to the size of that of the cock. Possibly, however, other internal secretions are involved.

The operated hens are quiet and nearly voiceless. None of Goodale's birds were heard to crow, yet this seems to be a well-known peculiarity of old hens that have become coek-feathered. The operated hens are not larger than the normal hens of the same breed. Their legs remain short, as in the normal hen; and in this respect and in size the ovariotomized bird is externally a female. The poullards "never visit the nests, never sing or cackle, show none of the normal female reactions, and few or none of the male." 
The influence of the ovary in suppressing the cock plumage has been convincingly shown in an experiment of Goodale's, in which, after removal of both testes from the young Leghorn cock, pieces of ovaries were inserted into the body-cavity. As dissection showed later, several of these implanted pieces grew onto the wall of the body-cavity. The birds developed the plumage of a hen, although some traces of the male plumage were at times present. The difference between the sexes is so great in Brown Leghorns that the hen-feathering of the feminized cockerels leaves no doubt that the presence of the ovary had produced the female coloration.

Geoffrey Smith and Mrs. Haig Thomas (1913) have examined a number of hybrid pheasants, some of which were sterile. They found that the ovary (and oviduct) was often small and degenerate. There was a more or less corresponding tendency for such female hybrids to show male feathering, at least in a part of the plumage. The degeneration of the sex element, however, does not take place until after the time of synapsis, so that the younger germ-cells may be normal. The later degeneration of these cells is not likely to influence the secondary sexual characters, but may be an index of changes in other parts of the ovary.

Geoffrey Smith had a breed of White Leghorns with cocks of two classes-those that assumed cock plumage at 6 months, and those that are like the hens for 8 months, after which they slowly assume the cock-feathering. The difference is hereditary and appears to segregate. Possibly this breed had one factor at least for hen-feathering that is more effective for young birds than for older ones.

Smith states that birds and crabs (see infra) appear to give opposite results, since removal of the ovary in the former leads to development of secondary male characters and removal of testes in the latter to secondary female characters. But he adds that he thinks the results are really the same, because in the crab it is not the suppression of the testis but the feminization of the male by the Sacculina that causes the change.

There are a number of observations on ducks. Several cases have been recorded where in old age the female assumed the male plumage (Darwin, Shattock, and Sellheim). Also a few cases in which the testes were removed. Those of Goodale are the most complete and striking. The male duck has two characteristic plumages, one called the nuptial also called the summer or breeding plumage that is assumed at the molt in the autumn, and the other the eclipse plumage, which is not identical with but much like that of the female. Here, then, we find a new situation, and one that invites comparison with the condition in Sebrights, in so far as the male becomes hen-feathered at certain seasons. 
Throughout the greater part of the year the Rouen drake has the nuptial plumage. The head is green and the breast is claret. 'Two median tail feathers are strongly curved; the next two are also often curved. These four are called the sex feathers. At the close of the breeding-season (July) both sexes molt. The male now has the same coat as the female, or nearly so. The green head becomes brown to buff; the sex feathers are straight. The change back again to the nuptial plumage beginsat the end of summer and is completed early in October. Thus in the race of Rouens the eclipse plumage lasts only a very short time. In the mallard it lasts longer. The eclipse plumage develops, therefore, only when the testes are active, or, as Goodale puts it, "the presence of the active testis is necessary for the drake to assume this plumage." Conversely, the nuptial plumage comes on in the late summer, when mating is over, and when the testes have shrunken and are not active, at least as far as the sex-cells are concerned. In some respects the situation is like that in the fowls, for in both the testes are not necessary for the development of the full plumage, but in other respects the situation is different, because at the time in the ducks when the testes are active the eclipse plumage develops. Are we to suppose that at the time of sexual activity a substance is produced analogous to that produced by the ovary of the female? This seems the most plausible assumption, for we know that if the testis is removed the eclipse plumage does not appear. Such a situation suggests a comparison with the Sebright, where it has been shown that the testis must actively produce some substance which, like that in the ovary, keeps down cock-feathering. It is plausible, even if it ean not be established, that the substance in the duck and the inhibitory substance in the male Sebright are the same as that produced in the female.

Goodale's results with females (ducks) are not so clear cut, because the ovariotomized females turned out to be of two sorts. One sort is almost identical with the male, the other is more intermediate. There are sufficient reasons for thinking, he says, that these differences are not due to defective operations. Goodale suggests a genetic difference in the females used, but this is apparently even to Goodale himself not a very satisfactory solution. For our present purpose the imnortant fact is that the ovariotomized female may assume the perfect male plumage. Evidently the ovary produces some substance which, as in the hen, suppresses the potential plumage of the male. Onesuch female known to have had all the ovary removed never assumed the summer (eclipse) plumage of the drake. On the other hand, another female developed first the nuptial plumage, but this was replaced by the summer coat "of the male of this variety." Again, in the summers of 1914 and 1915 the change to the eclipse plumage was followed in the autumn by a return to the nuptial plumage. 
How can we explain the apparent discrepancy of Goodale's results? In one case, the nuptial plumage was molted to nuptial plumage; in the other case an eclipse plumage appeared at the breeding-season. Goodale regards the latter case as a more perfect approach to the male than the former, but this view undoubtedly offers serious theoretical difficulties. It seems to me possible to suppose that in those cases where the summer plumage appeared there was in reality enough ovarian tissue (or related tissue) left after the operation to produce an effect at the normal season for such ovarian tissue to become most active. It might then suffice to eclipse the male plumage sufficiently to make it very similar to the eclipse of the normal male. At any rate, on this basis we have a consistent explanation of the entire complex of phenomena.

What bearing have these results relating to castration and transplantation on the theory of sexual selection? Granting, of course, that selection takes the materials as it finds them, there may still be restrictions imposed on the theory by the kind of material offered. For instance, the development of the plumage of the cock is independent of the condition of his testes. Hence, if the female selected the more vigorous male, she would not necessarily obtain one more ornate than his less vigorous rivals. If the taste of the hen has built up the plumage of the cock, it has been carried out then independently of the vigor resulting from the greater activity of the testis. In a word, the more vigorous male is not necessarily the most highly colored one. Darwin concedes that these two conditions, high color and vigor, must go together to insure success, or at least that the most vigorous and therefore the most highly colored male will have more offspring. Wallace's contention that the greater vigor of the male accounts for his greater development of plumage gets scant support from the facts of castration. One might rather contend that the female must be more vigorous, since she is obliged to suppress plumage that is allowed to run riot in the male.

Wallace's argument in favor of natural selection holding down the plumage in the female as a protection to her while nesting might appear to fit the facts better were it not that the quest for an explanation of the male's plumage is thereby abandoned. It should not be forgotten in this connection that the nest is generally only partly concealed, that bright color at rest need not be conspicuous, and that the male, exposed as he is through a considerable part of the year, still manages to maintain himself in about equal numbers with the female. Suppose, however, for the sake of argument, that natural selection has kept under the full possibilities of the female. The modus operandi would be competition between the least adorned females, suppression being brought about by the activity of the ovary; while the male is left therefore to exhibit the full possibilities of the genetic complex of 
his race without restraint. The facts in the case are that the plumage of the male is the direct result of his genetic composition; the female has the same genetic composition (the sex-linked characters are duplex), but the ovary produces a substance that holds them in restraint. Put in this way, there is nothing further to be explained, unless we insist on finding an explanation as to how the species came to have its genetic constitution. In other words, if we are not satisfied with the statement as to the actual situation, we must explain it by a utilitarian appeal to a relation between the plumage and the world outside of the individual or the species. To those who feel unsatisfied to leave the case as it stands on a physiological basis, there is another hypothetical means of escape. It may be assumed that the genetic factors that are instrumental in producing the secondary sexual characters have also other but unknown influences in the economy of the species, color and ornamentation being by-products of these factors whose utility in other directions accounts for their presence. Such a philosophy has perhaps one redeeming feature, since it suggests the possibility of searching for other influences-influences that only incidentally give the striking coloration and ornamentation of the males.

At first sight the absence of cock-feathering in the Sebright may seem to furnish the occasion for such a quest. It might appear that since only one or two genetic factor differences are responsible for the "nuptial" plumage of the male, that this plumage may have originated in one or two genetic changes. Such an argument is fallacious, however, for very many genetic factors may historically have been necessary to build up the nuptial plumage of the male. The breeding experiment shows no more than that one or two other factors have appeared that counteract the effect of all that the others are capable of producing; the experiment throws no light upon how many or how few these other factors may be. That the nuptial complex is still present in the Sebright is evident after castration. Castration shows only that the testes in the Sebright produce some material that keeps down the effects of all the other factors combined. This conclusion, it is true, somewhat simplifies the problem for those who appeal to natural selection as suppressing in the female the feathering of the cock, because it shows that this could have been accomplished by one or two Mendelian factors that appeared of such a kind that they caused the ovary to produce a substance antagonistic to the influences coming from the genetic complex of the species.

With this by way of provisional exposition, let us return to the question as to whether the Sebright-game cross throws any other light on the possibly useful character of the genetic factor or factors that produce cock-feathering. It is obvious that the evidence gives us no clue at all, for with the exception of the normal allelomorphs of the dominant factor for hen-feathering, all the other factors are still 
present in the Sebright. The normal allelomorph in question need not have had any relation to the other complex; in fact, it seems not to have any, because the castrated Sebright (with both normal allelomorphs replaced by genes for hen-feathering) still develops the characteristic cock-feathering.

The outcome in the duck with its double male plumage is still more puzzling when we attempt to analyze the situation in the light of the selection theory. At the height of the breeding-season, when his testes are enlarged and functioning actively, a substance is being produced that leads to the eclipse of the nuptial plumage. If the male were selected by his partner for his plumage, he would be chosen for a plumage that develops in the absence of the functioning testes. If the male is chosen because of his greater aggressiveness or "activity" or "vitality" due to the development of his testes, the result would be to select males that would probably develop a better eclipse plumage. The case is interesting because it gives an opportunity to distinguish between a plumage that develops under the influence of the sexual organs and one that does not; and the latter is paradoxically the nuptial plumage. It is true that the male might be selected for his nuptial suit, and, theoretically at least, female choice might still be made responsible for this plumage, but this merely shifts the problem, for it leaves "unexplained" the appearance historically of the effect of the activity of the testes in suppressing this plumage for a short time after maturity. No doubt an attempt might be made to show that natural selection comes in at this time of the year in giving a protective color to the male, but so long as any evidence is lacking as to the need of this protection the argument serves rather to further complicate an already difficult situation.

Goodale has written to me that there is an account, in the Agricultural Journal, Union of South Africa, Iv, 1912, of the effects of the removal of the ovary of the female ostrich. I have not been able to see the account, but according to my informant such female individuals assume the male secondary characters.

Of unusual interest in connection with the seasonal change of plumage in males of dimorphic species are Beebe's experiments with scarlet tanagers and bobolinks. In both species the males in their nuptial plumage are very different from the females. Full-plumaged males of both species, at the height of their "vocal and physical condition," were confined in small cages. The supply of light was gradually cut off and a slight increase of the amount of food was allowed them. The birds became less active in consequence and increased in weight. "The time for the fall molt came and passed and not a single feather was shed." The birds had skipped the autumn molt and remained in their nuptial plumage. The song soon died away; "the birds seldom uttered even a chirp." From time to time a bird was gradually brought into 
the light for a week or two and meal-worms were added to the diet. This invariably resulted in a full resumption of song.

"I found that a sudden alteration in temperature-either lower or higherwrought a radical change in the physical metabolism of the birds. They would stop feeding almost altogether, and one tanager lost weight rapidly. A few feathers on the neck fell out, and in the course of some two weeks this bird moulted almost every feather and eame strongly into his normal winter plumage of olive green. The metabolism set up by the change in temperature, in its intent and rapidity, seems comparable only to the growth of a deer's antlers.

"Early in the following spring individual tanagers and bobolinks were gradually brought under normal conditions and activities, with quick result; just as the wild birds in their winter haunts in South Ameriea were at that time shedding their winter garb and assuming the most brilliant hues of summer, so the birds under my observation also moulted into the colors appropriate to the season. The old scarlet and black feathers fell from the tanagers and were replaced by others of the same color; from buff, cream, and black, the bobolinks moulted into buff, cream, and black! There was no exception; the moult was from nuptial to nuptial, not from nuptial to winter plumage. The dull colors of the winter season had been skipped."

How are these results to be interpreted? Obviously the environment prevented the autumn molting; hence the birds necessarily retained their nuptial plumage. But is this the whole story? Did they not also remain sexually active with their testes producing sperm as in the mating season? In other words, if feathers had been plucked from them, would not the new feathers have been like those already present? Despite the author's statement that not a single feather was molted, is it not likely that occasionally a feather must have been accidentally lost. If even one had been lost and an eclipse feather had replaced it, the effect would not have escaped so keen an observer as Dr. Beebe. It seems to me not unlikely that an occasional feather may have been lost and replaced by a nuptial one. If so, then the results are most probably interpreted as due to the birds having remained sexually active. This condition suppressed the autumn molt, and at the same time would cause any single feather lost to be like those still present. In support of such a conclusion I can appeal to Beebe's statement that after a week in the light a full resumption of the song took place. It is unlikely that sexual maturity would be attained in so short a time unless the birds were already in the condition of sexual vigor. Perhaps one can appeal also to Beebe's other statement, viz, that after a sudden change in temperature, followed by a changed metabolism and loss of weight, the birds molted and assumed the eclipse (winter) plumage. Here I should interpret the facts cited possibly to mean that the males lost their sexual activity and in consequence developed the eclipse plumage.

Until further information is obtained judgment must be suspended. If, as Beebe's statements strongly suggest, the external conditions, 
acting directly on the "metabolism," cause the changes observed, then the experiments mean that environmental conditions affect directly the development of the nuptial and the eclipse plumage; but if, as I suggest here, the effects observed are due directly to the environmental action through its effects on the testes, then the results fall more nearly into line with those of Goodale on ducks, etc.

\section{Evidence from Amphibia.}

The thumbs of frogs enlarge at the breeding-season and shrink afterwards. The enlarged thumb is used by the male in clasping the female during copulation, and the rough papillæ that appear over its surface at this time may also help to anchor the male in his precarious position on the back of the female. Since the pads and their papillæ are used in copulation, they belong rather in the class of accessory organs of reproduction than in the class of secondary sexual characters. Smith and Schuster state for Rana fusca that the testes are at their smallest size in March and April after the breeding-season. From that time until August they steadily increase in size and reach their maximum size in September. From September to March they are inactive and full size, until the shedding of the sperm in March brings them soon afterward to their lowest point again. It is to be noted that the increase after March is associated with the increase in division rate of the spermatogonia. The ripening of the sperm is finished in October.

The thumb-pads with their pigmented papillæ are "cast off" immediately after the breeding-season, the thumb remaining smooth from May to September. The reduction of the pad is usually due to the reduction of the glands and the disappearance of the papillæ. Smith and Schuster state: "During the months when the most active growth of the testis is taking place the thumb-pads remain inactive and smooth." The implication, apparently, is that one ought to expect the growth in the thumb to take place when the germ-cells are most actively dividing, if its growth is connected with their activity; but there are no grounds for such expectations, because the influence of the gonad may have nothing to do with the division rate of the germ-cells, but rather with interstitial or other cells, and even here less with their division rate than with their period of greater secretive activity.

"In August and September the epidermal papillæ begin to be obvious, and from this time onwards until about February a continuous increase of the epidermal papillæ and pigmentation occurs. During the greater part of this time, when the thumb-pads are attaining their characteristic rough and pigmented appearance, the testes remain inactive and unchanged - a fact which has been too readily overlooked by writers on the correlation of the primary and secondary sexual characters."

Nussbaum (1909) and later Meisenheimer (1911) found that after castration the thumb-pads disappear. Smith confirms this report in all essential respects, although in certain details concerning the papillæ 
he does not agree with the two former observers. His results show that castration at the breeding-season is rapidly followed by the loss of the outer papillated layer of the thumb-pads, but castration at any other season does not have "any marked effect," the papillæ remaining for 5 months and more in the same condition as at the time of castration. The essential point here, however, is that the excessive and even special development at the breeding-season does not take place nor is again assumed (apparently), if castration has taken place at some other time of the year.

Smith and Schuster's attempts to transplant the testes into other males or females were unsuccessful, as the testes degenerate after a time. Auto-transplantation of the testes were more successful.

Removal of the ovary had no effect on the thumbs of the female, and even the injection of testes extracts into such females did not cause them to develop pads. Nussbaum and Meisenheimer had found that transplantation of pieces of the testes, and even injection of testes extract, into castrated frogs caused an enlargement of the thumb-pads. Smith shows that this conclusion rests on uncritical evidence. At any rate, his own more carefully planned experiments extending over the year show that the results obtained by Nussbaum and by Meisenheimer may be accounted for on other grounds than the effect of the injection or implantation.

The following statement by Smith is not without interest, since it bears directly on an important question as to how internal secretions may produce their effects.

"The deduction, therefore, which has been unduly based on Nussbaum's experiments, that the testis of the frog contains an internal secretion, which, on being circulated in the blood, calls for the development of the secondary sexual characters, either with or without the mediation of the nervous system, is without experimental foundation. . . . . The fact that the developinental cycle of the thumb depends for its normal course on the presence of normal living testicular tissue can be equally well explained on the theory that the testicular cells enter into a chain of metabolic processes in the body which do not pursue their normal course in the absence of the testicular cells. This disturbance of the normal metabolic processes of the body, resulting in the failure of the metabolic organs of the body to give rise to their normal products in normal quantities, may have the result of inhibiting the further development of the secondary sexual characters. The development of these latter characters may depend, therefore, not directly on the action of an internal secretion or hormone derived from the gonad, but on the elaboration of other products in other organs of the body in their due proportions. These substances may be tentatively called 'sexual formative substances,' but we have no reason for supposing that they are entirely devoted to sexual or reproductive purposes, and that they take no part in the ordinary metabolic processes of the body."

The arbitrary distinctions that Smith here sets up do not seem to me to contribute anything to the situation, and in fact in the end it amounts to practically the same thing whether the hormone acts 
directly on some specific part of the body or whether in doing so it acts on other parts as well. While it is more or less customary to limit the term "hormone" to substances that do produce specific effects in a particular organ, no one would, I suppose, deny that a substance was acting as a hormone if at the same time it acted on other parts of the body also, or even if its immediate action were on some part and its ultimate action on another part of the animal. Moreover, there is nothing in the evidence appealed to by Smith that supports one rather than the other contention. It is not apparent that the simpler idea of hormone action may not still apply. Failure to implant the testes in castrated male or female, and failure of injections to produce the results sought for, may mean no more than that the experimenter failed to fulfill some one of the conditions present in the normal frog at the breeding-season. Granting that the results recorded by Nussbaum and Meisenheimer are open to the serious objections, pointed out by Smith and Schuster, the facts recorded by all three writers indicate that the maximum development of the pad takes place when the testes are at their greatest development and that the pad suddenly decreases if at this time the testes are removed. It would seem to follow that since the swelling is connected with the presence of a certain condition of the testes, its enlargement is to be referred directly to the latter, and the case comes under the general category of "secondary sexual differences," depending on the gonad.

The secondary sexual characters of Triton cristatus can not, as can those of the frog, be supposed to be mechanically useful in mating, but seem to be comparable in every respect with the secondary sexual ornaments of higher animals. The work of Bresca has shown that their development is under the influence of the testes. The most important secondary sexual characters of the male are the dorsal comb and the white stripes of the tail. The comb extends along the dorsal surface of the body and of the tail (with a slight dip in the pelvic region). It is fully developed during the breeding-season, when it reaches a height of $1.5 \mathrm{~cm}$. In winter it is only $0.66 \mathrm{~mm}$. high, or even less. The white stripes also are fully developed in the breeding-season. They extend on each side from the cloaca to the end of the tail. In the female the white stripe is sometimes faintly seen. The angles of the tail and of the cloaca thickening are black-brown or black. The belly of the male is bright orange or "Ziegel rot"; that of the female sulphur-yellow or orange, but the difference is not constant. The upper surface of the head of the male is marbled, especially during the breeding-season almost disappearing during the rest of the year. Bresca found, when the testes were removed from sexually mature males, that in the course of a year all the important secondary sexual characters disappeared, including the comb, the white tail stripes, and the marbling of the upper surface. Removal of the ovaries did not affect the characters of 
the female. The black lower corner of the tail in the male is not changed by castration.

When the skin along the middle line of the back of the female is transplanted upon the back of a normal male (in place of his own comb) the transplanted tissue develops into a comb. In other words, under the influence of the testis, the dorsal mid-line tissues of the female change into those characteristic of the male. When pieces of skin of a male with the white tail stripes are grafted on the side of the tail of another male, the stripe remains, but when grafted similarly on a female the stripe slowly disappears. The result shows that its presence depends on the testis.

A remarkably clear case of hermaphroditism in amphibians was found by V. la Vallette St. George. He found an individual of Triton tcriatus that was outwardly a male with well-formed dorsal comb. In the interior were two large testes in normal position and just lateral to these on each side a large ovary. Sections showed ripe sperm in the testes and typical ova in the ovary. Sperm-ducts were present, but no oviducts. The presence of the testes will, of course, account for the development of the secondary sexual characters of the male.

Other cases amongst the Anura have been recorded by Loisel and by Marshall, Spengel, and Knappe. In the early stages of the gonad in frogs there appears to be an hermaphroditic stage in which egg mothercells and sperm mother-cells are both present, at least in those individuals that will later become males (Kusakowitsch).

The normal hermaphroditism of certain fish (Serranus) and its rare occurrence in other species (recorded by Shattuck and Seligmann) need not be recorded here. ${ }^{1}$

\section{Evidence from Crustaceans.}

In the Crustacea the secondary sexual characters are not marked, except in a few cases. In the amphipods, Holmes has shown direct contact plays the chief rôle in mating, and in the crayfish it has been shown by Dearborn, Andrews, and Pearse that sex recognition is largely tactile. Chidester also has shown this in crayfish. Even in crabs, and especially those living on land which have well-developed eyes and good vision, secondary sexual differences are as a rule slight and the mating instincts simple. On the other hand, the enormous chela of the male of the fiddler is supposed to be a secondary sexual difference (mainly because no other use for it has been found). Pearse suggests that the waving of this claw by the male is uscd as a sex signal, although he is disinclined to accept Alcock's view that it has become "conspicuous and beautiful in order to attract the female."

The most remarkable case known of a change in the secondary sexual characters of one sex into those of the other was discovered by

1 See the latter also for references to Lacertilia and Chelonia. 
Giard in 1886. As a result of infection by parasitic crustacea (e. $g$., Sacculina), the male crab develops the secondary sexual characters of the female. It has been generally supposed, following Giard, that this result is due to the destruction of the testes of the male by the roots of the parasite that invades the spaces between the organs of the host, and, in the case of the testis, ultimately brings about its partial or complete destruction. Not unnaturally the results here were supposed to be parallel to those of castration in vertebrates, and received in fact the name of "parasitic castration." More recently Geoffrey Smith has studied this phenomenon in the crab Inachus, infected by the parasite Sacculina, and has reached the conclusion that the change is not due to injury or to destruction of the testes, but to a change in the metabolism of the crab brought about by the parasite.

Taking Geoffrey Smith's case of Inachus-Sacculina as typical, the changes brought about are as follows: The parasites attach themselves to the young crabs before the external secondary sexual differences have appeared. In the females, the effect is to cause them to develop prematurely the distinctively female characters. In the male, on the other hand, the narrow abdomen of the male changes after a molt into the broad abdomen of the female, which also develops ovigerous appendages on its ventral surface like those of the female in every detail. The larger claw of the male changes into that of the female, which is different in form as well as in size. Some years ago I ventured to raise the question as to whether these effects on the male might not be interpreted as retention of the juvenile characters rather than development of the female characters in the male. This might appear more especially the case in the somewhat more juvenile shape of the anterior abdominal appendages and possibly also in the shape of the broader abdomen; but Smith has later shown that the results can not be interpreted as juvenile, for when the changed organs are examined in detail they are found to differ from the same organs in the juvenile condition, and to be identical with those of the adult female. I think, therefore, that we must accept this interpretation of Giard and of Smith as correct. But Smith goes further and believes that the effects may be carried so far that eggs develop in the old testes; in other words, that the testis changes to an ovary. It seems to me that the evidence to support this last point should be much stronger than that advanced by Smith before we can accept this interpretation, for we lack the essential control for this evidence. In only a single case were eggs found-in the testis of a male that had been infected, but from which the parasite had fallen off, and which was presumably recovering from the effects of its presence. Now, it is known that in the testes of some male animals a few eggs may occasionally be found where there is no suspicion that the animal has changed its sex. In some crustacea, in scorpions, and in insects, isolated instances of this kind have been found. Abnormal division 
of a spermatogonial cell, of such a kind that both sex chromosomes (in the case of insects at least) got into the same cell might be expected to cause such a cell to become, even in the male, an egg-cell rather than a sperm-cell. The degenerative changes of the testes in the hermit crab caused by the parasite might be imagined to favor such abnormal division with its consequences. More significant, however, is the fact that the parasite causes the absorption of the ovary when it infects a young female, so that even all its eggs disappear. In other words, the parasite is as injurious to the peculiarly female organ as it is to the testis. Why, then, one can not but ask, should an influence that causes such effects on the ovary first change a male into a female so long as it is present and then when the parasite has disappeared leave an influence behind of a kind that causes the ovary to develop-an organ which the parasite destroys when the parasite is present? Is it not more probable that only the secondary sexual organs were changed, without change in sex, the single case of eggs observed being caused in another way? This point can only be settled by direct experimentation either by removal of the testis, by injuring it, or by injection, grafting, or feeding experiments. The extent of the testis and its position make it impossible to remove it by an operation, as I have found after repeated attempts. It seemed easier to destroy it by radium. This I have tried to do, using very powerful tubes, treating the crab (fiddler crabs) for several hours. The crabs had had one claw removed-the enormously large one-and were kept until the next molt, that occurred from a week to six weeks later. In none of the cases was any change produced. The large claw of the male regenerated, of course, not full size after only one molt, but after several nearly full size and always with the peculiarities of the male crab. The abdomen and the appendages were not changed. Whether the significant cells of the testes, if there are such cells apart from the germ-cells, were destroyed, can not be told, for as yet the histological examination of the material has not been made. Until a successful operation has been done, I think we must hesitate to accept Smith's argument, although based as it is on a series of interesting observations. His speculation is as follows:

"The reason why Sacculina causes the assumption of the adult female state in Inachus is found in the facts: (1) that the roots of Sacculina elaborate a yolk-substance from the blood of Inachus of a similar nature to that which is elaborated in the ovaries of an adult Inachus; (2) that in order to elaborate this yolk-substance the roots take up from the blood of Inachus the female sexual formation substance, which is the necessary material for forming the yolk; (3) that the female sexual formative substance being absorbed by the sacculina roots is regenerated in excess; (4) that the presence of the female formative substance continually circulating in large quantities in the body-fluids of the infected crabs causes the production of adult female secondary sexual characters, and, when the parasite dies, of yolk-containing eggs."

In brief, the evidence consists in showing that in the parasite a yolksubstance appears, which Smith says comes from the blood of the crab 
that produces it under the influence of the parasite. Incidentally, as it were, this is said to be the same yolk-substance (but no sufficient evidence that it is the same is given) that the egg stores up inside itself, and it is assumed that it is a formative substance that causes the cell that gets it (or contains it or secretes it-details are wanting) to become an egg-cell. It is the excess of this substance produced by the male crab, while still a male, under the influence of the parasite, that affects the abdomen and its appendages in such a way that they assume the female condition. There are too many assumptions in the argument, some of which are scarcely of a kind that our knowledge of development, incomplete as it is, can allow us to accept without more direct evidence in their support, to make this view very plausible. Until better evidence is forthcoming, I fail to be convinced by Smith's interpretation of his facts.

Into Smith's and Robson's interesting observations on the blood of crabs, described in Smith's later paper (part 7, 1911), it is not necessary to enter here, since the evidence taken as a whole offers little further in support of his view than had been already assumed. The argument on page 263 should not, however, pass unchallenged. Smith says:

"It is clear that the old and familiar idea of an internal secretion produced by the gonad being the stimulus for the development of the secondary sexual character could not be applied here, since at the time that the alterations in the secondary sexual characters take place no ovary is present to give rise to the required stimulus. It is suggested, therefore, that in some way the stimulus must reside in the roots of the Sacculina," etc.

The argument seems to imply that, since the secondary sexual characters of the female can not be produced by an ovary in the infected male, therefore the Sacculina must take the place of the ovary. But why make such a supposition, for if the testes simply keep down the development of the female characters, as Giard supposes, there is no need either for an ovary or for a Sacculina to develop them. One might as well argue that since the cock does not develop the secondary sexual characters of the hen that an ovary is essential for their developmentwhich is true, but not in the sense implied.

Stamati (1888) states that he attempted to remove the testes of adult crayfish and apparently succeeded, but since no effects are expected until after a molt occurs (that may not take place for two years or more), no results were obtained. Injections of the gonads with an acid failed, since the animals died.

\section{E. EVIdence From Insects.}

In 1899 Oudemans succeeded in finding a method of removing the testes and ovaries from caterpillars, using a dimorphic species, Ocneria dispar, the gipsy moth. The results were negative; none of the secondary sexual characters of the male or female moths or the accessory organs of copulation were in the least affected by the operation. The castrated male copulated as readily with the female as did the normal 
male, while the spayed females also behaved as normal individuals of that sex behave. Kellogg, in 1904, repeated the same operation in the silkworm moth on a small scale with the same results. Kopec and Meisenheimer, in 1909, repeated in a more detailed way Oudemans's work. A further important addition was made by Kopec and by Meisenheimer. They transplanted ovaries into a castrated male and testes into a spayed female. Neither gonad produced any effect on the characters of the other sex. It is interesting to note that the testes underwent their normal development in the body of a spayed female, and even in one with the ovaries present, and that the ovary also underwent normal development in the body of the male. In other words, there is no intolerance of the tissue of one sex to the gonad of the other. This result is all the more unexpected, because other observations have shown that the color of the blood, and its chemical properties, is quite different in the male and female moths of certain species.

In the case of moths, therefore, if these cases be regarded as typical, the situation from the point of view of sexual selection is much simpler than in birds in the sense that the secondary sexual characters are directly the product of the genetic constituents of all the cells, and not influenced indirectly by the secretions from the testes or the ovaries. Sexual selection, therefore, if it is an agent in the evolution of the differences between males and females, has acted on the genetic complex to produce these effects on either sex without the result being involved in the condition of the ovary or the testes.

Regen castrated crickets, Gryllus campestris, in the larval stages and found no effects on the adult structures. The castrated males chirped like normal males and mated with the females. Spayed females were like normal females; they bored holes in the ground, but laid no eggs in them, of course, as the ovary had been completely removed.

The only genetic evidence in the group of insects, outside of the vinegar fly, relating to the secondary sexual inheritance of the secondary sexual characters is the following important experiments made by Foot and Strobell:

The male of one of the bugs, Euchistus tariolarius, has a black spot on the end of the abdomen-a spot that is not present in the female. Foot and Strobell crossed a female of this species to another bug, $E$. servus, that lacks the spot in both sexes. The daughters had no spot, the sons a faint spot less developed than in variolarius. These inbred gave (in $\mathrm{F}_{2}$ ) 249 females without a spot, 107 males with a spot, and 84 males without a spot. The results are explieable on the view that a single dominant Mendelian factor, not-sex-linked, causes the spot in the males, but the presence of the gene in the fomale produces no effect. The effect, therefore, is sex-linited, $i$. $c_{\text {. }}$, its expression is determined by the rest of the complex male or female.

The very important breeding experiments carried out by Goldschmidt on varieties of the gipsy moth should be referred to in this 
connection, but as I have recently reviewed these results in the paper on gynandromorphs written in collaboration with C. B. Bridges, ${ }^{1}$ I need only refer to that account here.

[Note added April 21, 1919.]

Shortly after the preceding paper was finished a theses by A. Pézard on the secondary sexual characters of birds reached me. In it the author gives an account of a number of experiments that he has made with poultry and with pheasants. His description of the changes that take place after castration are more exact and more detailed than any other so far recorded; but in general the results obtained by Pézard, through castration, are the same as those that had been obtained by others. Castration of 4 male silver pheasants are reported. No change in the plumage results, although the changes that take place in the comb and wattles are the same in kind as those observed in fowls. The sexual instincts and peculiarities of the voice and their belligerency are also lost. Similarly 4 golden pheasants that were operated on gave the same results.

Three pheasants with mixed plumage (Phasianus colchicus) were examined. Their testes proved, on histological examination, to be imperfectly developed. It is not evident what relation existed between the facts and the mixed plumage. The suggestions made by Pézard seem inadequate to cover the cases.

Testicular tissue transplanted into castrated cocks whose comb, wattles, etc., had undergone retrogressive changes brought about a return to the normal conditions after an interval during which the implanted nodules had begun to regenerate.

Testicular extract from the cryptorchid testes of swine was injected into castrated cocks. In one case this resulted in a rapid growth in size of the comb, which, after 2 months, had reached its full size. Cessation of the injections led immediately to a cessation of growth. Before injection the bird exhibited the pacifistic characteristics of the capon, but the injections brought out little by little the aggressive behavior of the normal male. The voice reappeared and "nous assistons á une véritable crise de puberte."

A histological study of the testes of the fowl and of pheasants showed that much connective tissue is characteristic of young birds. In the adult cock, and during the mating season of the pheasant, the connective tissue becomes largely crowded out by the enlargement of the tubules. Pézard concludes that the "interstitial " cells in birds have nothing to do with the secondary sexual characters, but that these come rather under the influence of the germinal cycle of cells of the testes. The submergence of the connective-tissue cells of pheasants during the breeding-season and their reappearance during the rest of the year might appear to have some relation to the facts that I have recently described in Sebrights, but as the nuptial plumage of the male remains the same throughout the year we can not ascribe any direct influence to this tissue. Nevertheless, the different tissues of the testes in birds that show seasonal dimorphism of plumage should be carefully examined.

Pézard made a few observations on hens whose ovary had been removed. His results are in accord with those of Goodale, except that he thinks that the ovary has no influence on the erectile organs (comb, etc.) which acquire in the spayed bird the same length as that of the normal female.

Two hens showing male characteristics and a pheasant similarly affected are described. In all three cases an examination of the ovary was found to be undeveloped or abnormal.

1 Carnegie Inst. Wash. Pub. No. 278, 1918. 


\section{SUMMARY AND CONCLUSIONS.}

1. The two principal results obtained were: $(a)$ that eastration of hen-feathered Sebright males causes them to develop the full plumage characteristic of the cock-bird; $(b)$ that complete hen-feathering is due to two dominant Mendelian genes.

2. A striking change takes place when the Sebright male is castrated (plate 1, figs. 3, 4; plate 3, fig. 1). The new feathers on the upper surface of the head, neck, back, wings, rump, and tail-coverts assume a different color and distribution of their pigment; they take on a new shape, and in those regions where in the cock the barbules are absent from a part of the margin of the feather, the same absence oceurs in the castrated birds. Such feathers are present on the neek, back, wingbow, and rump. The transition is shown in the figures in plate 6 , where for comparison one of the old and one of the new feathers lie side by side. The tail-coverts in the hen-feathered bird are short, and like those in the hen do not cover the true tail. After castration they become excessively long-longer, in fact, than in many cocks-and cover the true tail feathers. The tail feathers themselves, moreover, become inereased in length, as do the posterior row of feathers of the wing-coverts. On the breast and sides the change is less marked. The castrated Sebright loses his erect earriage, but how far this is due to the changes in his plumage and how far is real (as a result of a new balance due possibly to the lengthening tail and its coverts) I can not decide.

3 . While castration causes the hen-feathered male to make additions in color, length, and size of many feathers, it causes at the same time the other retrogressive changes characteristic of the capon (a castrated cock-feathered bird); the comb and wattles shrink and become pale, the birds almost cease crowing, and become timid. They do not make much effort to mate with the hens, but when they do they show the usual copulatory reactions.

4. If feathers are removed at the time of castration, the new feathers show the full effect of the removal of the testes, although they must have begun to develop immediately afterward. It is suggested that by means of this delicate test the time relations of the internal secretion can be profitably studied.

5. Feathers that may have started their development at the time of the operation show the old influence at the tip of the feathers (plate 10) and the new one in the rest of the feather. The change is abrupt, although the transition is perfect.

6. Incomplete castration of the hen-feathered male leads to smaller changes in the same direction than those following complete castration.

Where such small pieces of the testis were left that complete cockfeathering followed, the bird slowly changed back to hen-feathering 
as the testes began to regenerate. When the regenerated pieces were removed the bird became cock-feathered again.

7. One Sebright male whose testes appear to have been completely removed did not change the character of the plumage. No testes were found on autopsy. It is suggested that some other endocrine organs have taken over the function of the testes, but as yet none such can be indicated.

8. In one case an old hen-feathered $\left(\mathrm{F}_{1}\right)$ male began to change over to cock-feathering. It was found that his testes had dwindled (probably through disease) to very small size (10 by $5 \mathrm{~mm}$.).

9. The $\mathrm{F}_{1}$ male of the cross between the Sebright and game is also hen-feathered (plate 2, fig. 1). After castration he becomes cockfeathered (plate 2, fig. 4) and shows thereby the genetic type of the heterozygous cock-feathered class in which his hen belongs. The change in this male is even more strking than that in the Sebright. The change in the individual feathers is shown in plate 7, figs. 1 and $1 a$.

10. Three types of $F_{2}$ hen-feathered castrated males are shown in plate 2, figure 3 , and plate 3 , figure 3 and figure 4 . The first was a dark bird that changed to a lighter red above. The third a gray bird that became bright red; the second was a light yellow that became deep yellow, etc. The class of hens to which such males belong, as cock-feathered birds, can thus be found out by castration. In this way the $\mathrm{F}_{2}$, and back-cross, hen-feathered cocks can be classified with the corresponding $\mathrm{F}_{2}$ cock-feathered males.

11. In the $F_{2}$ generation, made up of birds from the direct and reciprocal crosses taken together, there were 29 hen-feathered and 26 cock-feathered males. In the back-cross $\left(F_{1}\right.$ hen by game male) the classes were 2 and 7 . The results seem in better accord with the assumption that two factors are present in the Sebright that stand for hen-feathering; that either alone will give hen-feathered birds (intermediate type?), but that both together give the extreme type of hen-feathering seen in the Sebright.

12. The difference in color in the two races (Sebright and Black Breasted Game bantams) is very great. The former have almost uniformly laced feathers, while the latter has the varied plumage of the jungle-fowl. The game is strongly dimorphic in color and colorpattern; the Sebright has the same type of coloration and pattern both in the male and female, but this is deceptive, as castration shows, because the castrated male is as strikingly different from the normal Sebright female as is the cock of other birds from the hen. The resemblance of male and female in this race is due to the suppression of the true male plumage by something produced in the testes. Therefore the heredity of dimorphism resolves itself here into the problem of the heredity of hen-feathering. That the female Sebright has the same genetic factors as the male is shown by the fact that she trans- 
mits hen-feathering in the same way as does the male, and also by the fact, as Darwin pointed out, that an old female Sebright whose ovaries had degenerated developed not the hen-feathered plumage of her own cock, but cock-feathered plumage like that of most male poultry.

13. The color of the $F_{1}$ birds is shown in plate 2, figs. 1 and 2. In general, the feathers are stippled, black and light yellow being the two most conspicuous ingredients. Since hen-feathering dominates, the dimorphism is absent, or at least is so slight as to not attract attention - little more, in fact, than in the Sebright race. The carriage of the male is like that of the Sebright male. The $F_{1}$ male and female are alike in the direct cross and the reciprocal, or at least no conspicuous difference is found between the two classes of hens, indicating that no important sex-linked factors are involved in the cross.

14. The $\mathrm{F}_{2}$ birds show a great variety of color and pattern, but those obtained can be approximately grouped into 16 classes. The classes are, however, admittedly not uniform, indicating minor factors not here reckoned with. The classification of the hens is easiest; the $\mathrm{F}_{2}$ hen-feathered males can then in many cases be referred to the proper classes; the $\mathrm{F}_{2}$ cock-feathered males can not be accurately classified with their corresponding hens, except in the case of those that resemble the two $\mathrm{P}_{1}$ males, the $\mathrm{F}_{1}$ male, and those that castration experiments of the hen-feathered males have shown to belong to certain hen types.

15. Despite the admitted difficulties of classification, it is suggested that three factor-pairs of differences will cover the main color classes seen in the $\mathrm{F}_{2}$ and in the back-cross. One or two of these seem to be incompletely dominant, since the $\mathrm{F}_{1}$ birds are not like either parent in any single character, nor are they like the wild type in so far as this is represented by the game.

16. A histological examination of the testis of the male Sebright by Boring and Morgan has shown that it contains cells like those present in the ovary of all breeds of poultry. These cells are ealled luteal cells by Pearl and Boring, from their resemblance to the cells of that name found in the corpora lutea of mammals. In the mammals similar cells are supposed to produce internal secretions that act as hormones. Their function in the female bird is unknown, but the fact that after the removal of the ovary the female develops the secondary sexual plumage of the male suggests that some secretion from these cells performs this function. Their oecurrence in the male Sebright and their complete absence, or paucity, in the males of other races supports strongly the view that these cells are concerned with the suppression of the secondary sexual plumage.

17. While in mammals the interstitial cells have been supposed to produce an internal secretion that causes the development of some of the secondary sexual characters of the male, and the fuller elaboration of others, in birds no such connection exists, if we except the casa 
of the Sebright. Castration of ordinary males does not affect deleteriously the secondary sexual plumage (although it does the comb, behavior, etc.), in fact may even enhance their effects. But, while in the mammal a secretion is necessary for the full development of the secondary sexual characters, in the Sebright a secretion inhibits certain of them. What element in the ordinary bird and in the Sebright causes the full development of the comb, wattles, sexual behavior, etc., is not known. Possibly it is the sexual elements themselves, but possibly it is a secondary influence of the luteal cells producing a contrary effect on these parts from its effects on the feathers; but possibly more than one kind of secretory cell is present in the testis of the cock.

18. The causes of the development of the secondary sexual characters are seen to be of such diverse physiological kinds that one may well hesitate to apply the same explanation as to their evolution. In fact, it is pointed out that several of the theories that have been suggested run counter to the conditions that bring about the development of the secondary sexual characters.

19. An attempt is made to give a critical review of Darwin's theory of sexual selection in the light of the modern genetic and operative results on the secondary sexual characters of the vertebrates. It is pointed out that far from extending the general theory in its applications, the modern work has shown in the first place that the underlying conditions that call forth the development of the secondary sexual differences are so diverse in the different groups of animals that it is a priori very unlikely that this evolution can have been directed by the same external agent, such as the choice of the female, for such an assumption carries with it in several cases other implications concerning the causes of the suppression of these same characters in the female herself, etc. In the second place, it is pointed out that the problem of the excessive development of certain characters in the male whose genes are present in both sexes no longer oppresses us as it did Darwin, for it has been shown both by the genetic and by the operative work that a single factorial difference may be at the root of exceedingly great differences in the individual. Such results, while they admittedly do not in most cases tell us that the differences involved have arisen at a single progressive step, show us nevertheless that such differences may depend on very simple initial differences, and if so, the entire problem becomes enormously simplified. To Darwin the excessive development of color and ornamentation appeared due to a long, slow process of evolution laboriously brought about by the female through selection of those males a little more ornamented than their fellows. To-day we have found out that in many cases the genetic composition of a male with such ornamentation and of a female without it may be almost identical, except that the genes in one chromosome are duplex in one sex and simplex in the other. Owing to this initial difference, the 
female in birds produces an internal secretion that suppresses in her the ornamentation shown by the male, and in the mammal an internal secretion produced by the testes causes the full development in the male of the secondary sexual characters. If, as seems probable, these secretions are some particular kind of substance, the condition that led to their appearance historically need not have been very complex; and if not, the problem appears simplified. It still remains to give some reasonable explanation as to why such substances should continue to be produced if their products-the secondary sexual characterspossess no "beauty" for the female. Here more work is necessary, but the modern genetic point of view may possibly give an important clue. We are coming to realize more fully that the hereditary genes generally have more than a single effect on the characters of the animal. The secondary sexual characters may, then, be only by-products of genes whose important function lies in some other direction. If, for example, the secretion produced by the cells of the male have an important influence on his output of energy, or strength, or activity, their secondary influence over certain parts of the body would not call for any further explanation on the modern view of natural selection. If the secretions of the ovary of the female bird have some direct relation to her physiological processes that are important in the development of the oviduct, for instance, it would be a matter of no importance from an evolutionary point of view if that same secretion suppresses in her the development of the high color shown by the male. 


\section{BIBLIOGRAPHY.}

AlCOCK, A., 1892. On the habits of Galasimus annulipes. An. Mag. Nat. Hist., VI.

ANCEL, P., ET Bouin, 1906. Sur l'effet des injections d'extrait de glande interstitielle du testicule sur la croissance. Compt. Rend. Acad. Sc. Paris, CXLII.

Arkell, T. R., 1912. Some data on the inheritance of horns in sheep. N. H. Agr. Exp.

Sta. Bull, 160.
1912. The nature of the inheritance in sheep. Science, n. s., XXXV.

—_ , and C. B. Davenport, 1912. Horns in sheep as a typical sex-limited character. Science, n. s., XXXV.

Bateson, W., and E. R. Saunders, 1902. Experiments with poultry. Reports Evol.

Committee, I, Part II.
- - E. R. Saunders, and R. C. Punnetr, 1905. Experimental studies in the physiology of heredity. Reports Evol. Committee, II.

- - 1906. Poultry. Reports Evol. Committee, III. Committee, IV.

- - and R. C. Punnet, 1911. The inheritance of the peculiar pigmentation of the silky fowl. Jour. of Genetics, III.

_- 1913. Mendel's principles of heredity. Cambridgc.

BAUR, E., 1914. Einführrung in die experimentelle Vererbungslehre, Berlin.

Beebe, C. W., 1908. Preliminary report on an investigation of the seasonal changes of color in birds. Amer. Nat., XLII.

Bergendal, D., 1888. Üher abnorme Formen der ersten abdominalen Anhänge bei einigen Krebsweibschen. Bihang till K. Svenska Vet.-Akad. Handlingar, XIV.

Bertkat, P., 1891. Beschreibung eines Arthropodenzwitters. Arch. f. Nat. ges., I.VII.

BoND, C. J., 1913. Some points of genetic interest in regencration of the testis after experimental orchectomy in birds. Jour. of Gen., III.

1914. On a case of unilateral development of secondary male characters in a pheasant, with remarks on the influence of hormones in the production of secondary sexual characters. Jour. of Gen., III.

Boring, Alice M., 1912. The interstitial cells and the supposed internal secretion of the chicken testis. Biol. Bull., XXIII.

- - and Raymond Pearl, 1917. Sex studies, IX. Interstitial cells in the reproductive organs of the chicken. Anat. Record, XIII.

— - 1918. Sex studies, X. Hermaphrodite birds. Jour. Exp. Zool., XXV.

—_, and T. H. Morgan, 1918. Lutear cells and hen-feathering. Jour. of General Physiology, I.

Bourne, A. G., 1884. On certain abnormalities of the common frog. Quart. Jour. Micro. Science, XXIV.

BRANDT, A., 1889. Anatomisches und Allgemeines über die sogenannte Hahnenfedrigkeit und über anderweitige Geschlechtsanomalicn bei Vögeln. Zeits. f. wiss. Zool., XLVIII.

Bresca, G., 1910. Experimentelle Üntersuchungen uber die sekundären Sexualcharaktere der Tritonen. Arch. Entw.-mech., XXIX.

CAstle, W. E., 1912. Are horns in sheep a sex-limited character? Science, n. s., XXXV.

Chidester, F. E., 1911. The mating habits of four species of the Brachyura. Biol. Bull., XXI.

Cholodowsky, N., 1908. Über den Hermaphroditismus bei Chermes-Arten. Zool. Anz., XXV. 
Cilleuls des, J., 1912. A propos du determinisme des caractères sexual secondaires chez les oiseaux. Compt. Rend. Soc. Hiol., LXX'1II.

Cunningham, J. T., 1908. The heredity of secondary sexual characters in relation to hormones, a theory of the heredity of somatogenic characters. Arch. Ent. Med., XXVI.

Darwin, Chartes, 1868. Animals and plants under domestication.

Davenport, C. B., 1906. Inheritance in poultry. Carnegie Inst. Wash. Pub. No. 52, 1908.

—— 1909. Inheritance of characteristics in domestic fowl. Cirnegie Inst. Wissh. Pub. No. 121, 1909.

- 1911. Another ease of sex-limited heredity in poultry. Proc. Soc. Exyp. Biol., Med., IX.

- - 1912. Sex-limited inheritance in poultry. Jour. Exp. Zool., XIII. 1912.

Dittrich, V. R., 1888. Über Andrena praecox $\&$ und Astacus fluviatilis \& Init teilweise männlichen Kennzeichen. Zeit. f. Ent., XIII.

Durham, F. M., and D. C. E. Marryat., 1908. Note on the inheritanec of sex in canaries. Reports Evol. Committee, IV.

Foges, Arthur, 1903. Zur Lehre von den sceundïren Geschlechtscharakteren. Arch.f. Plhys., 93.

Fowler, C. H., 1894. Notes on some specimens of antlers of the fallow deer, showing continuous variation and the effects of total or partial castration. I'roc. Zool. Soe. London.

Gedpes, A. C., 1910. Abnormal bone growth in the absence of functioning testicles. Proc. Roy. Soc. of Edinburgh, XXXI.

Giard, A., 1904. Comme la castration agit-elle sur les earactères sexuels secondaires? Compt. Rend. Soc. Biol., LVI.

Gissler, C. F., 1881. Description of a hermaphroditic phyllopod crustacean (Eubranchipus). Am. Nat., XV.

Goodale, H. D., 1909. Sex and its relation to the barring factor in poultry. Science, XXIX.

- 1910. Some results of castration in ducks. Biol. Bull., XX.

_- 1910. Breeding experiments with poultry. Proc. Soc. Exp. Biol. Mel., VII.

- 1911. Studies in hybrid ducks. Journ. Exp. Zool., XX.

— 1 1913. Castration in relation to the secondary sexual characters of Brown Leghorns. Am. Nat., XLVII.

— — - 1916. A feminized cockerel. Journ. Exp. Zool., XX.

-_ - 1916. Gonodectomy. Carnegie Inst. Wash. Pub. No. 243.

- 1917. Crossing-over in the sex chromosome of the male fowl. Scienee, XIJI.

Gurney, J. H., 1888. On the oceasional assumption of the male plumage by female birds. Ibis, VI.

Guyer, M. F., 1909. The spermatogenesis of the domestic guinea (Numida meleagris dom.) Anat. Anz., XXXIV.

_- 1909. The spermatogenesis of the domestic chicken (Gallus gallus dom.). Anat. Anz., XXXIV.

-1909 . On the sex of hybrid birds. Biol. Bull., XVI.

_- 1909. La livré e du plumage ehez les hybrids de pinta de et de poule. Bull. du Museum. d'hist. Nat. No. 1.

- - 1910. Accessory chromosome in man. Biol. Bull., XIX.

Guturie, C. C., 1911. On evidence of some influence in offspring from engrafted ovarian tissue. Science, XXXIII.

HadeeY, P. B., 1913. Studies on inheritance in poultry. 1. The constitut ion of the White Leghorn breed. Bull. Agr. Exp. Station of the Rhode lsland state College, No. 155.

—— 1914. 11. The factor for the black pigmentation in the White Leghen brevel. Bull. Agr. Exp. Station of the Rhode Island State Cullege, No. Kil.

Halban, J., 1903. Die Entstehung der Geschlechtseharaktere. Areh. f. Giynikologie, LAXX. 
HanaU, A., 1897. Versuche über den Einfluss der Gesehlechtsdrüsen und die secundären Sexualcharactere. Areh. f. ges. Phys., LXV.

Harris, J. A., A. F. Blakeslee, and W. E. Kirkpatrick, 1918. The eorrelation between egg production during various periods of the year in domestic fowl. Geneties, III.

Hegar, A., 1903. Korrelation der Keimdrüsen und Geschlechtsbestimmung. Beiträge zur Geburtshilfe und Gynäkologic, VII.

Heinroti, O. Von, 1909. Ein lateral hermaphroditisch gefärbter Gimpel (Pyrrhula pyrrhula europaea). Ges. Nat. Freunde zu Berlin.

Herbst, C., 1901. Formative Reize in der tierischen Ontogenese. Leipzig.

Herlitzka, A., 1899. Sul trapiantamento dei testicoli. Areh. f. Ent.-mec., IX.

Holmes, S. J., 1908. Phototaxis in fiddler erabs and its relation to theories of orientation. Journ. Comp. Neurol., XVIII.

Hudson, W. H., 1892. The naturalist in La Plata. London.

HuLL, J. E., 1918. Gynandry in arachnids. Jour. of Geneties, VII.

Hunter, John, 1780. Aecount of an extraordinary pheasant. Phil. Trans. Royal Soc. London., LXX.

Hurst, C. C., 1905. Experiments with poultry. Reports Evol. Committee, II.

Jones, E. L., 1914. The Campine Club, 1914, Year Book (see also Farm Poultry, June, 1914, page 113).

LellogG, V. L., 1904. Influence of the primary reproductive organs on the secondary sexual eharacters. Jour. Exp. Zool., I.

Knappe, E., 1886. Das biddersche Organ. Morph. Jahrb., XI.

KopĔC, S., 1913. Nochmals über die Unabhängigkeit der Ausbildung sekundärer Geschlechtscharaktere von den Gonaden bei Lepidopteren. Zool. Anz., XLIII.

Kurz, W., 1874. Über androgyne Missbildung bei Cladoceren. Sitz. d. math.-nat.-wiss. Klasse. d. Akadem. Wissensel., Wien., LXIX.

Lefevre, G. Sex-limited inheritance in poultry. Anat. Record, XI, p. 499, 1916-17.

Lillie, F. R., 1917. The free-martin; a study of the action of sex-hormones in the foetal life of eattle. Jour Exp. Zool., XXIII.

Lippincott, W. A., 1918. 'The ease of the blue Andalusian. Amer. Nat., LII.

Loewy, A., 1903. Nenere Untersnchungen zur Physiologie der Gesehlechtsorgane. Ergebn. d. Phys. II. Jahrg., I Abt., Biochemie.

LoISEL, 1901. Grenouille femelle presentent toutes les caractères sexuels secondaires du male. Comptes Rend. Soe. Biol.

McEwen, R. S., The reactions to light and to gravity in Drosophila and its mutants. Jour. Exp. Zool., XXV.

Marshall, A. M., 1884. On certain abnormal conditions of the reproductive organs of the frog. Jour. Anat. and Physiol., VIII.

Marshall, F. H. A., 1910. The phsyiology of reproduction. London.

- 1910 . Physiology of Reproduction. New York.

de Meijere, J. C. H., 1911. Über getrennte Vererbung der Gesehlechter. Areh. Rass. Gesell. VIII.

MaYer, A. G., 1897. A new hypothesis of scasonal-dimorphism in Lepidoptera. Psyche, VIII.

- 1900. On the mating instinet in moths. Psyche, IX.

Mazzetti, L., 1916. I Careteri sessuali secondari e le cellule interstitiali del testicolo. Anat. Anz. XXXVIII.

Meisenheimer, J., 1909. Experimentelle Studien zur Soma-und Gesehlechtsdifferenzierung. Jena.

—— - 1911. Über die Wirkung von Hoden- und Ovarial-substanz auf die sekundären Gesehlechtsmerkmale des Frosehes. Zool. Anz., XXXVIII.

Möвıus, P. J., 1906. Über die Wirkungen der Kastration. Halle.

Montgomery, T. H., Jr., 1909. Further studies on the activities of Araneads, II. Proc. Acad. Nat. Sei., Philadelphia. 
Montgomery, T. H., Jr., 1910. The significance of the courtship and secondary sexual characters of Arancads. Amer. Nat., XIIV.

Morgan, T. H., 1905. An alternative interpretation of the origin of gynandromorphous

insects. Science, XXI.
-1907 . Experimental Zoology. New York.

1909. A biological and cytological study of sex determination in phyllox.rans and aphids. Journ. Expr. 'Zool., VII.

1913. Heredity and sex. New York.

—_ 1914. Mosaies and gynandromorphs in Drosophila. Proc. Soc. Biol. and Med., XI.

1914. Sex-limited and sex-linked inheritance. Amer. Natur., Xl,VIII.

1915. Demonstration of the apjearance after castration of cock-feathering in a hen-feathered cockerel. Proc. Soc. Exp. Biol. and Med., XIII.

__ 1917. 'The theory of the gene. Amer. Natur., LI.

__ 1918. A critique of the theory of evo!ution. New York.

- 1 1918. Concerning the mutation theory. Scientific Monthly, May.

- _ - 1918. Changes in factors through selection. Scientific Monthly, June.

__, 1918. Evolution by mutation. Scientific Monthly, July.

Morgan, 'T. H., and H. D. Goodale, 1912. Sex-linked inheritance in poultry. Annals New York Acad. Science, XXII.

Müller, R., 1907. Sexualbiologie. Berlin.

__ - 1908. Dis Problem der sekundären Geschlechtsmerkınale und die Tierzucht.

MYers, B. D., 1916. Histological changes in testes following vasectomy. Anat. Record $\mathrm{X}, 1916$.

Nicholls, F., 1731. An account of the hermaphrodite lobster. Phil. Trans. London, XXXVI.

Nussbaum, M., 1905. Einfluss des Hodensekrets auf die Entwicklung der Brunstorgane des Landfrosches. Verhandl. d. Naturhist. Vereins. f. Rheinl.-lWestfalen, LXII.

_ - 1905. Innere Sekretion und Nerveneinfluss. Ergebn. Anat. und Ent.-ges., XV.

_- 1909. Hoden und Brunstorgane des braunen Landfrosches (Rana fusca). Arch. f. d. gesamte Phys., CXXVI.

Oudemans, H. Th., 1899. Falter aus kastrierten Raupen, wie sie aussehen und wie sie sich benehmen. Zoolog. Jahrb., Abt. Syst., XIII.

Packard, A. S., 1875. On gynandromorphism in the Lepidoptern. Mem. Boston Soc. Nat. Hist., II.

Painter, T. S., 1913. On the dimorphism of the males of Mavia villata, a jumping spider. Zool. Jahrb. Abt., Syst., XXXV.

PeArL, R., and M. R. CurTis, 1909. Studies on the physiology of reproduction in the domestic fowl. Biol. Bull., XVII.

1910. Studies on hybrid poultry. Rept. Maine Agri. Exp. Station.
and F. M. Surface, 1910. On the inheritance of the barred color pattern in poultry. Arch. Ent.-mech., XXX.
, 1910. Further data regarding the sex-limited inheritance of the

- - and F. M. Surface, 1910. On the inheritance of the barred color pattern in barred colored pattern in poultry. Science, XXXII.

__ _ , 1917. The corpus luteum in the ovary of the domestic fowl. Am. Journ. of Anat., XXIII.

Pearse, A. S., 1912. The habits of fiddler crabs. Philippine Journ. Science, V1I.

Pearse, A. 1914. On the habits of Uca pugna and Uca pugilator. Wiscon. Acid. Sci., XVII.

Petrunkewiter, A., 1911. Sense of sight, courtship, and mating in Dugesilla hentai, a theraphosid spider from Texas. Zool. Jahrb., Abst. Syst., XXXI.

Pocock, R. I., 1905. 'The effects of castration on the horns of the prongbuck. Proc. Zool. Soc., London. 
Pols, H., 1909. Zur Lehre von den sekundären Sexualcharakteren. Sitz. Ges. Nat. Fr. zu Berlin.

Poncet, A., 1903. De l'influence de la castration sur le developpement du squelette. Compt. Rend. Soc. Biol., LV.

Porter, J. P., 1906. The habits, instincts and mental powers of spiders. Jour. Phys., XVII.

Pоттs, F. A., 1906. The modification of the sexual characters of the hermit crab caused by the parasite Peltogaster. Q. J. M. Sc., L.

Ponnetr, R. C., 1915. Mimicry in butterflies. Cambridge.

Punnett, R. C., and P. G. Bailey, 1914. On inheritance of weight in poultry. Journ. of Genetics, IV.

RASMUSSEN, A. T., 1917. Scasonal changes in the interstitial cells of the testis in the woodchuck, Marmota monax. Am. Jour. of Anat., XXII.

Reagan, E. P., 1916. Some results and possibilities of early embryonic castration. Anat. Record, II.

Reeves, T. P., 1915. On the presence of interstitial cells in the chicken's testis. Anat. Record, IX, 1915.

Rogen, J., 1909. Kastration und ihre Folgeerscheinungen bei Gryllus campestris L. Zool. Anz., XXXIV.

——, 1910. Kastration und ihre Folgeerscheinungen bei Gryllus campestris L. Zool. Anz., XXXV.

Ribbert, 1897. Ưber Veränderungen transplantierter Gewebe. Arch. f. Ent.-mec., VI. —_, 1898. Úber Transplantation von Ovarium, Hoden und Mamma. Arch. f. Ent. mech., VII.

Romanes, G. J., 1892. Darwin, and after Darwin. Chicago.

Rörig, A., 1899. Welche Bezichungen bestehen zwischen den Reproduktionsorgauen der Cerviden und der Geweihbildung derselben? Arch. Entw.-mech., VIII.

__ - 1901. Korrelationen zwischen gewissen Organen der Cerviden und den Geweihen derselben. Verhandl. internat. Zoolog. Kongress, Berlin.

Shattock, S. G., and C. G. Seligmann, 1906. An example of true hermaphroditism in the domestic fowl with remarks on the phenomenon of allopterotism. Trans. Pathol. Soc. of London.

Saith, Geoffrey, 1910-1912. Studies in the experimental analysis of sex. Q. J. Micro. Sci., LIV-LVIII.

_ - 1913. On the effect of castration on the thumb of the frog, Rana fusca. Zool. Anz., XLI.

Smith, Geoffrey and Mrs. Haig Thomas, 1913. On sterile and hybrid pheasants. Jour. Gen., III.

Spengel, J. W., 1876. Das Urogenitalsystem der Amphibien. Arbeit. Zool. Zootom. in Würzburg, $11 \mathrm{I}$.

Spengel, J. W., 1889. Zwitterbildung bei Amphibien. Biol. Centralbl., IV.

Splllman, W. J., 1908. Spurious allelomorphism. Am. Nat., XLII.

_ 1909 . Barring in barred Plymouth Rocks. Poultry, V.

Stamati, G., 1888. Sur l'opration de la castration chez l'écrevisse. Bull. Soc. Zool. France, XIII.

Steinach, E., 1910. Geschtechtstrieb und echt sekundäre Geschlechtsmerkmale als Folge der innersekretorischen Funktion der Kieimdrüsen. Zeit. f. Phys., XXIV.

1912. Willkürliche Umwandlung von Säugetier-Männchen in Tieren mit ausgeprägt weiblichen Geschlechtscharakteren und weiblicher Psyche. Archiv. ges Phys., CXXXXIIII.

Stephan, P., 1902. De l'hermaphroditisme chez les vertébrés. Annal. de la faculté des sciences de Marseille, XII. 
Stockard, C. R., 1911. The fate of the ovarian tissues when planted on different organs. Arch. f. Ent. Mech., XXXII.

— - and G. N. Papanicolau, 1917. The existence of a typical astrous cyele in the guinea-pig. With a study of its histological and physiological changes. Am. Jour. of Anat., XXII.

Stotsendurg, J. M., 1913. The effeet of spaying and semi-spaying young albino rats (Mus norvegicus albinus) on the growth in body weight and borly length. Anat. Rec., VII.

Sturtevant, A. H., 1911. Another sex-limited character in fowls. Science, XXXIII.

, 1912. An experiment dealing with sex-linkage in fowls. Journ. Exy). Zonl., XII.

1915. Experiments on sex recognition and the problem of sexual selection in Drosophila. Journ. of Animal Behav., V.

Swift, C. H., 1914. Origin and early history of the germ eells of the chick. Amer. Jour. of Anat., XV.

Tandler, J., und K. Kellar. Die Körperform der weibliehen Fruehkastraten des Rindes. Arehiv Entw-mech., XXXI.

und S. Grosz, 1909, 1910. Ueber den Einfluss der Castration auf den Organismus. Arehiv f. Entw-nech., XXVII, XXIX, XXX, 1909.

- _- und S. Grosz, 1913. Die biologischen Grundlagen der sckundären Geschlechtscharaktere. Berlin.

V. LA Valette St. George, 1895. Zwitterbildung beim kleinen Wassermoleh. Arch. Mik. Anat., XLV.

WaLkER, C. E., 1908. The influenee of the testis upon the secondary sexual charaeters of fowls. Proc. Royal Soe. of Med.

Wallace, A. R., 1891. Darwinism: An exposition of the theory' of natural selection. London.

1891. Natural selection and tropical nature. London.

Weber, M., 1890. Über cinen Fall von Hermaphroditismus bei Fringilla coclebs Zool. Anz., XIII.

Yarrell, W., 1827. On the changes in the plumage of some hen-pheasants. Phil. Trans., 117.

1857. On the influence of the sexual organ in modifying external character. Journ. Proc. Linn. Soc., I. 
Plate 1.

FIG. 1. Black-Breasted Game bantam cock. He is typically cock-feathered, but, as in all games, his hackles and tail-coverts are shorter than in the cocks of other breeds. The comb was dubbed by the breeder.

FIG. 2. Black-Breasted Game bantam hen. The great contrast in color between the cock and hen is practically the same as that in the Brown Leghorn, in most races of Tosa fowls, and in the wild type Gallus bankiva.

FIG. 3. Sebright cock, "hen-feathered." The short hackles, the rounded feathers of the back and saddle, and the shortness of the tail-coverts are characteristic features of these males. For details of individual feathers from different regions see plates 6 and 8 .

FIg. 4. A castrated Sebright male. The drawing was made about a year after the operation. This particular bird developed a lighter color than did other castrated Sebrights (see plate 3 , fig. 1). The entire dorsal region has changed its color, and the feathers have also changed in shape, length, etc. Note especially the very long hackle and saddle feathers (for details see plate 6, fig. $1 a$ ) and the change in the wing-bow. The tail-coverts have also grown long.

\section{Plate 2.}

FIG. 1. $F_{1}$ hen-feathered male out of Game by Sebright. The hen-feathering in this bird is as complete as in the Sebright.

FIG. 2. F female out of Game by Sebright.

Fig. 3. Castrated male originally hen-feathered (292), nearly black in color, as shown by the individual feathers of plate 7, figure 2. After castration the bird has become red above, with black iridescent tail-coverts, and deeper yellow (or red) below.

Fig. 4. Castrated $F_{1}$ male, originally like figure 1. Note especially the change in color of the whole upper surface that has become red, like that of the jungle-fowl. The tail-coverts have grown long and are now iridescent black. The breast has changed least, but is a richer yellow. The comb and wattles and ear lobes are shrunken, as in all capons.

\section{Plate 3.}

FIG. 1. A castrated Sebright male. The operation was performed on a juvenile bird; the drawing was made a year later. The bird is typical as to the change in color that takes place in the Sebright. He was darker red than the bird shown in plate 1 , figure 4 . The red was more mahogany than the picture shows. The original feathers were like those in plate 6, fig. 2 (there erroneously referred to as those of light-colored Sebright).

FIG. 2. An $F_{2}$ hen-feathered very dark male. The condition of his plumage at the time of the operation is shown in this figure. The change that took place after castration is shown in the next figure.

Fig. 3. The change that took place in the bird drawn in figure 2 is shown here. The whole upper surface has become red, except the tail-coverts, which are iridescent black. Note also the change in color on the wing-bow. For the details of the feathers see plate 9 , figures $1,1 a$.

Fig. 4. A castrated $F_{2}$ bird that had been hen-feathered and had changed over to cockfeathering, as shown here. The color and the details of the original henfeathering are shown in plate 9 , figures 2 and $2 a$. 
Plate 4.

FIG. 1. One of the original Black-Breasted Game males used in the breeding experiments. Compare with colored drawing, plate 1, figure 1.

FIG. 2. A Black-Breasted Game hen used in the breeling experiments. Compare with colored drawing, plate 1 , figure 2.

FIG. 3. A Sebright male. The bird was used in the later back-crosses and not in the original experiments. He is typical of his breed.

Fig. 4. A Sebright female. One of the birds used in the original experiments.

FIG. 5. An $\mathrm{F}_{1}$ male. This bird had just reached maturity and was younger than the one drawn in plate 2 , figure 1 .

FIG. 6. An $F_{1}$ hen of the same age as the last. The pattern changed a little as the bird became older.

Plate 5.

FIG. 1. An adult Sebright male for comparison with the next figure.

FIG. 2. A castrated Sebright male. This photograph shows the same bird from which the drawing, plate 1, figure 4, was made. It is the lighter colored bird referred to in the text.

Fig. 3. One of the two $F_{1}$ castrated birds. For comparison see the colored drawing in plate 2, figure 4.

Frg. 4. A castrated Sebright. This bird is darker, and in this sense more typical than figure 2 .

FIG. 5. One of the castrated Sebright males which at one time after castration was as extremely cock-feathered as figure 2, but slowly "went back" towards henfeathering, as the figure shows especially in the hackle and saddle. The details are much better shown in the feathers photographed in plate $S$, figures $1,2,3,4,1 a, 2 a, 3 a, 4 a, 1 b, 2 b, 3 b, 4 b$.

Fig. 6. The same bird was opened and the regenerated pieces of the testis remored. He returned later, as shown here, to full cock-feathering.

\section{Plate 6.}

Figs. 1, 1A. Typical old (1) and new (1a) feathers (after castration) of the same bird. This is the "lighter" male drawn in plate 1, figure 4, and photographed in plate 5 , figure 2 .

Figs. 2, 2A. Typical old (2) and new (2a) (after castration) feathers of another Sebright. This bird developed after castration darker feathers than did the last bird. Its feathers were more like those that other castrated Sebrights developed. Legend on plate 6 erroneous as far as 2 and $2 a$ are concerned.

\section{Plate 7.}

Figs. 1, 1A. Typical old (1) and new (1a) (after castration) feathers of an $F_{1}$ bird. (See plate 2, figures 1 and 4.)

FIgs. 2, 2A. Typical old (2) and new (2A) (after castration) feathers of bird shown in plate 3 , figures 2 and 3 (No. 292).

Plate 8.

Typical feathers of "dark" Sebright $(1,2,3,4)$ that after incomplete castration changed to cock-feathering $(1 a, 2 a, 3 a, 4 a)$, then later, as pieces of the testes that had been left behind in the old situs regenerated, began to go back towards henfeathering $(1 b, 2 b, 3 b, 4 b)$. The bird was then opened again, and the regenerated pieces removed, when it again became cock-feathered (1c, 2c, 3c, 4c), and has so remained for more than a year. 


\section{Plate 9.}

Fias. 1, 1A. Typical feathers of hackle and saddle from hen-feathered bird (No. 68) plate 3 , figure 2 , that changed over to the cock-feathered bird of plate 3 , figure 3.

Figs. 2, 2A. Typical feathers of an $F_{1}$ male (2) that changed over partly as a result of degeneration of his testes, into a cock-feathered bird $(2 \mathrm{~A})$. The change was not so great as it is after castration.

Figs. 3, 3A. Typical feathers of Sebright male that slightly changed towards cock-feathering (old hackle feather missing).

\section{Plate 10.}

Figs. 1, 1A. Old (1) and new (1A) wing-coverts of normal Sebright (1) and castrated (1A).

Figs. 2A, 2B. Upper row, to right, "Transitional" hackle feathers (2A), and a slightly later changed-over feather from wing-bow (2A), and from back (2B). Second row, to left, old (2), transitional (2a), and changed-over feather $(2 b)$, from saddle of Sebright.

FIG. 3. Three feathers (tail-covert, wing-bow, and saddle) of an $F_{2}$ hen-feathered game-like male.

Fig. 4. A series of breast feathers from an $F_{2}$ bird. At one end of the series (the left) the feather is spangled, at the other barred.

Fig. 5. A series of breast feathers from another $F_{2}$ bird. At one end of the series (the left) the feathers are penciled, at the other end they are barred. 


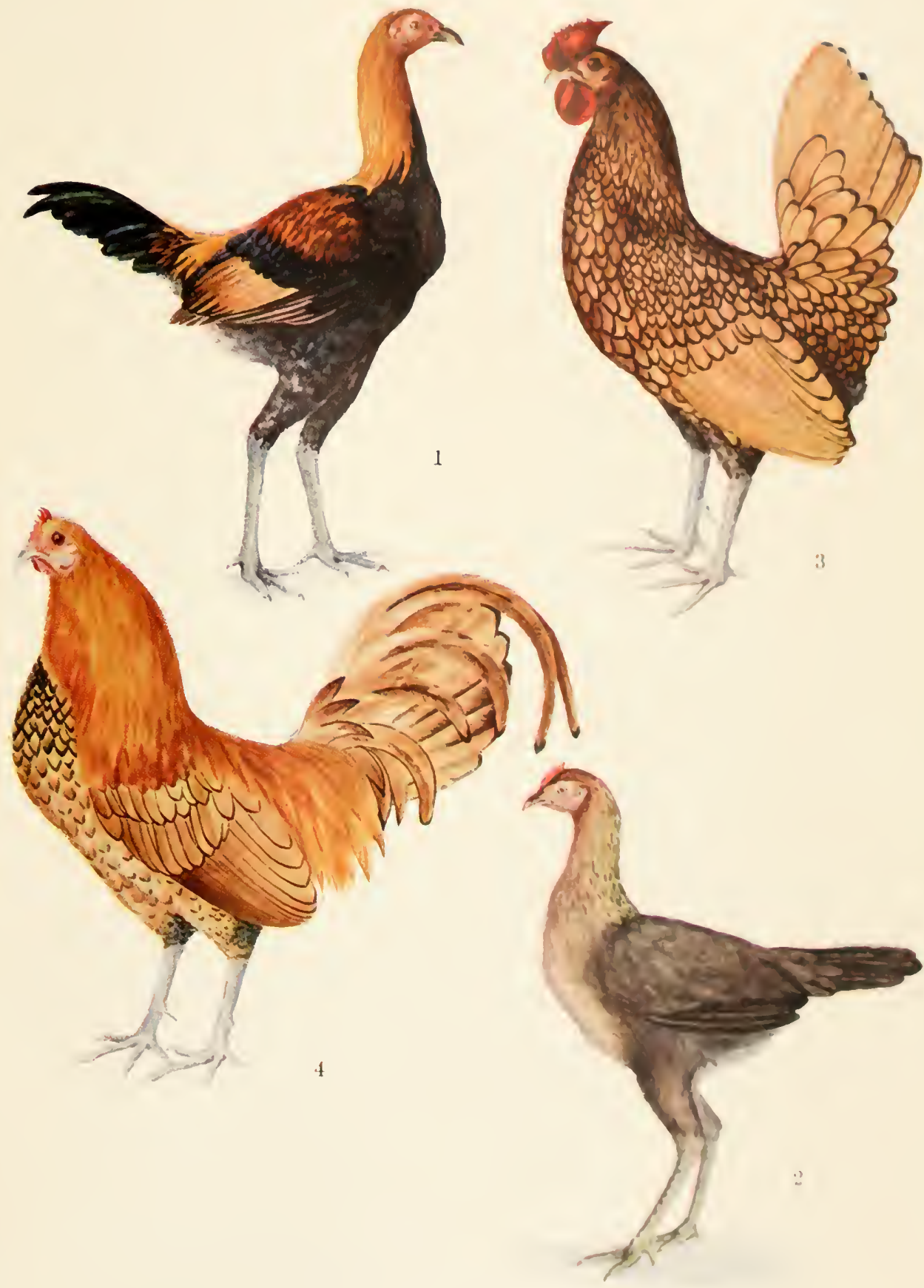




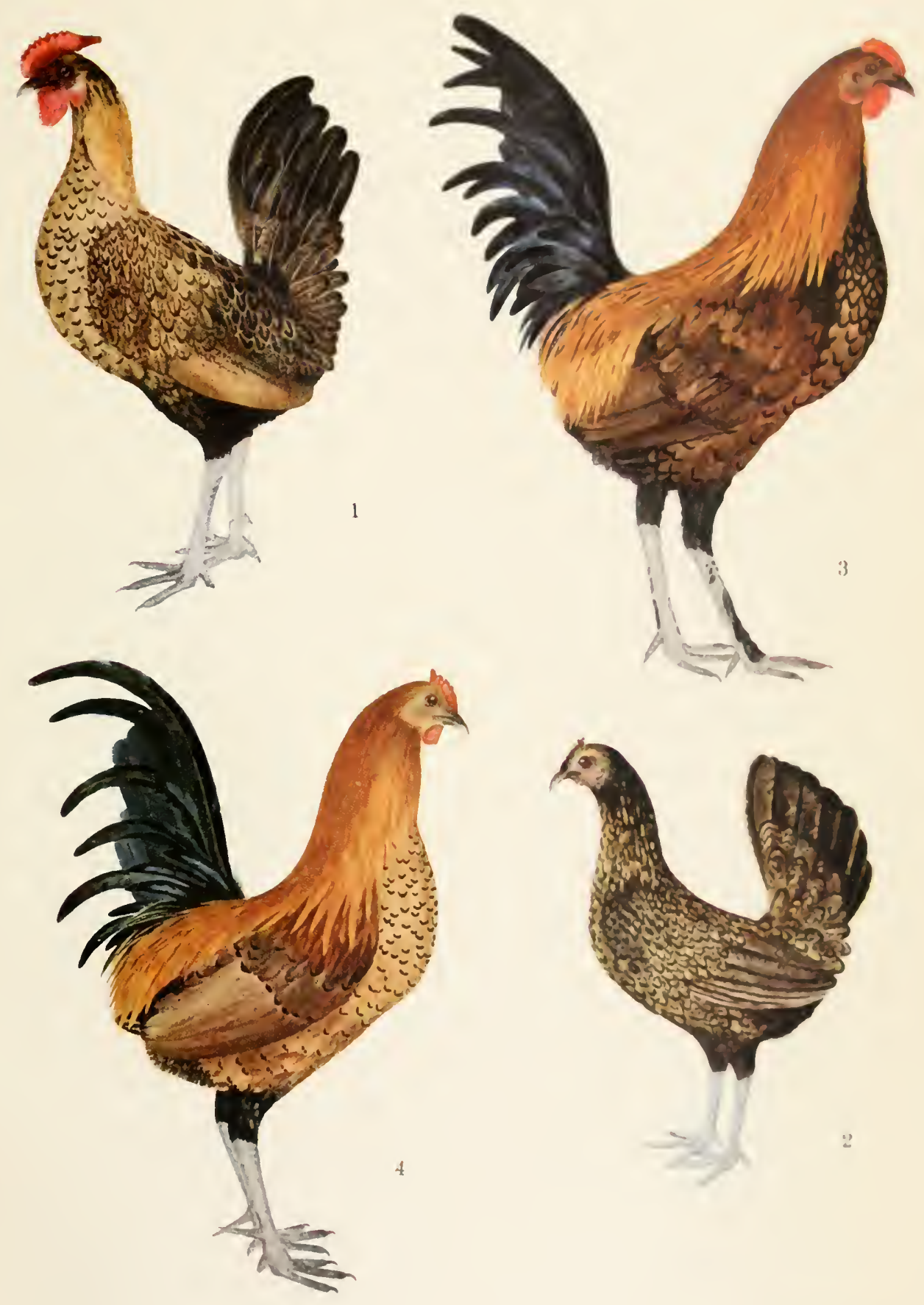

1. IIen-feathered $F_{1}$ malc.

2. $F_{1}$ iemale. 


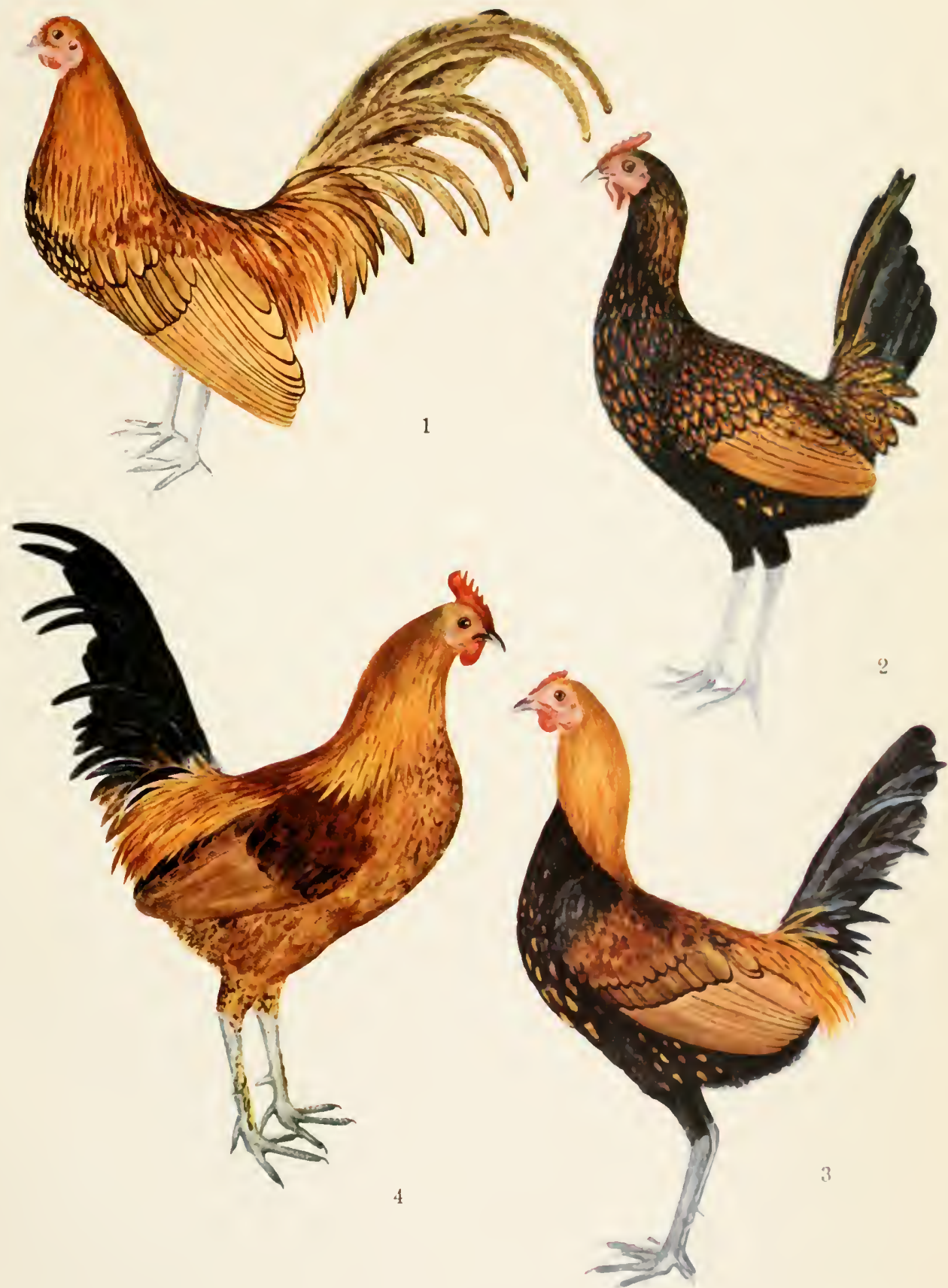

MORGAN
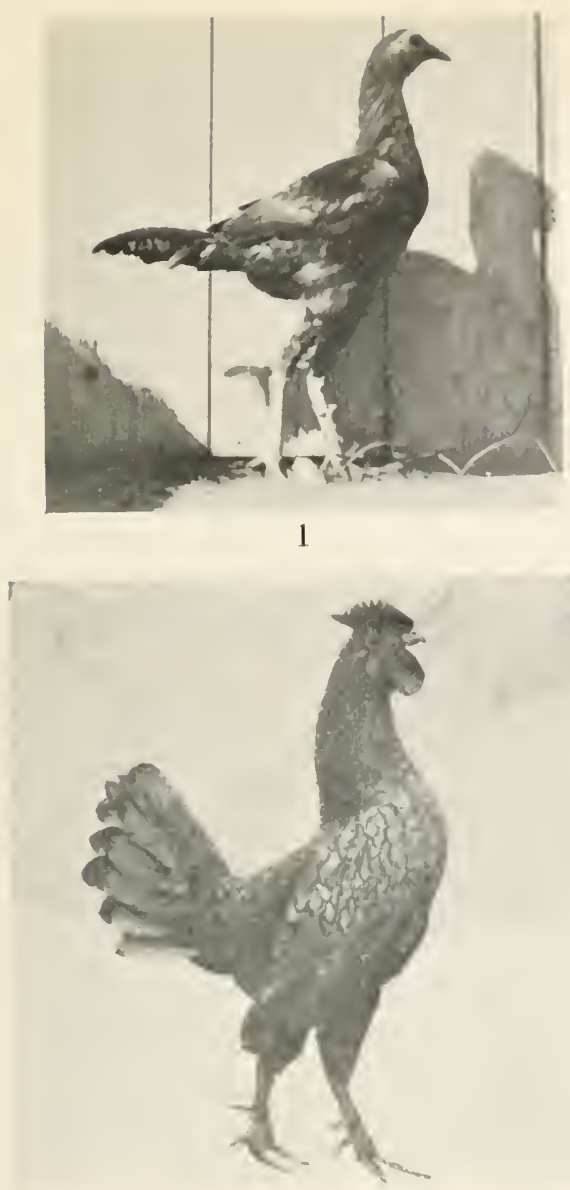

3

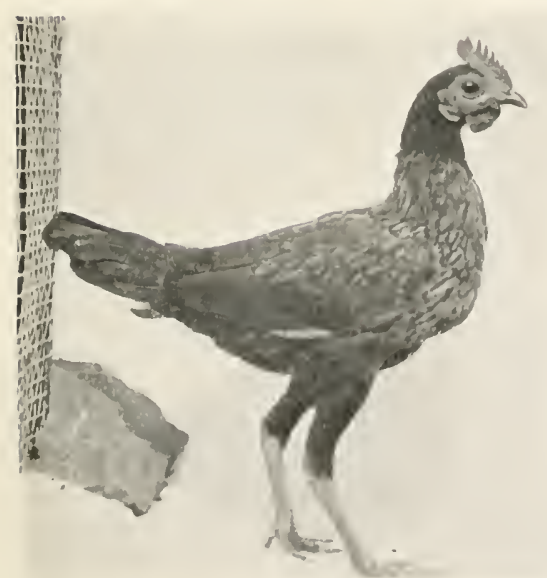

5)

1. Black-Breasted Game male.

3. Sebriglat male.

5. Hybrid male.

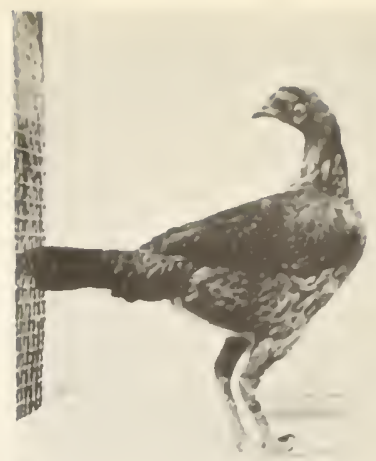

2

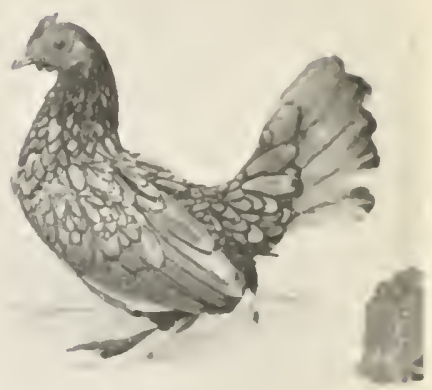

4

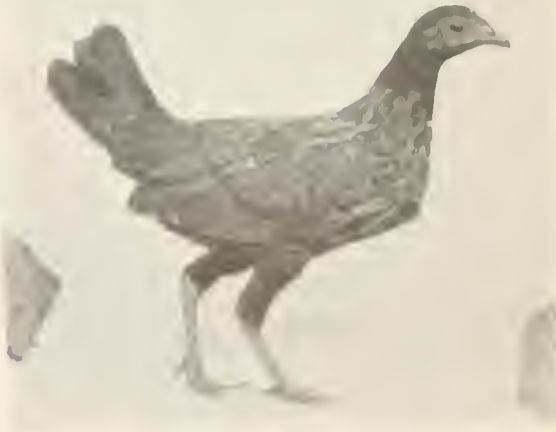

(i)

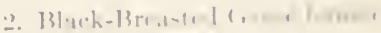

1. Silvight fore de.

i. Hyluril kan. 4 



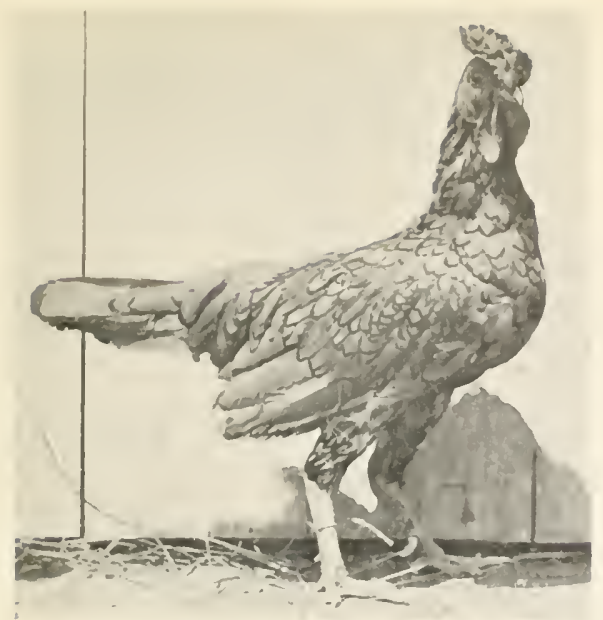

1

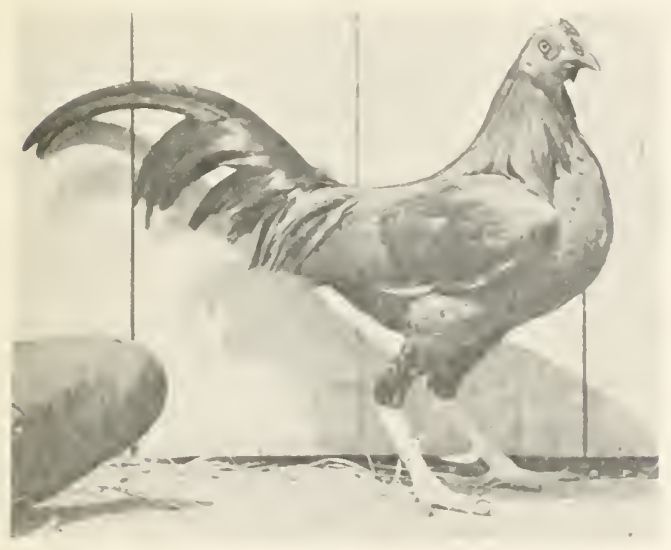

3

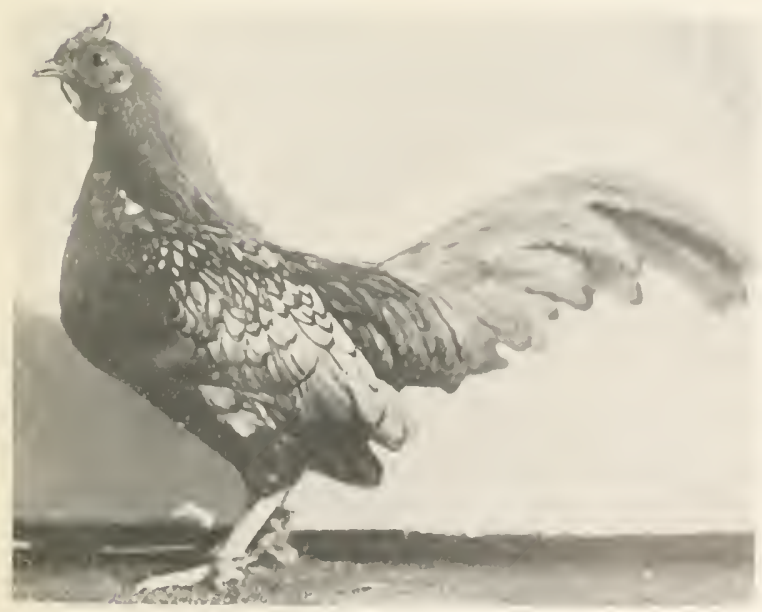

5)

1. Adult seloright male.

3. Castrited Fi male.

5. Castrated solurioht male with testes regenetratine

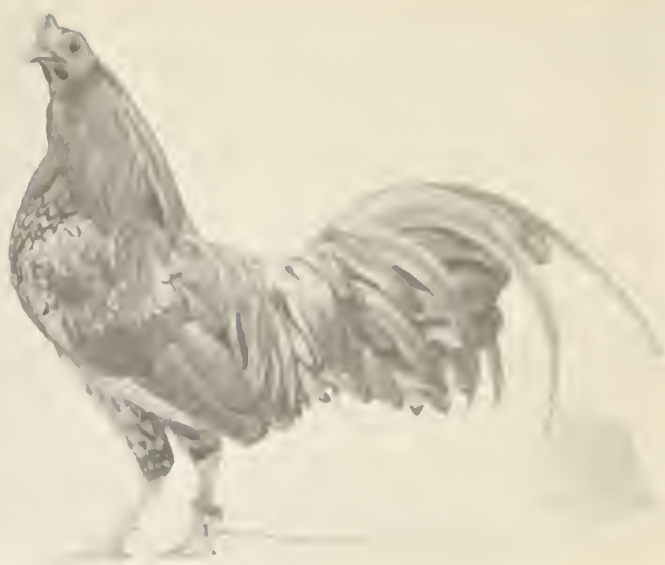

$\underline{2}$

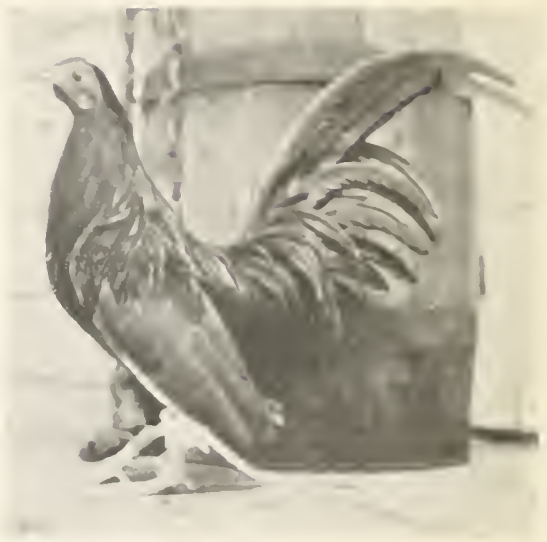

1

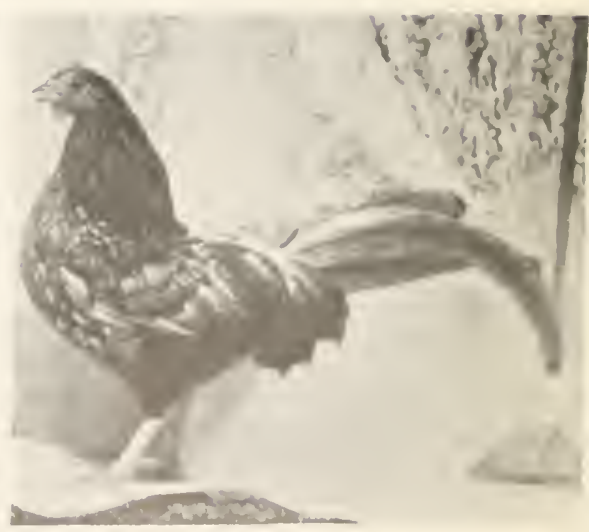

1 i

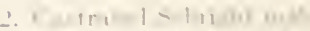

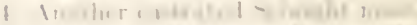

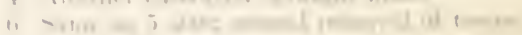





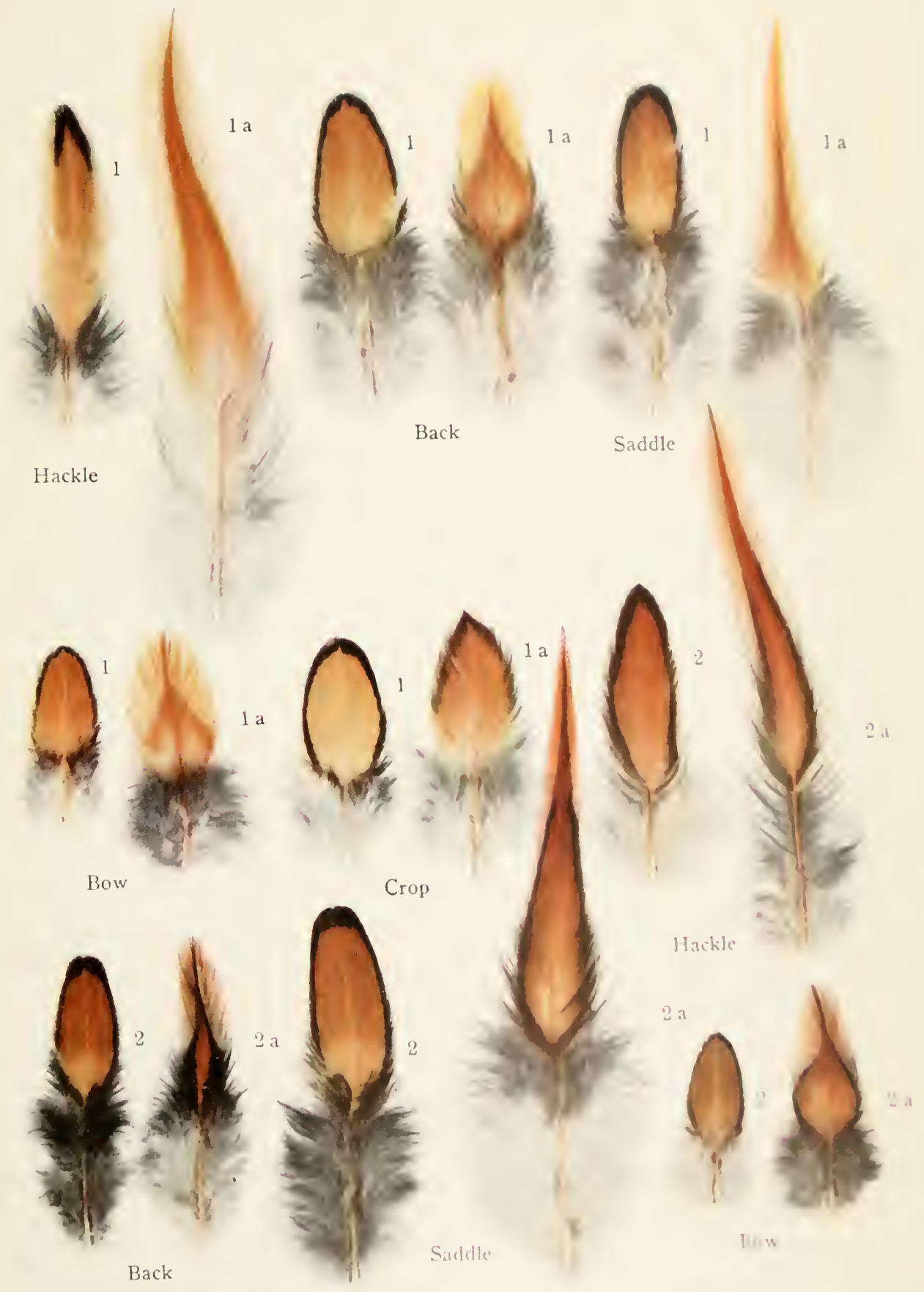

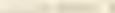

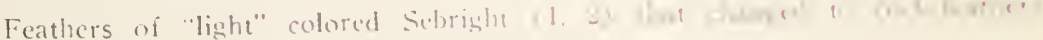
after castration ( $1 \mathrm{a}, 2 \mathrm{2}$ ). 


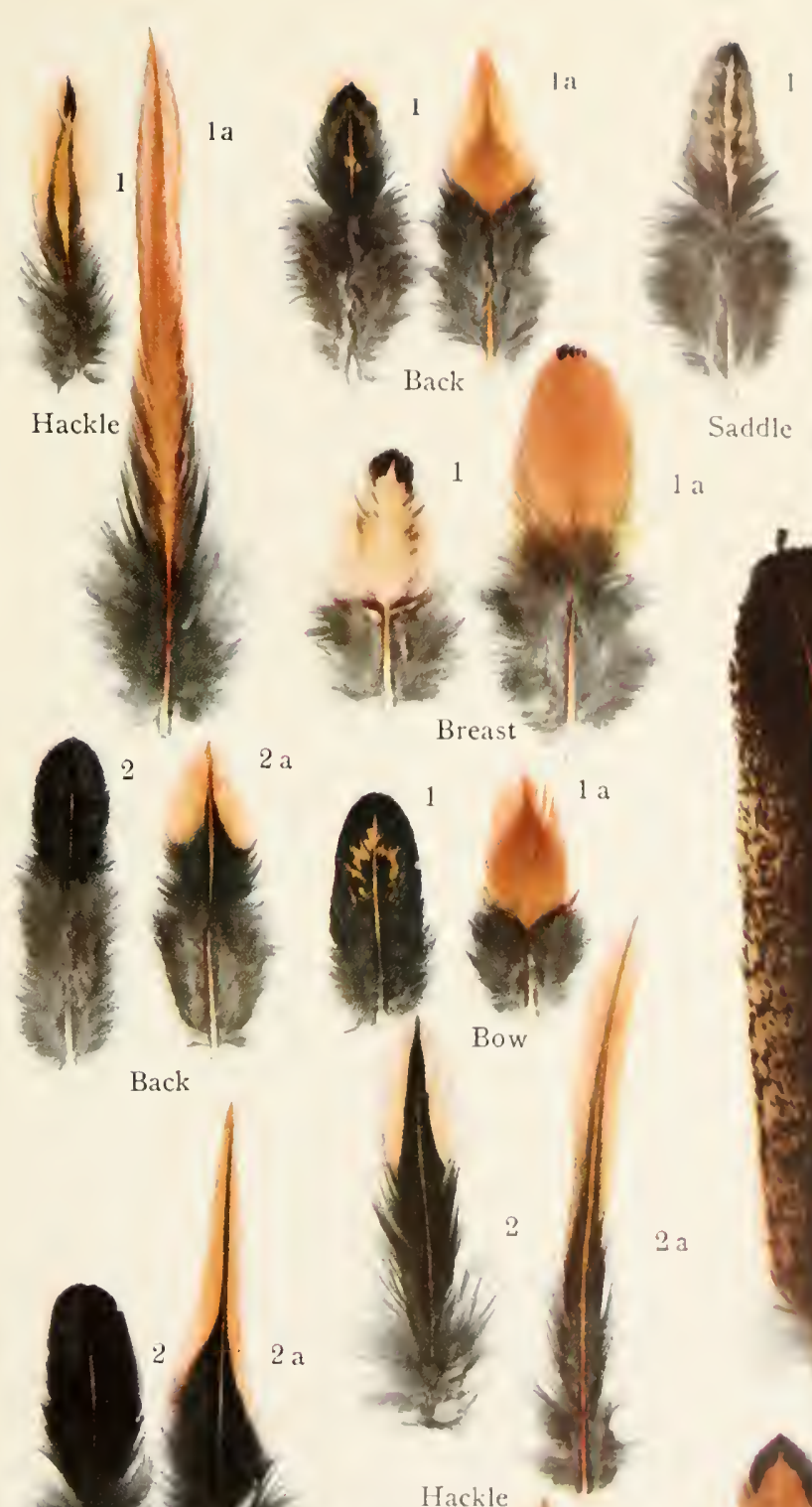

1 a
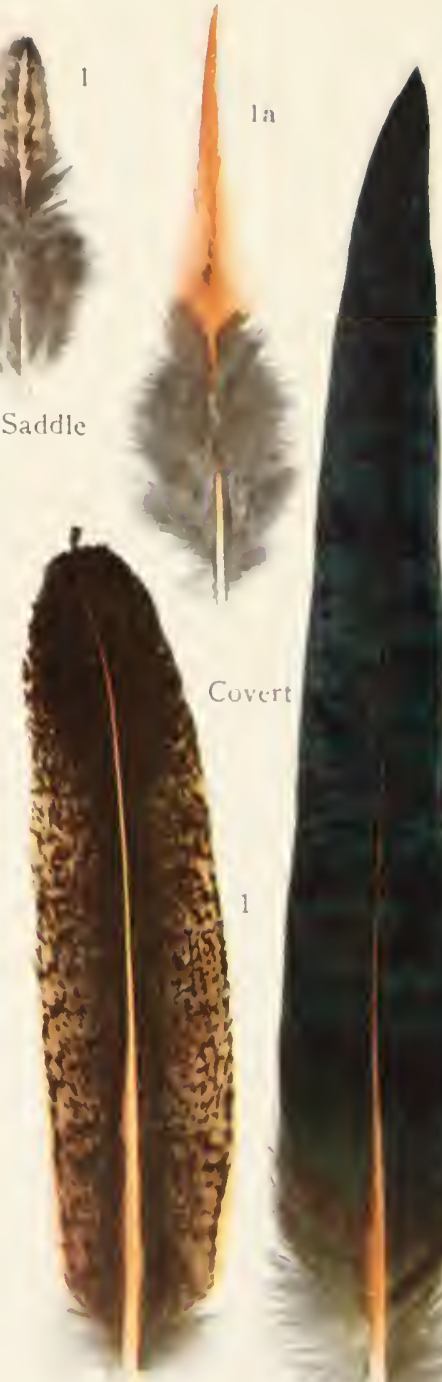

la

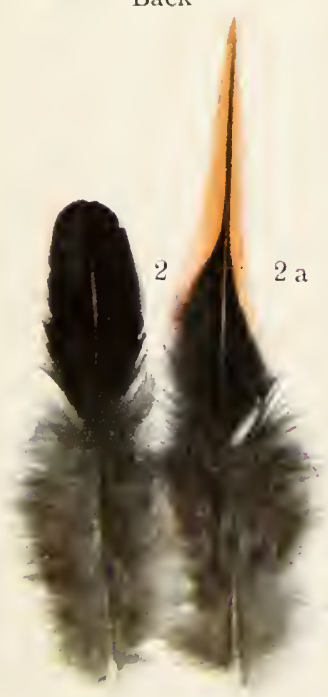

Saddle
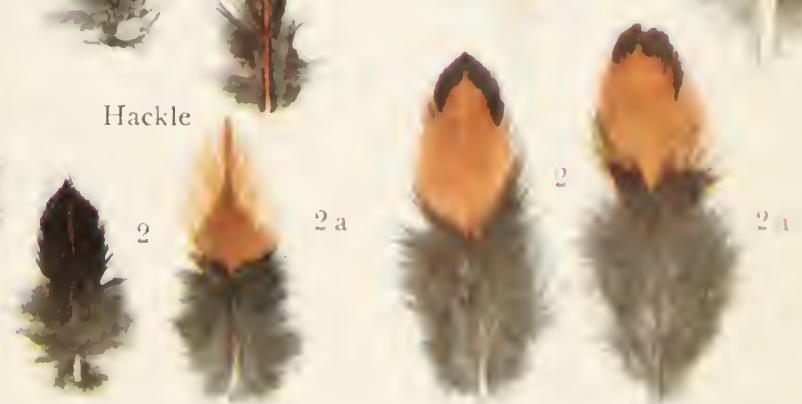

lireise

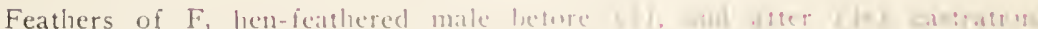

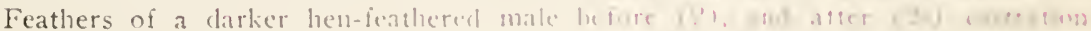





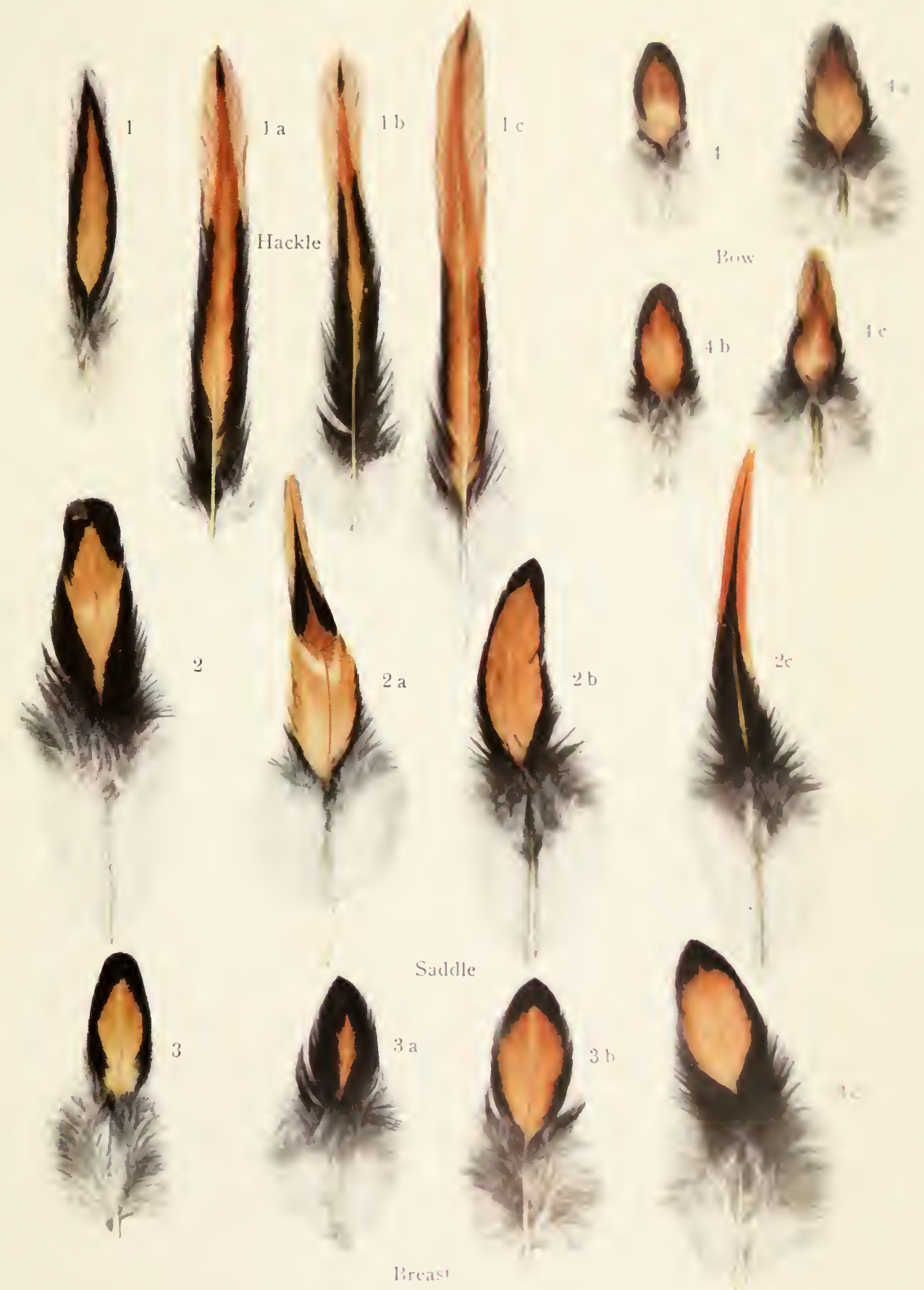

Cont of

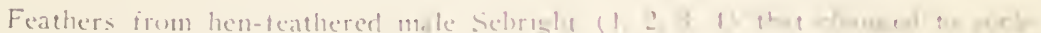

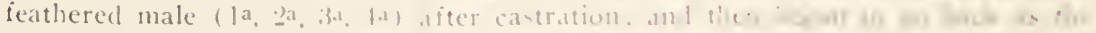

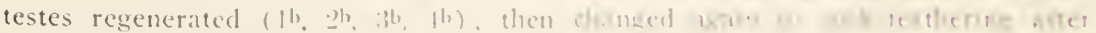
castration ( $1 \mathrm{c}, 2 \mathrm{c}, \mathrm{c}, \mathrm{ic}, \mathrm{dc}$ ) 



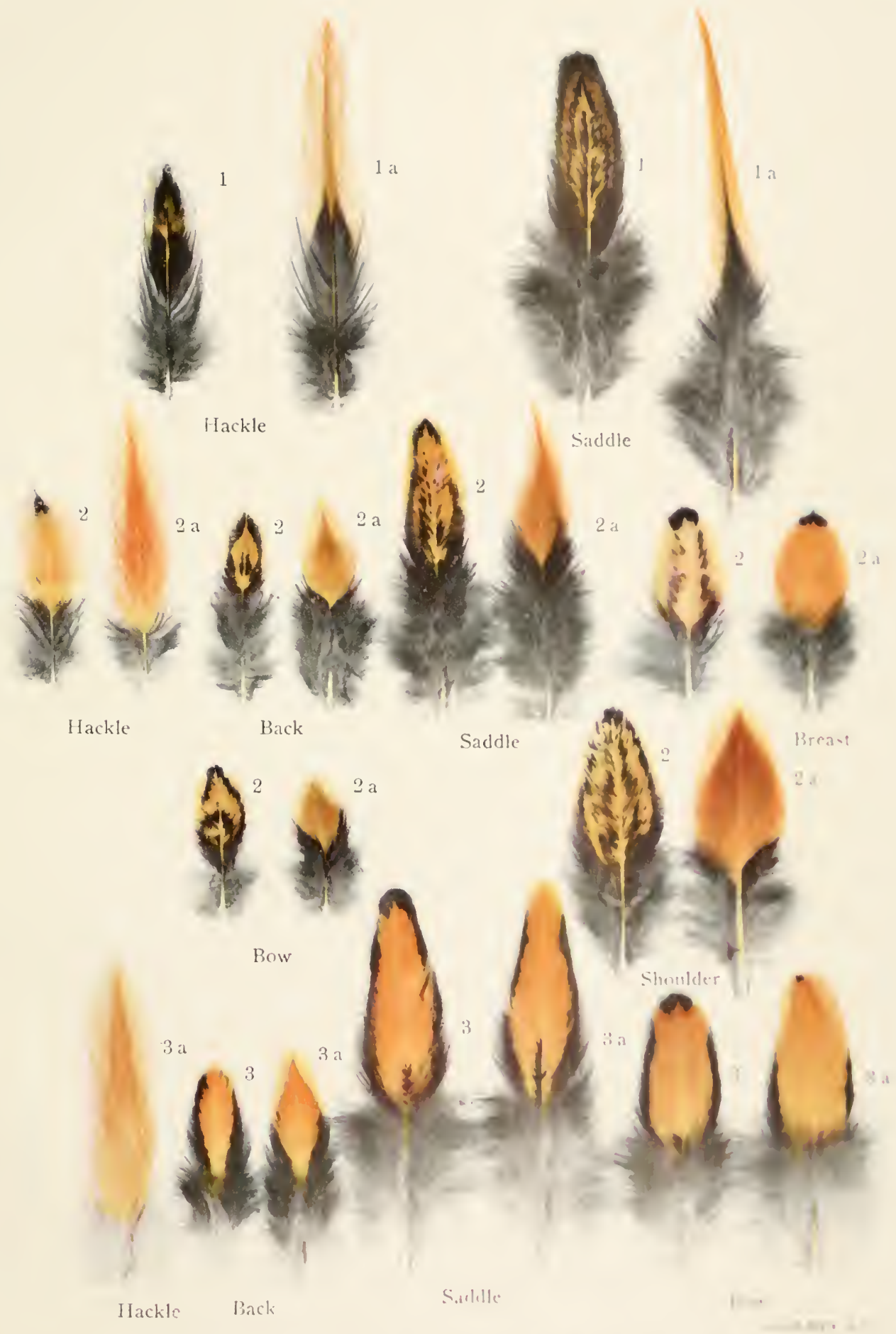

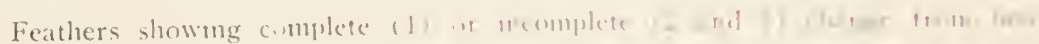

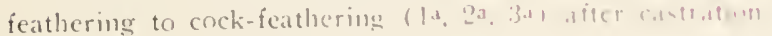




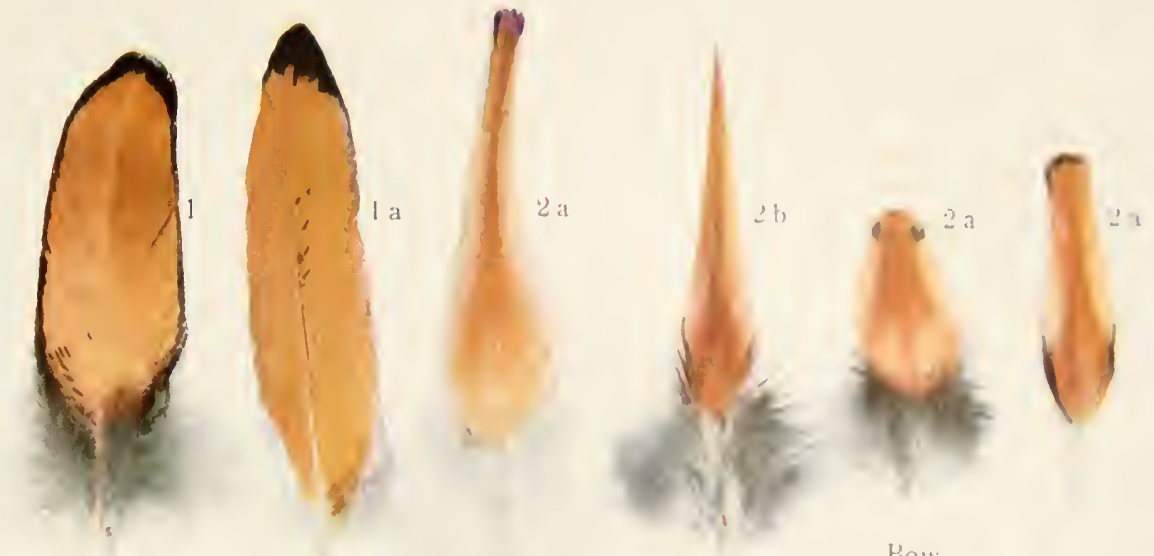

Covert
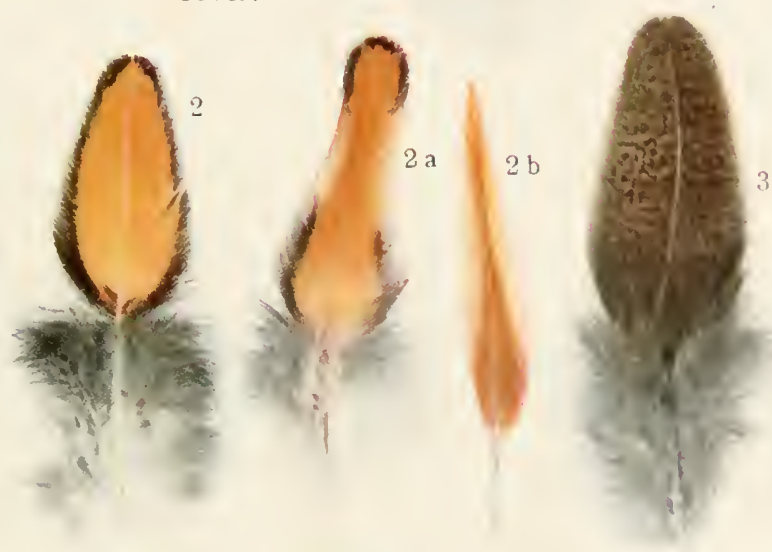

Back
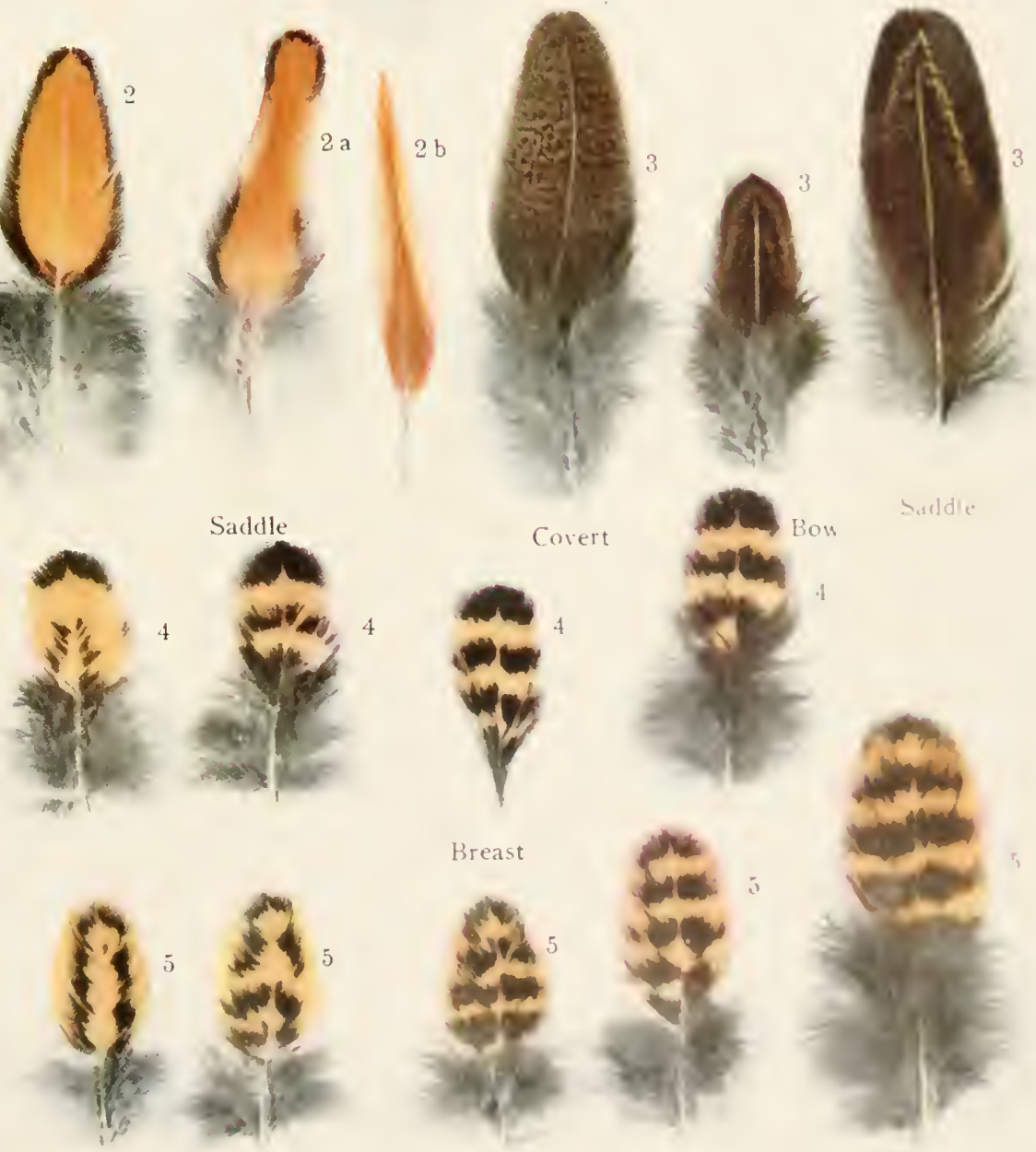

Breast

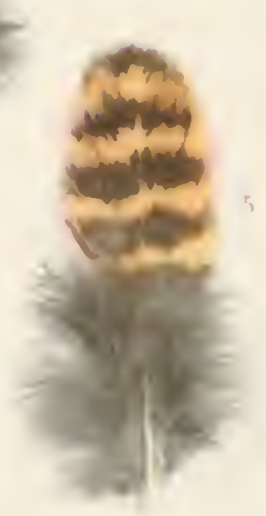

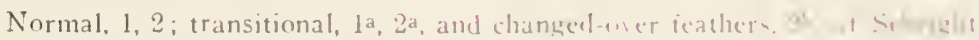

3,4 and 5 . Feathers from $F_{3}$ birds. 
623 BE BR 2518 



$+\frac{10}{20}=$ 